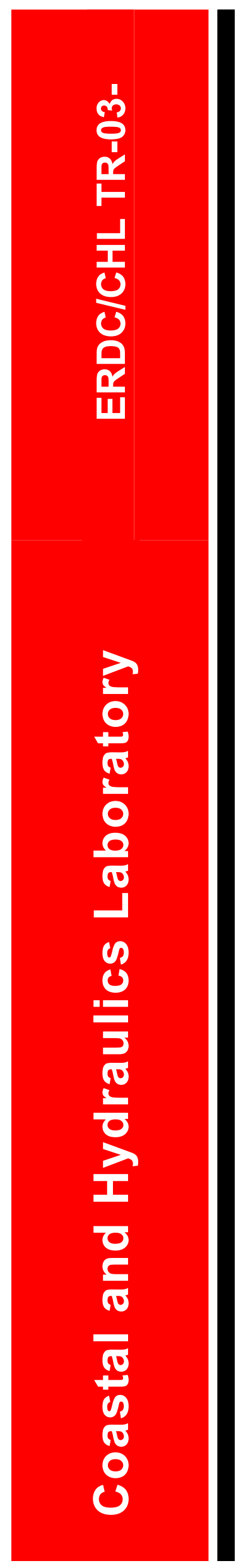

Overtopping Studies of a Stepped Revetment for City of Chicago, Illinois

Donald L. Ward

August 2003

Approved for public release; distribution is unlimited. 

ERDC/CHL TR-03-

August 2003

\section{Overtopping Studies of a Stepped Revetment for City of Chicago, Illinois}

Donald L. Ward

Coastal and Hydraulics Laboratory

U.S. Army Engineer Research and Development Center

3909 Halls Ferry Road

Vicksburg, MS 39180-6199

Final report

Approved for public release; distribution is unlimited.

Prepared for U.S. Army Corps of Engineers

Washington, DC 20314-1000 


\begin{abstract}
Existing stepped-stone revetments along City of Chicago's Lake Michigan shoreline have deteriorated and are in need of replacement. Timber pilings supporting the revetments have decayed and contributed to the collapse of some of the stones in the revetment. The City of Chicago is interested in replacing the stepped-stone revetments with stepped concrete revetments. Physical model experiments were conducted at the U. S. Army Engineer Research and Development Center Coastal and Hydraulics Laboratory to aid in design of the stepped concrete revetment. The physical model experiments measured overtopping rates during design storm events for several proposed designs for the revetment. Parameters of interest included number and size of steps, elevation at crest, elevation at lakeward edge, and width of promenade.
\end{abstract}

DISCLAIMER: The contents of this report are not to be used for advertising, publication, or promotional purposes. Citation of trade names does not constitute an official endorsement or approval of the use of such commercial products. All product names and trademarks cited are the property of their respective owners. The findings of this report are not to be construed as an official Department of the Army position unless so designated by other authorized documents. 


\section{Contents}

Conversion Factors, Non-SI to SI Units of Measurement................................. vii

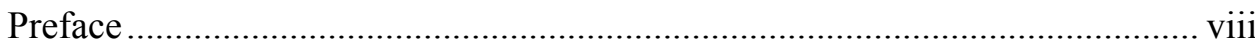

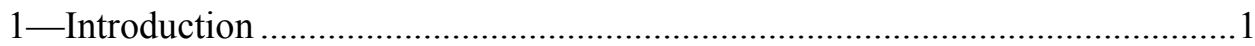

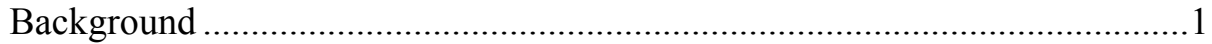

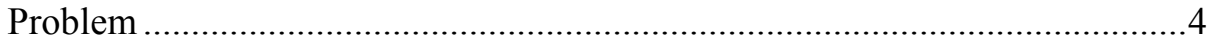

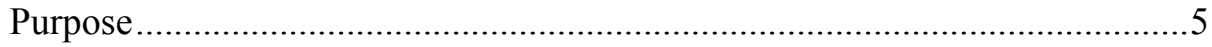

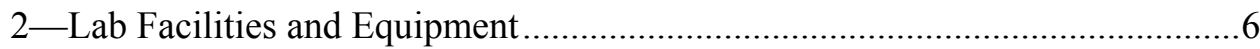

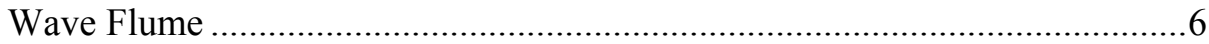

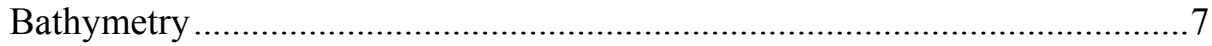

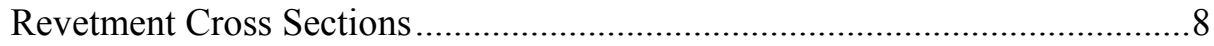

3 - Design Storm Selection, Results and Discussion ........................................ 9

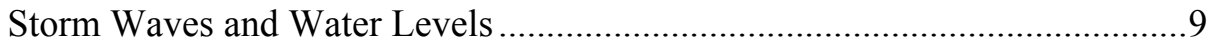

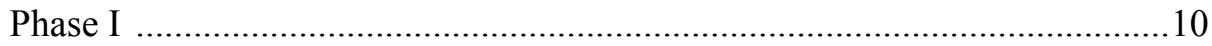

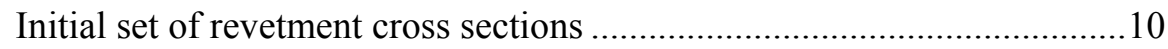

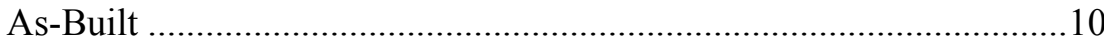

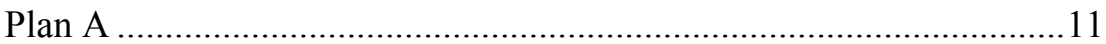

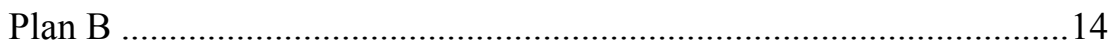

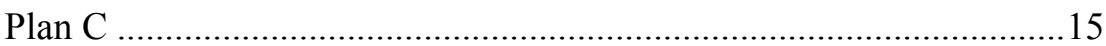

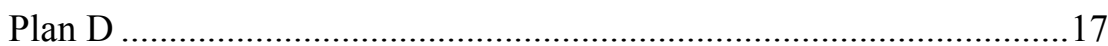

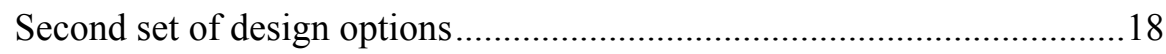

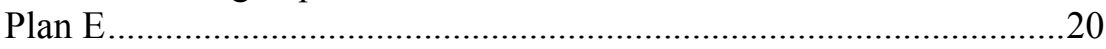

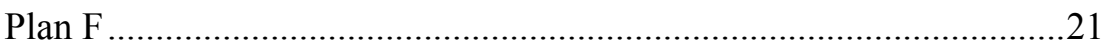

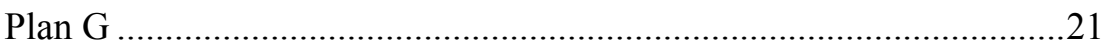

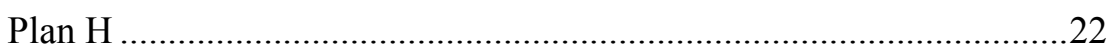

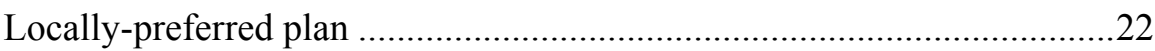

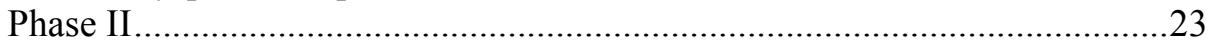

LPP with storm wave height and wave period hydrograph .....................23

Parameter effects on overtopping rate .................................................2

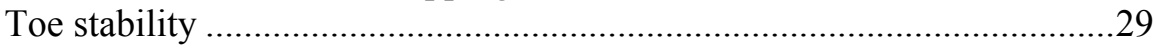

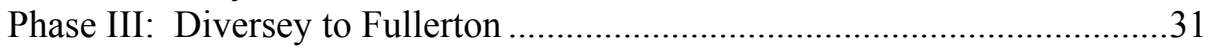

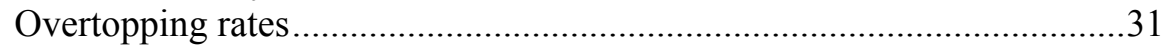

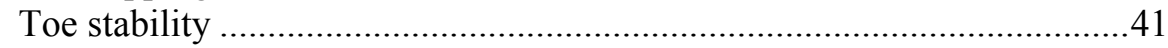

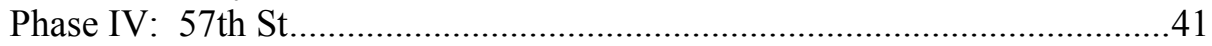

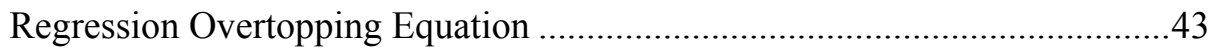

Limitations of Physical Model Studies ...........................................................46 
SF 298

\section{List of Figures}

Figure 1. Project limits for Chicago Shoreline Storm Damage Reduction Project. .

Figure 2. Site location for 26th St. to 33rd St. in Reach 4 (from NOAA Chart 14928)...

Figure 3. Site location for Diversey St. to Fullerton St. (from NOAA Chart 14928)......................................................................

Figure 4. 57th St project site (from NOAA Chart 14927).................................3

Figure 5. Original design of stepped-stone revetment. ....................................4

Figure 6. Cross-section of wave flume.......................................................6

Figure 7. Nearshore bathymetry in wave flume.........................................

Figure 8. Cross-section of "as-built" configuration as reproduced in model ...10

Figure 9. Cross-section of Plan A. .................................................................. 12

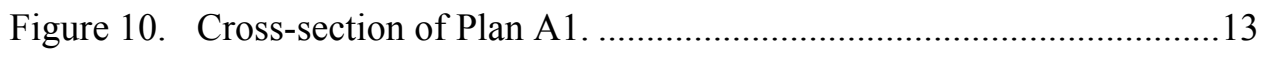

Figure 11. Cross-section of Plan A2 .......................................................... 13

Figure 12. Cross-section of Plan A3 with offshore reef...................................14

Figure 13. Cross-section of Plan A4 with offshore reef and no parapet. ........... 14

Figure 14. Cross-section of Plan A5 with large parapet and offshore reef ........15

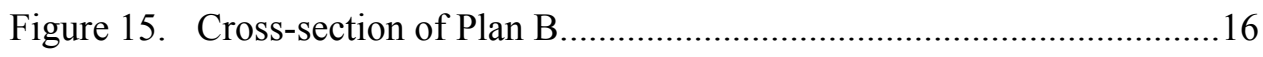

Figure 16. Cross-section of Plan C............................................................... 16

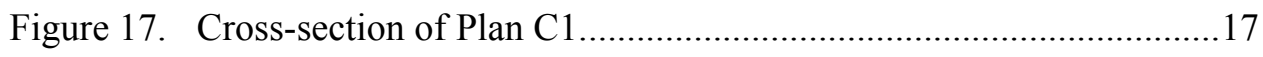

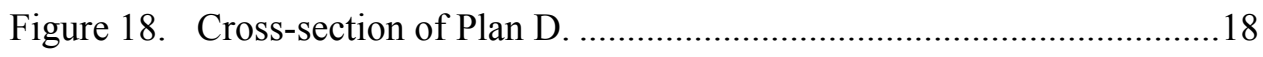

Figure 19. Cross-section of Plan D1 with offshore reef....................................18

Figure 20. Cross-section of Plan D2 ........................................................... 19

Figure 21. Cross-section of Plan D3 with overhang on top step.......................19

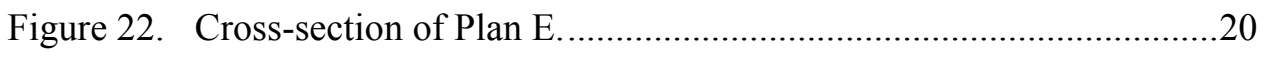

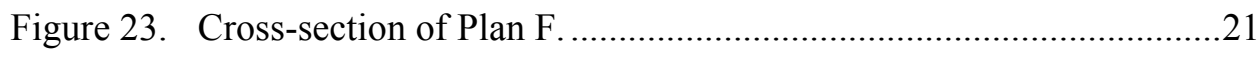

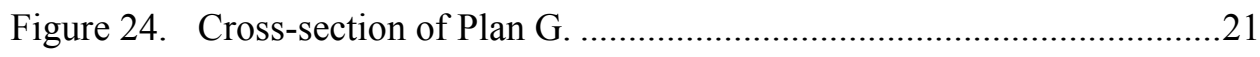

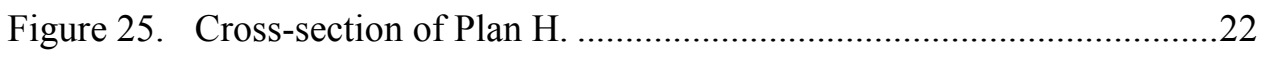

Figure 26. Cross-section of Locally-Preferred Plan..........................................23

Figure 27. Adjusted storm hydrograph for February, 1979, storm ...................24 
Figure 28. Predicted vs measured overtopping rates for Phase II Regression Equation

Figure 29. Cross-section of shallow-water toe protection.................................29

Figure 30. Cross-section of deeper-water toe protection ..................................30

Figure 31. Cross-section of Plan A with toe berms............................................32

Figure 32. Cross-section of Plan 1 Tests 1 through 6 .......................................35

Figure 33. Cross-section of Plan 2 Tests 1 through 4 ......................................35

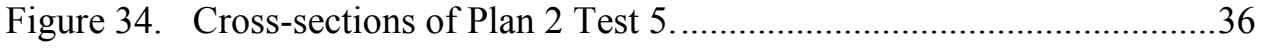

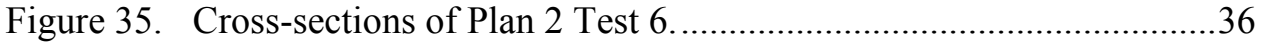

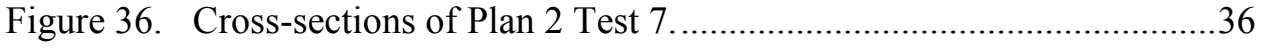

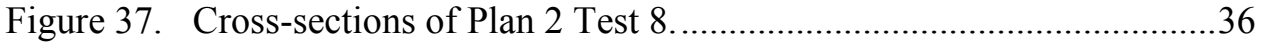

Figure 38. Cross-sections of Plan 2 Test 9......................................................

Figure 39. Cross-sections of Plan 2 Test 10..................................................

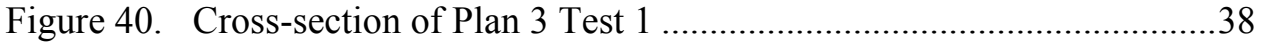

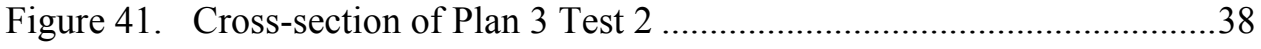

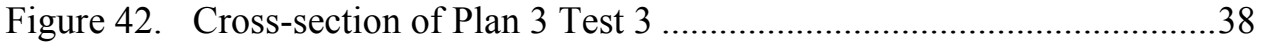

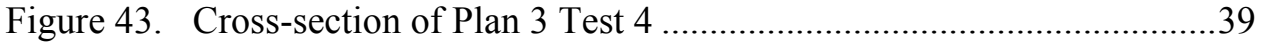

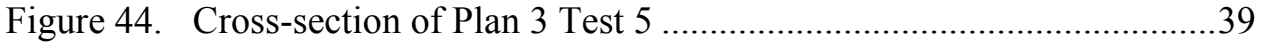

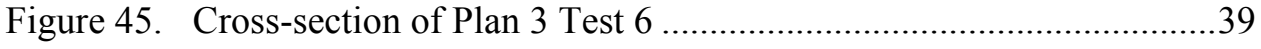

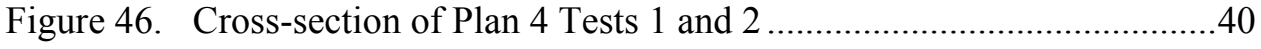

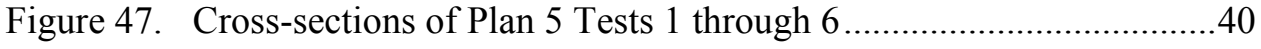

Figure 48. Cross-section of Plan 1 Tests 7 (toe berm at -5.0) and 8 (toe berm at -7.0) ...................................................................4

Figure 49. Cross-sections of 57th St. revetments ...........................................42

Figure 50. Predicted vs measured overtopping rates.......................................45

\section{List of Tables}

Table 1. 10- and 20-year Storm Waves and Water Levels. ............................. 9

Table 2. Overtopping Rates (Prototype) for the As-Built Structure and Plans A, B, C, and D..........................................................11

Table 3. Overtopping Rates (Prototype) for Modifications to

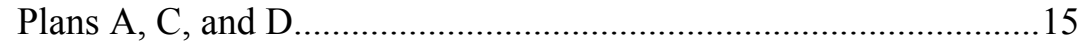

Table 4. Overtopping Rates (Prototype) for Plans E, F, G, and H..................20 
Table 5. Selected Design Storm Hydrograph Wave Heights and

Periods Adjusted to 10-year Design Storm.

Table 6. Overtopping Rates (Prototype) for the Locally Preferred

Plan with Sheetpile Toe at $-2.29 \mathrm{~m}(-7.5 \mathrm{ft})$. .26

Table 7. Overtopping Rates (Prototype) for the Locally-Preferred Plan with Sheetpile Toe at $-5.03 \mathrm{~m}(-16.5 \mathrm{ft})$. .26

Table 8. Regression Coefficients with Standard Error and 95 Percent

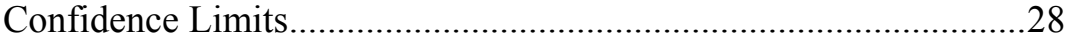

Table 9. Range of Parameters in LPP Storm Regression Equation ................28

Table 10. Overtopping Rates for Phase III Experiments with Promenade Elevation at $+1.83 \mathrm{~m}(+6.0 \mathrm{ft})$ and Revetment Toe Elevation at $-5.03 \mathrm{~m}(-16.5 \mathrm{ft})$ (Depths are LWD)....................33

Table 11. Bathymetry in Vicinity of 57 th St...................................................42

Table 12. Overtopping Rates (Prototype) for 57th St. Revetment ....................43

Table 13. Regression Coefficients with Standard Error and 95 Percent

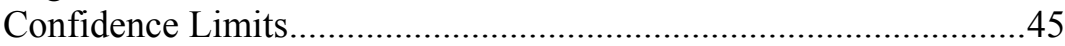

Table 14 Ranges of Parameters Used in Equation 18 ….................................46 


\section{Conversion Factors Non-SI to SI Units of Measurement}

Non-SI units of measurement used in this report can be converted to SI units as follows:

\begin{tabular}{|l|l|l||}
\hline \hline Multiply & By & To Obtain \\
\hline \hline feet & 0.3048 & meters \\
\hline cubic feet & 0.02831685 & cubic meters \\
\hline square feet & 0.09290304 & square meters \\
\hline & & \\
\hline
\end{tabular}




\section{Preface}

This study was authorized by U.S. Army Engineer District, Chicago, and was conducted by personnel of the U.S. Army Engineer Engineering Research and Development Center's (ERDC's) Coastal and Hydraulics Laboratory (CHL). Phases I and II of the study were conducted during the period June, 1997 to July, 1998. Point of contact (POC) at the Chicago District for Phases I and II was Ms. Mary K. Tibbetts. Phases III and IV of the study were conducted during the period March 2001 to October 2001. POC at the Chicago District for Phases III and IV was Mr. James G. Mazanec.

Phases I and II of the physical model study were conducted by personnel of the Coastal Structures Branch (CN-S) of the Coastal Navigation and Harbors Division (CN) CHL, under the direction of Dr. James R. Houston and Mr. Charles C. Calhoun, former Director and former Assistant Director, CHL, respectively, Messrs. C. Eugene Chatham, Jr., Chief, CN, and D. D. Davidson, Chief, CN-S. Mr. Willie Dubose, Engineering Technician, CN-S, and Dr. Donald Ward, research hydraulic engineer, CN-S, constructed the models used in the study and conducted the experiments in the wave flume. Phases III and IV of the physical model study were conducted by personnel of the Coastal Harbors and Structures Branch (HC-P) under the direction of Mr. Thomas W. Richardson, Director, CHL, and Mr. Dennis G. Markle, Chief, HC-P. Messrs. Dubose and Raymond Reed, engineering technicians, HC-P, and Dr. Ward, HC-P, constructed the models used in the study and conducted the experiments in the wave flume. Dr. Ward analyzed the data and prepared this report.

Dr. James R. Houston was Director of ERDC and COL James R. Rowan, EN, was Commander and Executive Director. 


\section{Introduction}

\section{Background}

The Chicago Shoreline Storm Damage Reduction Project lies along the Lake Michigan shoreline. It extends through the City of Chicago from the town of Evanston, IL, on the north to the Indiana state border on the south, a distance of about $45 \mathrm{~km}$ (28 mi) (Figure 1). The northern portion of Reach 4 of the project is located on the south side of Chicago, and extends approximately from $26^{\text {th }}$ Street to $33^{\text {rd }}$ Street (Figure 2). The Reach 4 shoreline was created by an extensive landfill project conducted in the 1920's and 1930's. Phases I and II of this study were developed for the Reach 4 shoreline. Phase III of this study was developed for the area between Diversey and Fullerton Streets (Figure 3), and Phase IV was developed for an area near $57^{\text {th }}$ Street (Figure 4).

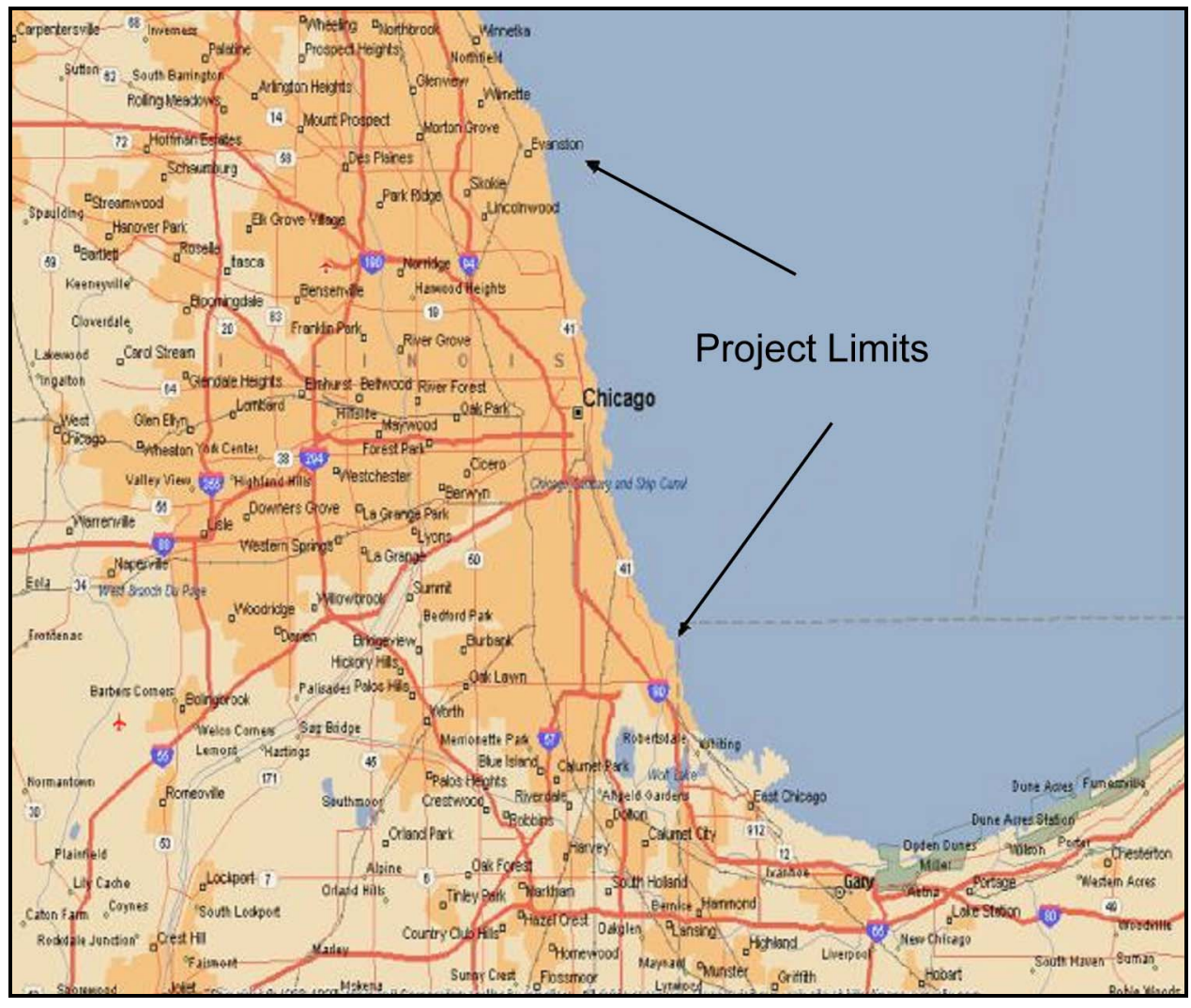

Figure 1. Project limits for Chicago Shoreline Storm Damage Reduction Project 


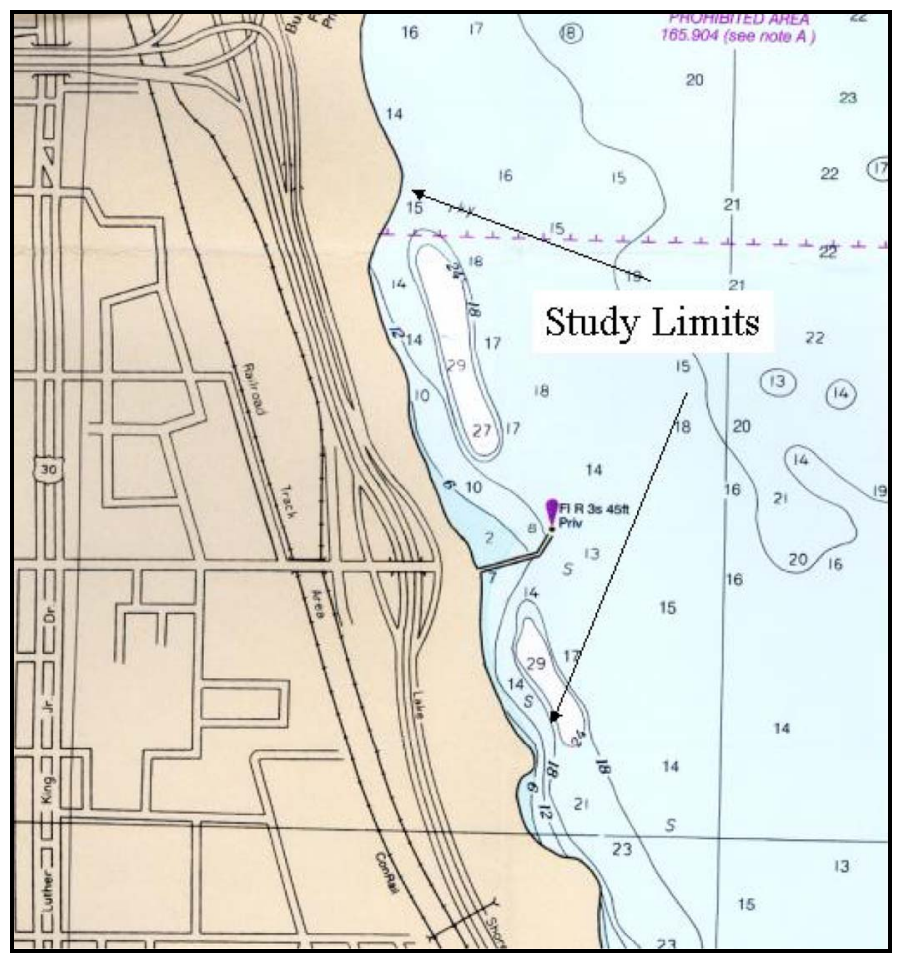

Figure 2. Site location for 26th St. to 33rd St. in Reach 4 (from NOAA Chart 14928)

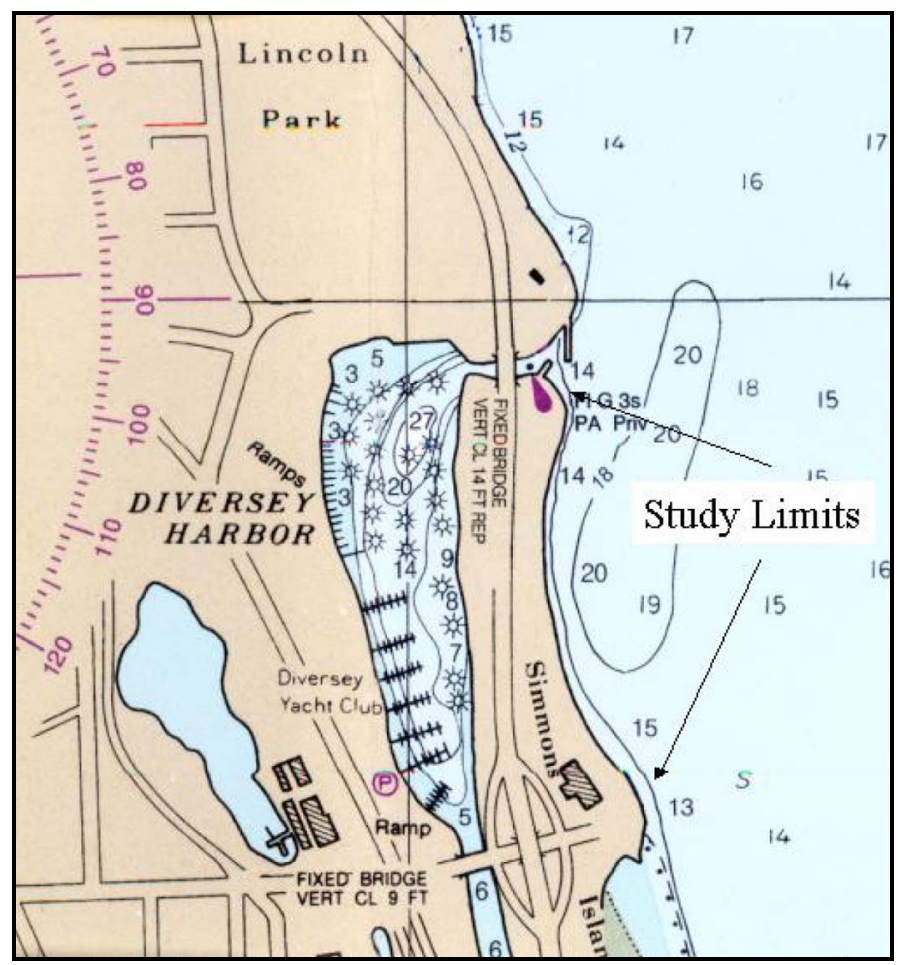

Figure 3. Site location for Diversey St. to Fullerton St. (from NOAA Chart 14928) 


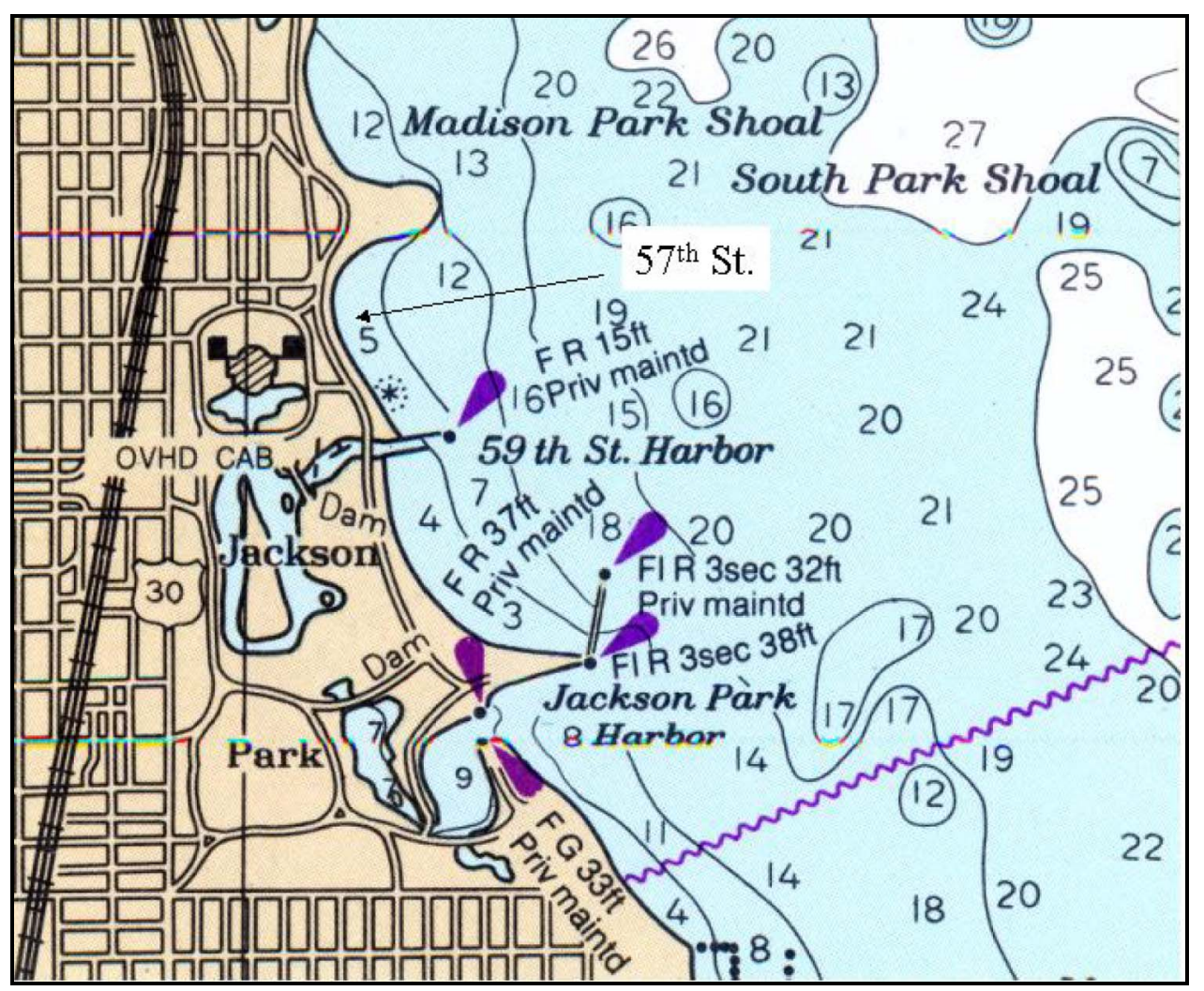

Figure 4. 57th St. project site (from NOAA Chart 14927)

The landfill project was protected by stepped-stone revetments consisting of a timber-pile wall with quarry-run backfill, topped with large shaped stone grouted together to form a series of steps. Figure 5 shows a typical cross-section of the stepped-stone revetment with elevations referenced to low water datum (LWD). The steps are very popular for sun bathing or just relaxing along the lakefront.

When water levels in Lake Michigan dropped significantly, the exposed timber piles rotted and failed. As the backfill was released through the failed pilings, the large shaped stones forming the steps collapsed into the voids left by the backfill. At the present time, much of the stepped-stone revetment has either failed or is in need of repair.

The Chicago shoreline is prone to flooding during storm events, with floods inundating parklands and closing down Lake Shore Drive (US Highway 41), a major thoroughfare. The deteriorated condition of the stepped-stone revetment fronting Reach 4 has exacerbated the flooding and has caused further degradation of the revetment.

The portion of the Chicago Shoreline Storm Damage Reduction project that is federally supported through the National Economic Development plan consists of a low-crest, wide berm rubble-mound revetment. The rubble-mound revetment, however, does not offer the recreational benefits of the stepped revetment. Local 


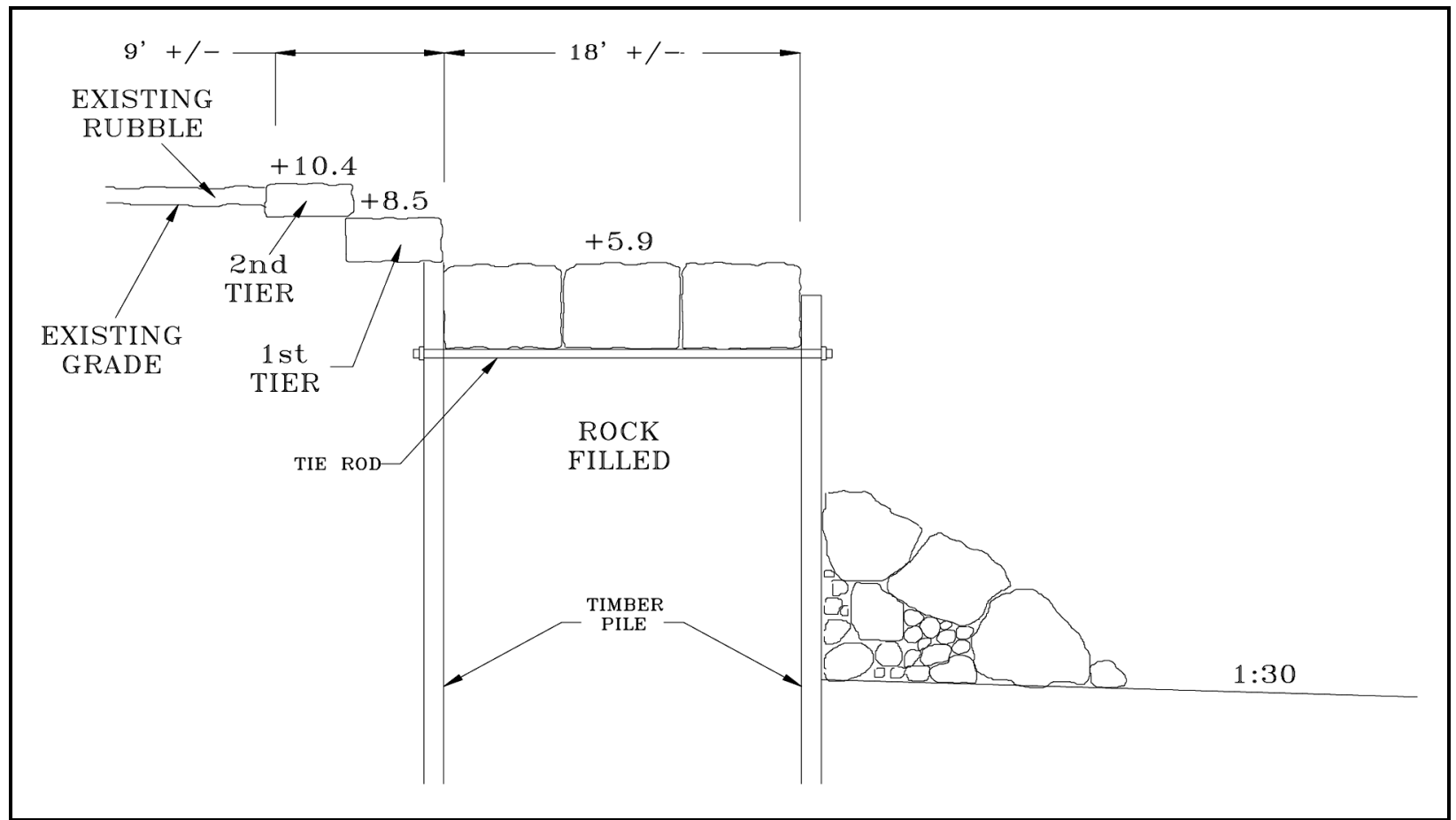

Figure 5. Original design of stepped-stone revetment

sponsors of the project (City of Chicago and Chicago Park District) have elected to rebuild the revetment with a steel-sheetpile structure topped with a concretestepped revetment.

The 1996 Water Resources Development Act (Public Law 104-303) authorized the Chicago Shoreline Storm Damage Reduction and Shoreline Erosion Protection project.

Total cost of the project is currently estimated at \$269 million, of which $\$ 144$ million is Federal cost and $\$ 125$ million is non-Federal cost. Benefit/cost ratio is estimated at 5.5 .

\section{Problem}

Design optimization of the new stepped revetment required that overtopping rates be determined for various structure configurations under consideration. Overtopping of the revetment would be allowed during design storm events, but the amount of overtopping should not exceed the ponding capacity (plus the return flow) of the parkland adjacent to the revetment. The stepped revetment is very site-specific and there are no equations or design curves available to determine overtopping rates for different crest elevations of the steps, step widths and heights, promenade widths, and crest elevations of the sheetpile wall. Design of the rubble toe protection also required study. A physical model study was therefore required to measure overtopping rates for different structural configurations during design storm conditions, measure overtopping rates for the 
selected configuration for a range of storm conditions, and examine the stability of different rubble toe protection measures.

\section{Purpose}

The purpose of this investigation was to determine overtopping rates for several selected structural configurations, which would aid Chicago District, City of Chicago and Chicago Park District in selecting the preferred configuration. Overtopping rates for the selected configuration would then be determined for a range of storm conditions from which the Chicago District could estimate stormduration overtopping and flooding for storms with various return periods and lake levels. 


\section{Lab Facilities and Equipment}

\section{Wave Flume}

The physical model study was conducted at the US Army Engineer Research and Development Center Coastal and Hydraulics Laboratory (CHL) in Vicksburg, MS.

All tests were conducted in a glass-walled flume, 45.7-m long by 0.91-m deep and $0.46-\mathrm{m}$ wide ( $150 \mathrm{ft}$ by $3.0 \mathrm{ft}$ by $1.5 \mathrm{ft}$ ) equipped with a computer-controlled, electro-hydraulic piston-type wave generator (Figure 6). During Phase I and II of this study, wave generator control, data acquisition, and data analysis were all conducted using software developed at CHL. During Phase III and IV of this study, wave generator control and data acquisition and analysis were carried out with a newly acquired data acquisition and control system.

Based on Froude model law, the model was built at an undistorted linear scale of 1:35 (model:prototype), which was determined to be the largest scale for which the wave generator could reproduce the desired wave spectra. All dimensions and results in this report are presented in prototype scale with all elevations referenced to LWD unless otherwise noted.

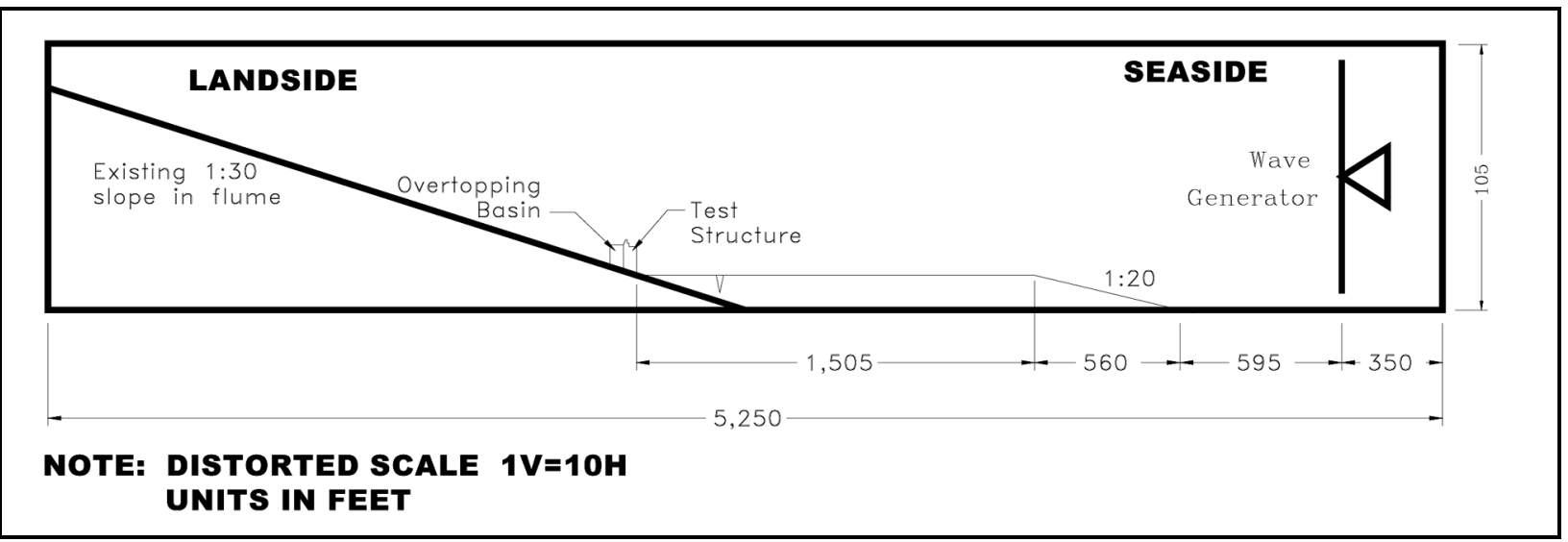

Figure 6. Cross-section of wave flume 


\section{Bathymetry}

Figure 2 depicts a section from a National Oceanographic and Atmospheric Administration (NOAA) chart showing bathymetry in the area modeled during Phase I and II of the study. Several depressions exist offshore from the project limits. These depressions are borrow pits dredged to provide material for highway construction projects. Effects of these borrow pits on overtopping of the revetment was not known, therefore it was decided to conduct a series of experiments both with and without the borrow pits. A false bottom was installed above the permanent flume floor to allow for the increased depth at the borrow pit. A cover was built for the borrow pit so that the flume could be run either with the borrow pit in place or with a cover to provide a flat bottom lakeward of the test structure (Figure 7).

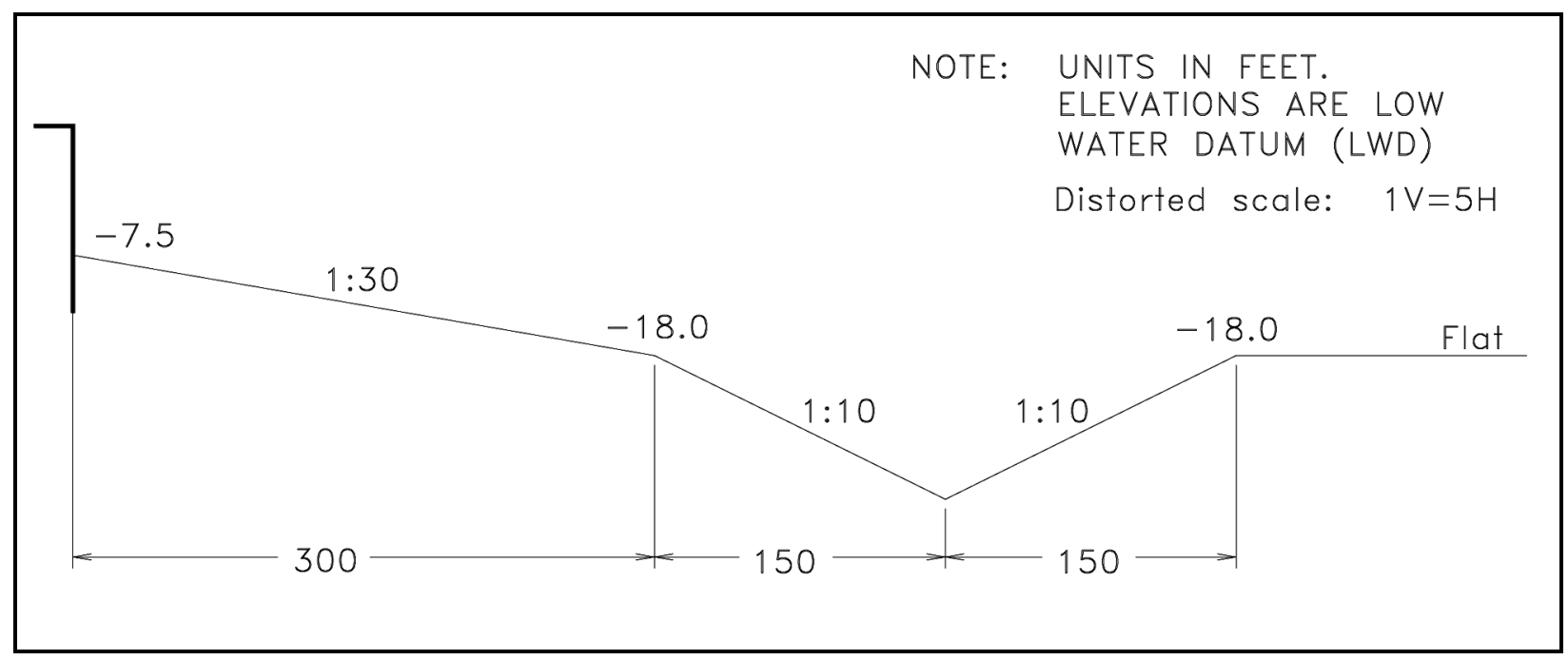

Figure 7. Nearshore bathymetry in wave flume

Depth at the revetment toe varies substantially along the section of Reach 4 selected for testing in Phase I and II (see Figure 2). At the request of LRC, experiments were conducted with depth at the revetment toe of $-2.29 \mathrm{~m}(-7.5 \mathrm{ft})$ and $-5.03 \mathrm{~m}(-16.5 \mathrm{ft})$. With the bathymetry in place for the deeper of the two toe depths, a second slope was designed to overlay the deeper slope and provide for a shallower toe depth while maintaining the same offshore bathymetry.

The bathymetry installed in the flume was as follows. Flume bottom was at -14.6-m (-48 ft). A 1:20 (V:H) slope was installed starting $256 \mathrm{~m}(840 \mathrm{ft})$ in front of the wave board to an elevation of $-5.5 \mathrm{~m}(-18 \mathrm{ft})$. A flat false bottom at $5.5 \mathrm{~m}(-18 \mathrm{ft})$ extended from the slope for a distance of $274 \mathrm{~m}(900 \mathrm{ft})$. The borrow pit was modeled with 1:10 side slopes to a depth of $-10.1 \mathrm{~m}(-33 \mathrm{ft})$, then immediately sloped back up to the $-5.5-\mathrm{m}$ depth $(-18 \mathrm{ft})$ also with a 1:10 slope. For the deepwater revetment toe, the bottom continued shoreward at $-5.5 \mathrm{~m} \mathrm{(-18}$ $\mathrm{ft}$ ) for an additional $69 \mathrm{~m}$, then sloped upwards at a 1:50 slope to the revetment toe at $-5.0 \mathrm{~m}(-16.5 \mathrm{ft})$. For the shallow water revetment toe, a 1:30 slope was installed from the shoreward side of the borrow pit to intercept the revetment at - 
$2.3 \mathrm{~m}(-7.5 \mathrm{ft})$. A cross-section of the bathymetry as installed in the wave flume is shown in Figure 6. A cross-section of the nearshore bathymetry for the shallow water toe is shown in Figure 7.

\section{Revetment Cross Sections}

Revetment cross-sections were constructed of marine plywood and sealed to the sides of the flume. A ramp was placed landward of each cross-section such that all water overtopping the structure would flow into the overtopping collection basin from where it was pumped into a measurement basin and then returned to the flume. 


\section{Design Storm Selection, Results and Discussion}

\section{Storm Waves and Water Levels}

Overtopping rates for coastal structures are closely correlated with water level and incident wave height and period. For the Chicago Lakefront Project, LRC elected to select the design storm from overtopping rates produced by a combination of 10-year and 20-year storm waves (storms having the statistical probability of being equaled or exceeded once every 10 or 20 years, respectively) with the 10-year or 20-year water levels. Wave height and period for the 10 -year and 20-year storms and the 10- and 20-year water levels were provided by LRC and are listed in Table 1. Wave heights and periods for the 10- and 20-year storms were based on wave hindcast information at a 13-m (43-ft) depth.

\begin{tabular}{|c|c|c|c|}
\hline \multicolumn{4}{|c|}{$\begin{array}{l}\text { Table } 1 \\
\text { 10- and } 20 \text {-year Storm Waves and Water Levels }\end{array}$} \\
\hline Return Period & $\begin{array}{l}\text { Water Level } \\
\mathrm{m}(\mathrm{ft})\end{array}$ & $\begin{array}{l}\begin{array}{l}\text { Wave Height } \\
\mathrm{H}_{0}, \mathrm{~m}(\mathrm{ft})\end{array} \\
\end{array}$ & $\begin{array}{l}\text { Wave Period } \\
\mathrm{T} \text {, sec }\end{array}$ \\
\hline 10-year & $+1.65(+5.4)$ & $5.60(18.4)$ & 12.4 \\
\hline 20-year & $+1.80(+5.9)$ & $6.00(19.7)$ & 12.8 \\
\hline
\end{tabular}

Depth in the wave flume immediately in front of the wave generator during Phases I, II, and III of this study was $14.6 \mathrm{~m} \mathrm{(48ft),} \mathrm{which} \mathrm{compared} \mathrm{favorably}$ with the wave hindcast depth plus storm surge indicated by the water levels in Table 1. For purposes of this study, storm waves were generated using the Joint North Sea Wave Project (JONSWAP) spectrum (Hasselmann et al. 1973 ${ }^{1}$ ) using the hindcast wave height, $\mathrm{H}_{\mathrm{o}}$, as the spectral zeroth-moment wave height, $\mathrm{H}_{\mathrm{m} 0}$, and the hindcast wave period as the period of peak energy density, $T_{p}$. Similarly, for storms with a given significant wave height, $\mathrm{H}_{\mathrm{s}}$, storms were generated using $\mathrm{H}_{\mathrm{s}}$ as the $\mathrm{H}_{\mathrm{m} 0}$ for generation of storm waves.

\footnotetext{
${ }^{1}$ Hasselmann, K., Barnett, T. P., Bouws, E., Carlso, H., Cartwright, D. C., Enke, K., Ewing, J., Gienapp, H., Hasselmann, D. E., Sell, W., and Walden, H., " Measurements of Wind-Wave Growth and Swell Decay During the Joint Sea Wave Project (JONSWAP)," Deutshes Hydrographisches Institut, Hamburg, 1973.
} 


\section{Phase I}

\section{Initial set of revetment cross sections}

Overtopping rates on the first set of structure cross-sections ("as-built" design plus Plans A, B, C, and D) were determined for all combinations of 10-year and 20 -year water level, and 10-year and 20-year storm waves. Measured overtopping rates are listed in Table 2 and descriptions of the revetment crosssections are given below.

As-Built. Overtopping rates were measured on a model of the original structure cross-section (undamaged) of the stepped-stone revetment to establish a baseline for comparing overtopping rates obtained with different configurations of the revetment. The "as-built" configuration included a vertical wall to an elevation of $+1.95 \mathrm{~m}(+6.4 \mathrm{ft})$, a 6.1 -m-wide (20-ft-wide) promenade sloping to an elevation of $+2.26 \mathrm{~m}(+7.4 \mathrm{ft})$, and two 1.07 -m-wide (3.5-ft-wide) steps with the first step at an elevation of $+3.78 \mathrm{~m}(+12.4 \mathrm{ft})$ and the second step at an elevation of $+4.39 \mathrm{~m}(+14.4 \mathrm{ft})$ (Figure 8$)$. No attempt was made to model the stone core of the revetment or the deteriorated condition of portions of the revetment.

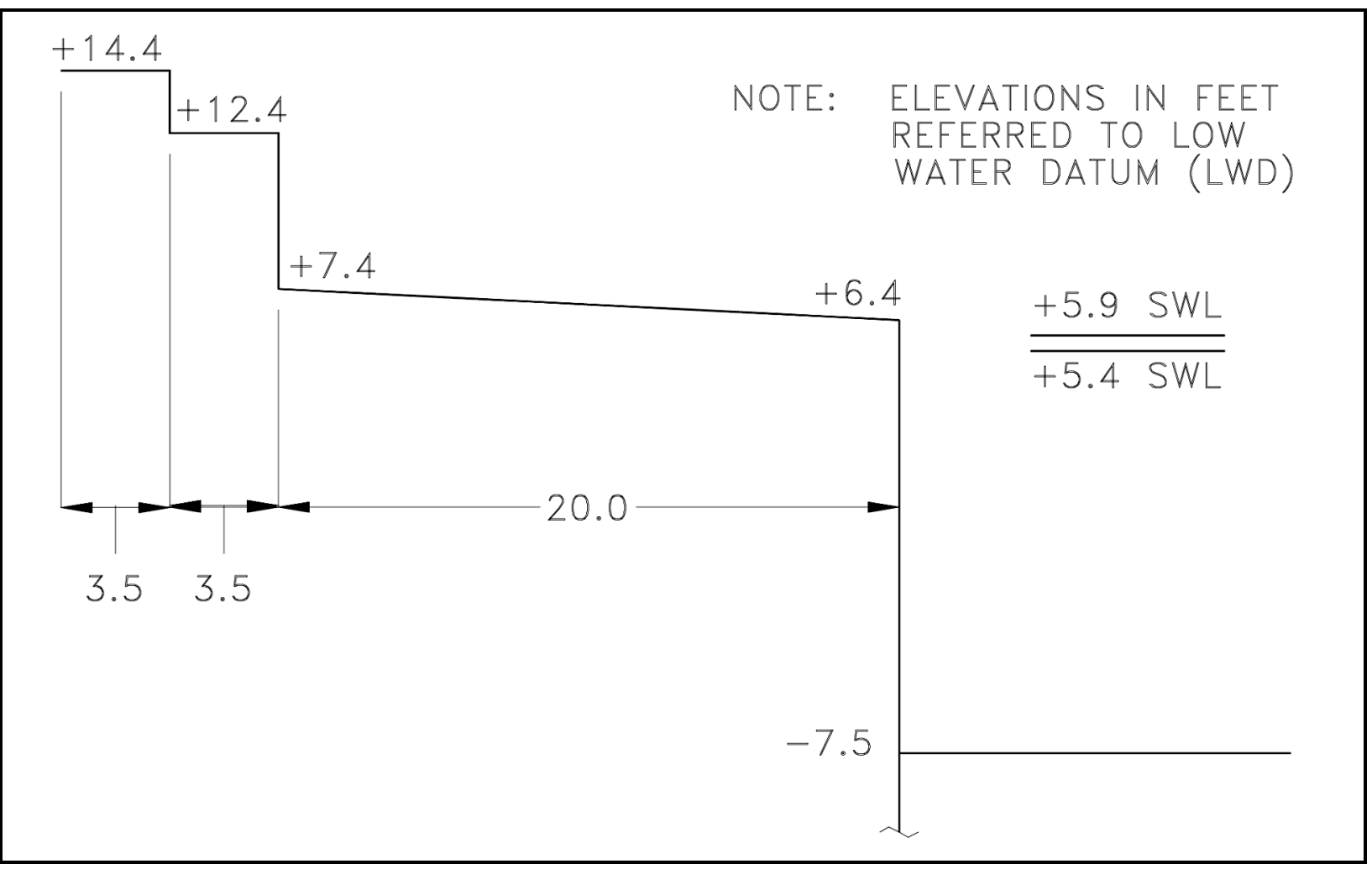

Figure 8. Cross-section of "as-built" configuration as reproduced in model

As discussed earlier, a borrow trough was located offshore of some segments of the prototype revetment, and it was unknown whether the borrow trough was causing an increase or decrease in overtopping rates. Overtopping rates for the 
"as-built" structure were therefore measured both with and without the borrow trough to determine the most critical overtopping condition. As seen in Table 2, overtopping rates are significantly higher at the 10-year water level for tests without the trough. At the 20-year water level, the presence of the trough had little effect on overtopping rates. The 10-year and 20-year water levels were selected as the maximum water level expected during a design storm event. Actual water levels during the storm will be less than maximum during most of the storm due to fluctuations in storm surge. Because the overtopping tests indicated that overtopping rates were higher in the absence of the borrow trough at lower water levels, all additional tests were conducted without the borrow trough.

\begin{tabular}{|c|c|c|c|c|c|c|c|c|c|}
\hline \multicolumn{10}{|c|}{$\begin{array}{l}\text { Table } 2 \\
\text { Overtopping Rates (Prototype) for the As-Built Structure and Plans A, B, C, and D }\end{array}$} \\
\hline \multirow[b]{3}{*}{ Plan } & \multirow{3}{*}{$\begin{array}{l}\text { Promenade } \\
\text { Elevation } \\
\mathrm{m}(\mathrm{ft})\end{array}$} & \multirow{3}{*}{$\begin{array}{l}\text { Terminal } \\
\text { Elevation } \\
\text { of } \\
\text { Structure } \\
\mathrm{m}(\mathrm{ft}) \\
\end{array}$} & \multirow[b]{3}{*}{$\begin{array}{l}\text { Number } \\
\text { of Steps }\end{array}$} & \multirow{3}{*}{$\begin{array}{l}\text { Width of } \\
\text { Promenade } \\
\text { m (ft) }\end{array}$} & \multirow[b]{3}{*}{ Trough } & \multicolumn{4}{|c|}{ Overtopping Rate, $\mathrm{m}^{3} / \mathrm{s} / \mathrm{m}\left(\mathrm{ft}^{3} / \mathrm{s} / \mathrm{ft}\right)$} \\
\hline & & & & & & \multicolumn{2}{|c|}{ 10-Year Water Level } & \multicolumn{2}{|c|}{ 20-Year Water Level } \\
\hline & & & & & & $\begin{array}{l}\text { 10-Year } \\
\text { Wave }\end{array}$ & $\begin{array}{l}20 \text {-Year } \\
\text { Wave }\end{array}$ & $\begin{array}{l}\text { 10-Year } \\
\text { Wave }\end{array}$ & $\begin{array}{l}\text { 20-Year } \\
\text { Wave }\end{array}$ \\
\hline \multirow[t]{2}{*}{$\begin{array}{l}\text { "As- } \\
\text { Built" }\end{array}$} & $\begin{array}{l}1.95 \\
(6.4) \\
\end{array}$ & $4.39(14.4)$ & 2 & $6.1(20.0)$ & w/ trough & $\begin{array}{l}0.073 \\
(0.79) \\
\end{array}$ & $\begin{array}{l}0.091 \\
(0.98) \\
\end{array}$ & $\begin{array}{l}0.123 \\
(1.33) \\
\end{array}$ & $\begin{array}{l}0.131 \\
(1.41) \\
\end{array}$ \\
\hline & $\begin{array}{l}1.95 \\
(6.4) \\
\end{array}$ & $4.39(14.4)$ & 2 & $6.1(20.0)$ & \begin{tabular}{|l|} 
w/o \\
trough
\end{tabular} & $\begin{array}{l}0.112 \\
(1.21) \\
\end{array}$ & $\begin{array}{l}0.112 \\
(1.20) \\
\end{array}$ & $\begin{array}{l}0.117 \\
(1.27) \\
\end{array}$ & $\begin{array}{l}0.134 \\
(1.44) \\
\end{array}$ \\
\hline Plan A & $\begin{array}{l}1.83 \\
(6.0) \\
\end{array}$ & $3.81(12.5)$ & 2 & $9.1(30.0)$ & \begin{tabular}{|l|} 
w/o \\
trough
\end{tabular} & $\begin{array}{l}0.131 \\
(1.41) \\
\end{array}$ & $\begin{array}{l}0.134 \\
(1.45) \\
\end{array}$ & $\begin{array}{l}0.149 \\
(1.61) \\
\end{array}$ & \begin{tabular}{|l}
0.157 \\
$(1.69)$ \\
\end{tabular} \\
\hline Plan B & $\begin{array}{l}1.83 \\
(6.0) \\
\end{array}$ & $5.49(18.0)$ & 4 & $9.1(30.0)$ & \begin{tabular}{|l|} 
w/o \\
trough
\end{tabular} & $\begin{array}{l}0.019 \\
(0.20) \\
\end{array}$ & $\begin{array}{l}0.022 \\
(0.23) \\
\end{array}$ & $\begin{array}{l}0.028 \\
(0.31) \\
\end{array}$ & \begin{tabular}{|l}
0.029 \\
$(0.31)$ \\
\end{tabular} \\
\hline Plan C & $\begin{array}{l}1.83 \\
(6.0) \\
\end{array}$ & $5.49(18.0)$ & 4 & $6.1(20.0)$ & \begin{tabular}{|l|} 
w/o \\
trough
\end{tabular} & $\begin{array}{l}0.027 \\
(0.29) \\
\end{array}$ & $\begin{array}{l}0.029 \\
(0.31) \\
\end{array}$ & $\begin{array}{l}0.041 \\
(0.44) \\
\end{array}$ & $\begin{array}{l}0.041 \\
(0.45) \\
\end{array}$ \\
\hline Plan D & $\begin{array}{l}1.22 \\
(4.0) \\
\end{array}$ & $5.49(18.0)$ & 4 & $9.1(30.0)$ & $\begin{array}{l}\text { w/o } \\
\text { trough }\end{array}$ & $\begin{array}{l}0.026 \\
(0.28) \\
\end{array}$ & $\begin{array}{l}0.027 \\
(0.29) \\
\end{array}$ & $\begin{array}{l}0.035 \\
(0.37) \\
\end{array}$ & $\begin{array}{l}0.037 \\
(0.40) \\
\end{array}$ \\
\hline
\end{tabular}

The 10 -year storm generated at the 20 -year water level was selected by LRC as the design storm. Overtopping rates were measured for all remaining revetment configurations in Phase I at the design storm. Overtopping rates for Plans A, B, C, and D were also measured at other combinations of the 10- and 20-year storm and 10- and 20-year water level.

Plan A. Plan A included a vertical seawall to a promenade at a height of $+1.83 \mathrm{~m}(+6.0 \mathrm{ft})$, a $9.14-\mathrm{m}(30.0-\mathrm{ft})$ wide promenade sloping to an elevation of $+1.98 \mathrm{~m}(+6.5 \mathrm{ft})$, a $0.91-\mathrm{m}$ high by $2.44-\mathrm{m}$ wide $(3.0 \mathrm{ft}$ by $8.0 \mathrm{ft})$ step, and a $0.91-\mathrm{m}$ high by $1.52-\mathrm{m}$ wide step $(3.0 \mathrm{ft}$ by $5.0 \mathrm{ft}$ ), for an elevation at the shoreward side of $+3.81 \mathrm{~m}(+12.5 \mathrm{ft})^{1}$ (Figure 9). Comparing Plan A to the "asbuilt" configuration, it is seen that Plan A has a wider promenade and lower crest elevation than the original design. Overtopping rate for the 10 -year storm at the 20 -year water level was measured as $0.149 \mathrm{~m}^{3} / \mathrm{s}$ for each meter of length along the revetment crest $\left(1.61 \mathrm{ft}^{3} / \mathrm{s} / \mathrm{ft}\right)$; other overtopping rates are listed in Table 2 .

\footnotetext{
${ }^{1}$ Revetment cross-sections were constructed in non-SI units and converted to SI units for this report. Sums of SI measurements, such as the sum of individual step heights, may differ from the values given in this report due to round-off errors.
} 


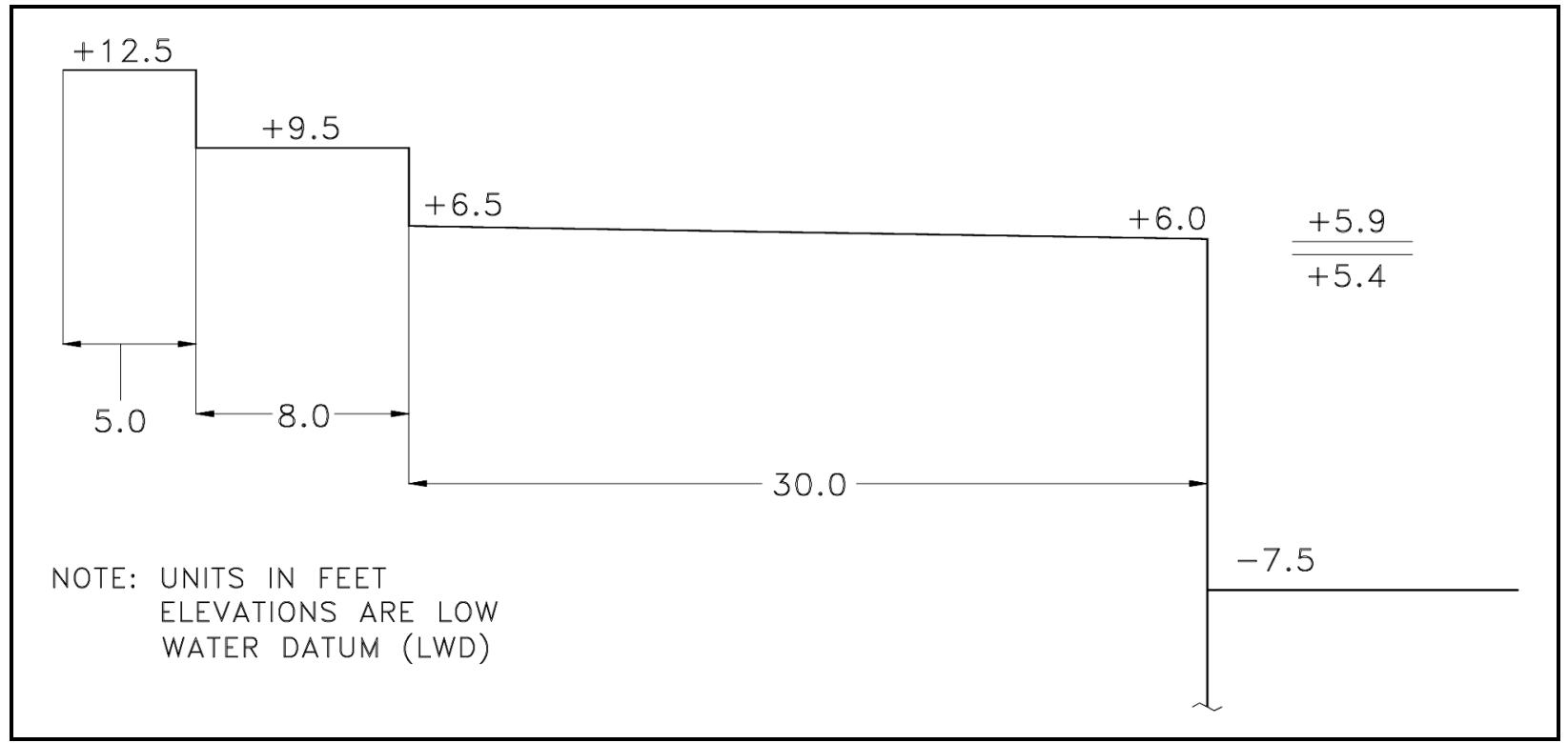

Figure 9. Cross-section of Plan A

Overtopping of the "as-built" configuration was considered unacceptably high; overtopping on Plan A was even greater.

The measured overtopping rate for Plan A was unacceptably high. Several changes were made to Plan A and tested with the 20-year water level and 10-year wave conditions. For the sake of expediency, these modifications were conducted with tests of short duration (roughly $10 \mathrm{~min}$ ) that could not guarantee accurate reproduction of the design spectrum. Accuracy of the overtopping measurements was therefore limited, but provided an indication of the relative effectiveness of a variety of design options. The modifications are described below.

Plan A1: An additional step was added to the landward side of Plan A. The extra step was $0.67-\mathrm{m}$ high $(2.2-\mathrm{ft})$ and $2.44-\mathrm{m}$ wide $(8.0-\mathrm{ft})$, raising the top elevation of the revetment to $+4.48 \mathrm{~m}(+14.7 \mathrm{ft})$. The additional step reduced the overtopping rate from $0.149 \mathrm{~m}^{3} / \mathrm{s} / \mathrm{m}\left(1.61 \mathrm{ft}^{3} / \mathrm{s} / \mathrm{ft}\right)$ for Plan A to $0.095 \mathrm{~m}^{3} / \mathrm{s} / \mathrm{m}\left(1.02 \mathrm{ft}^{3} / \mathrm{s} / \mathrm{ft}\right)$ for Plan A1. Plan A1 is illustrated in Figure 10.

Plan A2: The extra step used in Plan A1 was removed and a parapet was placed on the promenade. The parapet measured $0.91-\mathrm{m}$ by $0.91-\mathrm{m}(3.0-\mathrm{ft}$ by $3.0-\mathrm{ft})$ and was placed approximately $3.6 \mathrm{~m}(12.0 \mathrm{ft})$ shoreward of the lakeward edge of the revetment. The area shoreward of the parapet quickly filled with water which minimized the effectiveness of the parapet. Overtopping rate for Plan A2 was $0.121 \mathrm{~m}^{3} / \mathrm{s} / \mathrm{m}\left(1.30 \mathrm{ft}^{3} / \mathrm{s} / \mathrm{ft}\right)$, or roughly the same as the as-built configuration. Plan A2 is illustrated in Figure 11. 


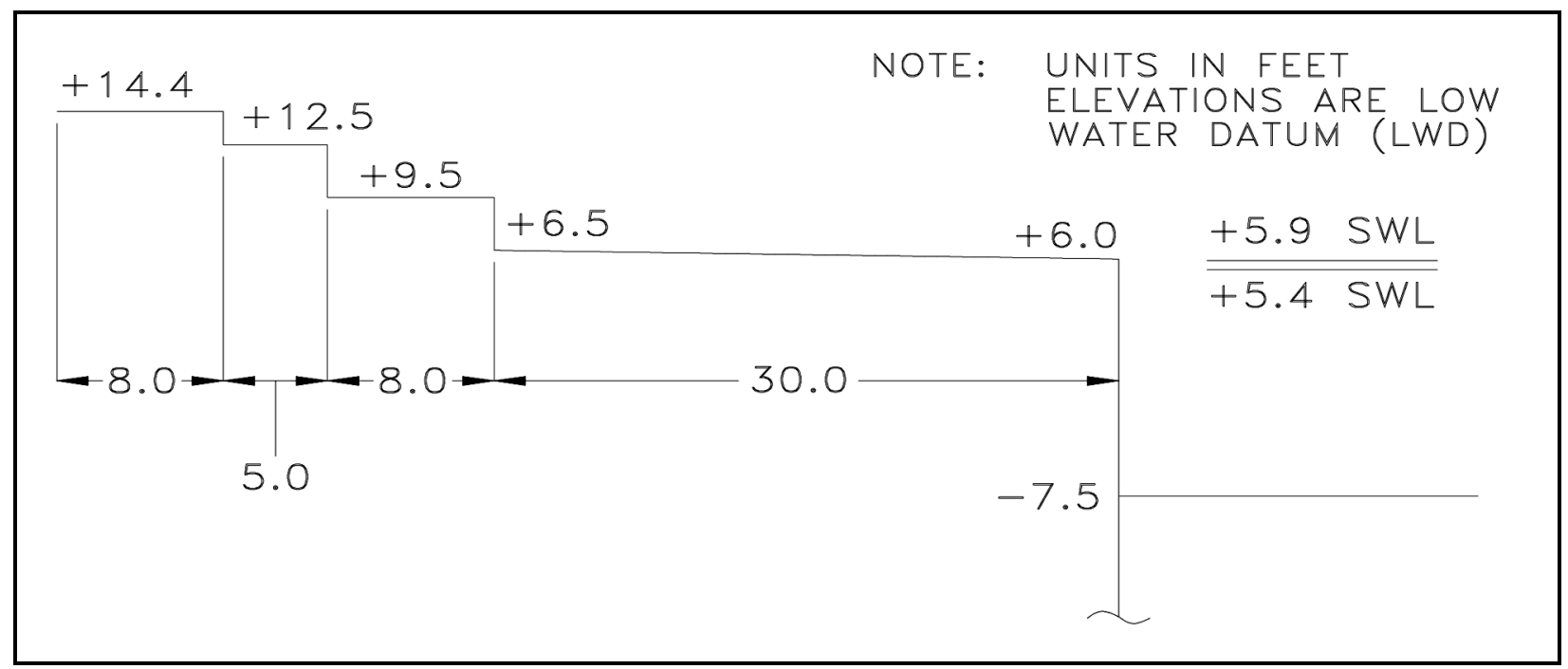

Figure 10. Cross-section of Plan A1

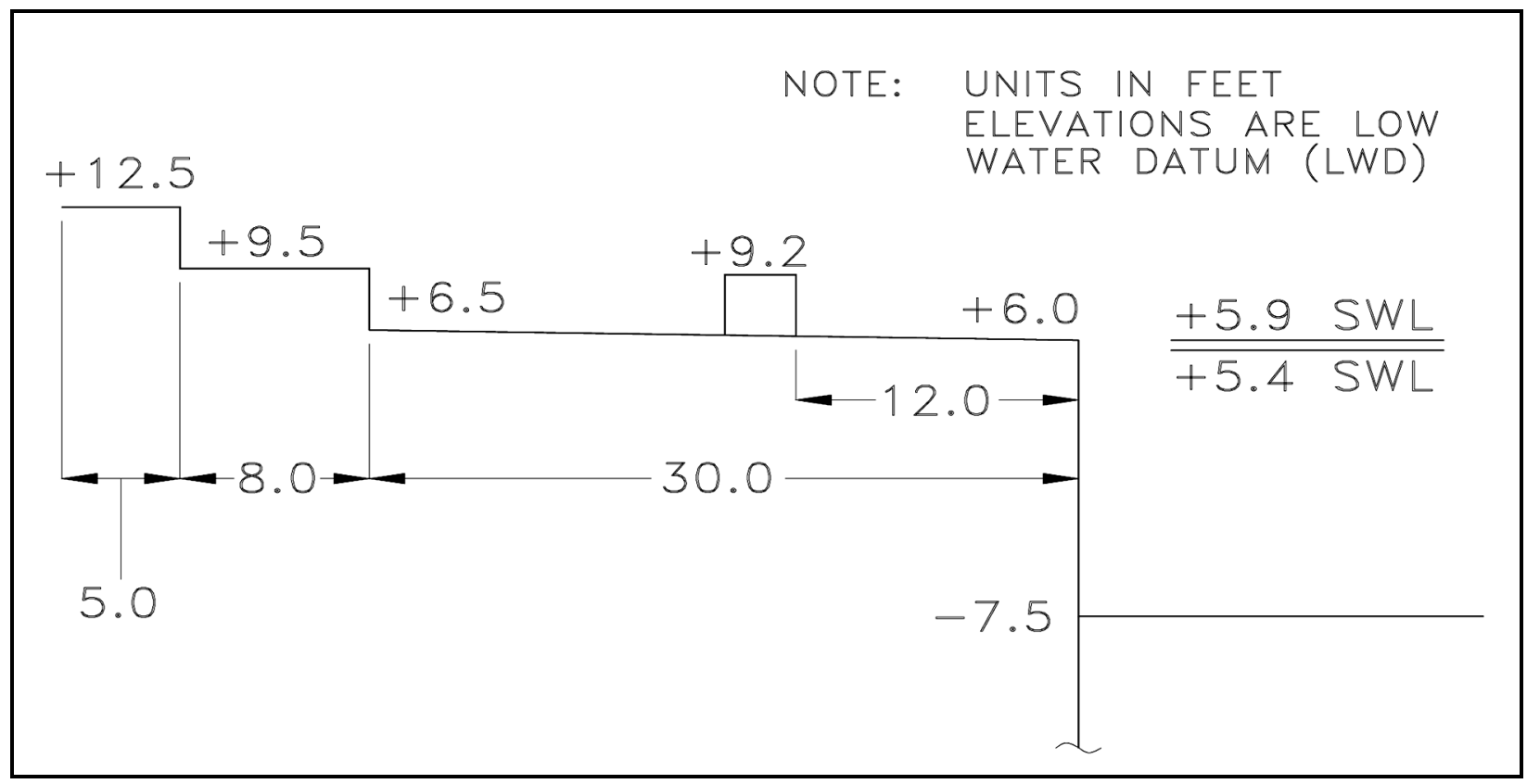

Figure 11. Cross-section of Plan A2

Plan A3: The parapet from Plan A2 was left in place, and an offshore reef was constructed of 2.7- to 8.2-tonne stone (3- to 9-ton). The offshore reef was approximately $2.44-\mathrm{m}$ high $(8.0 \mathrm{ft})$ by $15.20-\mathrm{m}$ wide $(50.0-\mathrm{ft})$ with the nearshore toe of the reef located $30.5 \mathrm{~m}(100 \mathrm{ft})$ lakeward of the revetment. The offshore reef reduced the overtopping rate to $0.094 \mathrm{~m}^{3} / \mathrm{s} / \mathrm{m}$ $\left(1.01 \mathrm{ft}^{3} / \mathrm{s} / \mathrm{ft}\right)$. Plan A3 is illustrated in Figure 12.

Plan A4: The parapet from Plan A2 was removed, leaving the offshore reef from Plan A3. Overtopping rate was $0.096 \mathrm{~m}^{3} / \mathrm{s} / \mathrm{m}\left(1.03 \mathrm{ft}^{3} / \mathrm{s} / \mathrm{ft}\right)$, or nearly the same as with the parapet in place (Plan A3). Plan A4 is illustrated in Figure 13. 


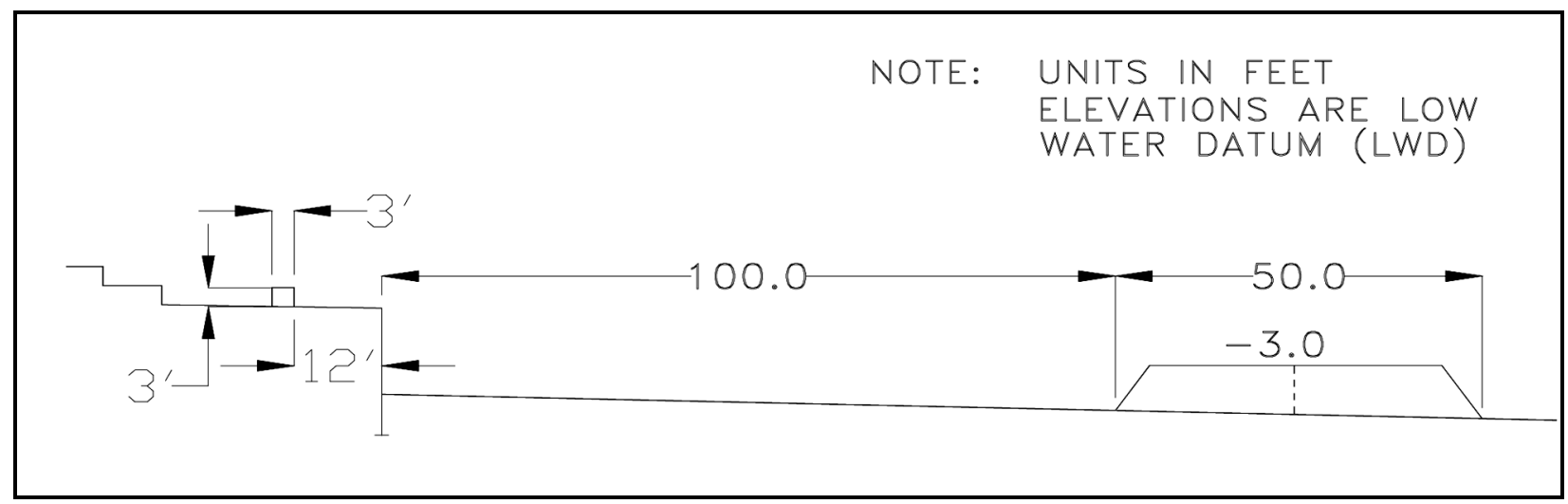

Figure 12. Cross-section of Plan A3 with offshore reef

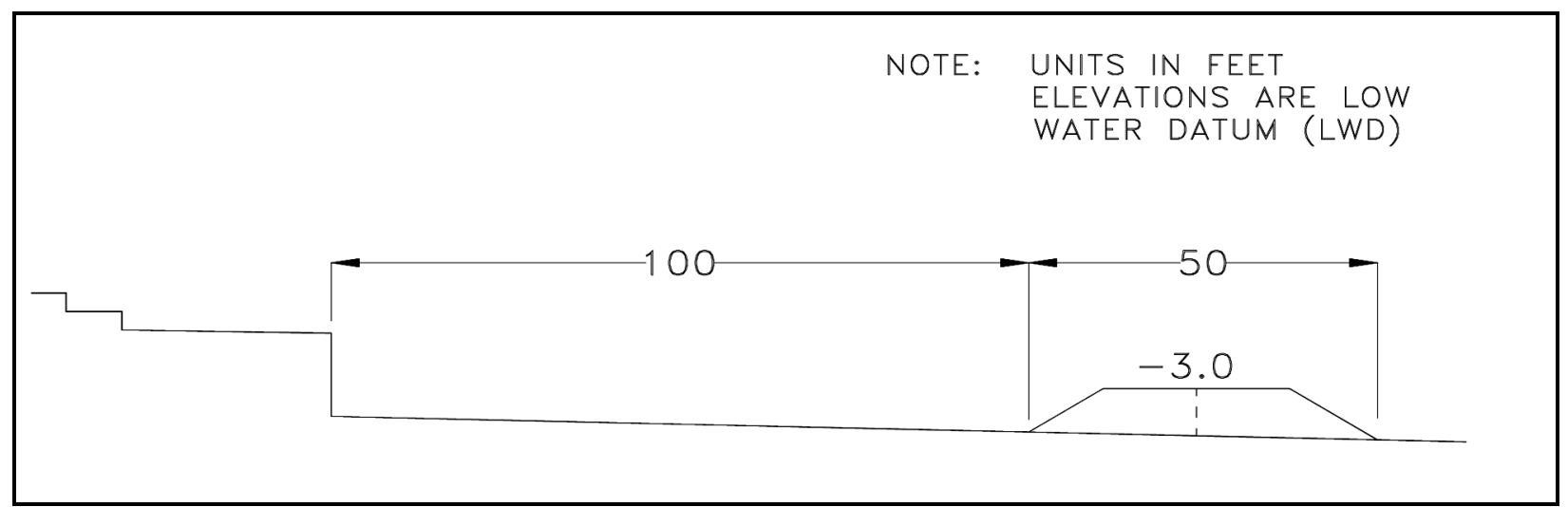

Figure 13. Cross-section of Plan A4 with offshore reef and no parapet

Plan A5: The offshore reef from Plan A3 was again left in place, and a new parapet was placed on the promenade. This parapet was $1.52-\mathrm{m}$ high $(5.0 \mathrm{ft})$ and constructed in segments to allow water to drain lakeward from behind the parapet. Each segment was $5.33-\mathrm{m}$ long $(17.5 \mathrm{ft})$ and placed with gaps of $2.67 \mathrm{~m}(8.8 \mathrm{ft})$ between segments. Overtopping rate was reduced 50 percent from Plan A to $0.046 \mathrm{~m}^{3} / \mathrm{s} / \mathrm{m}\left(0.50 \mathrm{ft}^{3} / \mathrm{s} / \mathrm{ft}\right)$. The high, segmented parapet in Plan A5 proved to be very effective at reducing overtopping rates while maintaining the low crest elevation of Plan A. Plan A5 is illustrated in Figure 14.

Overtopping rates for each of the modifications to Plan A are shown in Table 3.

Plan B. Plan B included the same revetment used in Plan A, but added two additional steps landward of the steps in Plan A. The first step was 0.91-m high $(3.0 \mathrm{ft})$ by $2.44-\mathrm{m}$ wide $(8.0 \mathrm{ft})$. The second step was $0.76-\mathrm{m}$ high $(2.5 \mathrm{ft})$ by $1.52-\mathrm{m}$ wide $(5.0 \mathrm{ft})$, bringing the top of the revetment to an elevation of $+5.49 \mathrm{~m}$ $(+18.0 \mathrm{ft})$. By continuing the revetment steps up an additional $1.67 \mathrm{~m}(5.5 \mathrm{ft})$ over Plan A, the overtopping rate relative to Plan A was reduced by more than 80 percent to $0.028 \mathrm{~m}^{3} / \mathrm{s} / \mathrm{m}\left(0.31 \mathrm{ft}^{3} / \mathrm{s} / \mathrm{ft}\right)$. Plan B is illustrated in Figure 15 . 


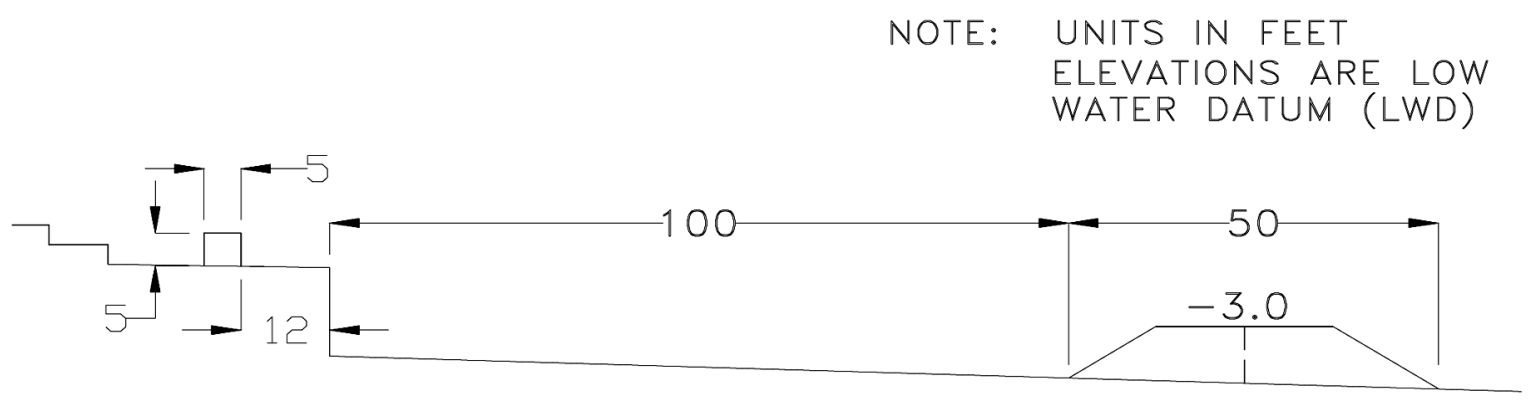

Figure 14. Cross-section of Plan A5 with large parapet and offshore reef

\begin{tabular}{|c|c|c|c|c|c|c|}
\hline $\begin{array}{l}\text { Plan } \\
\text { Modification }\end{array}$ & $\begin{array}{l}\text { Promenade } \\
\text { Elevation } \\
\mathrm{m}(\mathrm{ft})\end{array}$ & $\begin{array}{l}\text { Terminal } \\
\text { Elevation of } \\
\text { Structure } \\
m \text { (ft) }\end{array}$ & $\begin{array}{l}\text { Number of } \\
\text { Steps }\end{array}$ & $\begin{array}{l}\text { Width of } \\
\text { Promenade } \\
\mathrm{m}(\mathrm{ft})\end{array}$ & Other Features & $\begin{array}{l}\text { Overtopping } \\
\text { Rate } \\
\mathrm{m}^{3} / \mathrm{s} / \mathrm{m}\left(\mathrm{ft}^{3} / \mathrm{s} / \mathrm{ft}\right)\end{array}$ \\
\hline A1 & $1.95(6.4)$ & $4.48(14.7)$ & 3 & $9.14(30.0)$ & Extra Step & $0.095(1.02)$ \\
\hline $\mathrm{A} 2$ & $1.95(6.4)$ & $3.81(12.5)$ & 2 & $9.14(30.0)$ & small parapet & $0.121(1.30)$ \\
\hline A3 & $1.95(6.4)$ & $3.81(12.5)$ & 2 & $9.1 .4(30.0)$ & $\begin{array}{l}\text { small parapet } \\
\text { plus offshore } \\
\text { reef }\end{array}$ & $0.094(1.01)$ \\
\hline A4 & $1.95(6.4)$ & $3.81(12.5)$ & 2 & $9.14(30.0)$ & offshore reef & $0.096(1.03)$ \\
\hline A5 & $1.95(6.4)$ & $3.81(12.5)$ & 2 & $9.14(30.0)$ & $\begin{array}{l}\text { large segmented } \\
\text { parapet plus } \\
\text { offshore reef }\end{array}$ & $0.046(0.50)$ \\
\hline C1 & $1.83(6.0)$ & $5.49(18.0)$ & 4 & $6.10(20.0)$ & $\begin{array}{l}\text { promenade on } \\
\text { first step }\end{array}$ & $0.032(0.34)$ \\
\hline D1 & $1.22(4.0)$ & $5.03(16.5)$ & 4 & $9.14(30.0)$ & $\begin{array}{l}\text { lower elev plus } \\
\text { offshore reef }\end{array}$ & $0.023(0.25)$ \\
\hline D2 & $1.22(4.0)$ & $5.03(16.5)$ & 4 & $9.14(30.0)$ & lower elev & $0.040(0.43)$ \\
\hline D3 & $1.22(4.0)$ & $5.03(16.5)$ & 4 & $9.14(30.0)$ & $\begin{array}{l}\text { lower elev plus } \\
\text { overhang }\end{array}$ & $0.041(0.44)$ \\
\hline
\end{tabular}

Plan C. Plan C used the same step configuration as Plan B, but narrowed the promenade to a width of $6.10 \mathrm{~m}(20 \mathrm{ft})$. As in Plan $\mathrm{B}$, the promenade sloped from an elevation of $+1.83 \mathrm{~m}(+6.0 \mathrm{ft})$ at the lakeward edge to $+1.98 \mathrm{~m}(+6.5 \mathrm{ft})$ at the base of the steps. All steps were the same height, width, and elevation as in Plan B. Reducing the promenade width increased the overtopping rate to $0.041 \mathrm{~m}^{3} / \mathrm{s} / \mathrm{m}\left(0.44 \mathrm{ft}^{3} / \mathrm{s} / \mathrm{ft}\right)$ compared to $0.028 \mathrm{~m}^{3} / \mathrm{s} / \mathrm{m}\left(0.31 \mathrm{ft}^{3} / \mathrm{s} / \mathrm{ft}\right)$ in Plan B. Plan C is illustrated in Figure 16.

Plan C1: A variation of Plan C was tested by moving the promenade from the lowest level (at the top of the seawall) to the elevation of the first step. Top of the seawall was at $+1.83 \mathrm{~m}(+6.0 \mathrm{ft})$. The first step extended back 


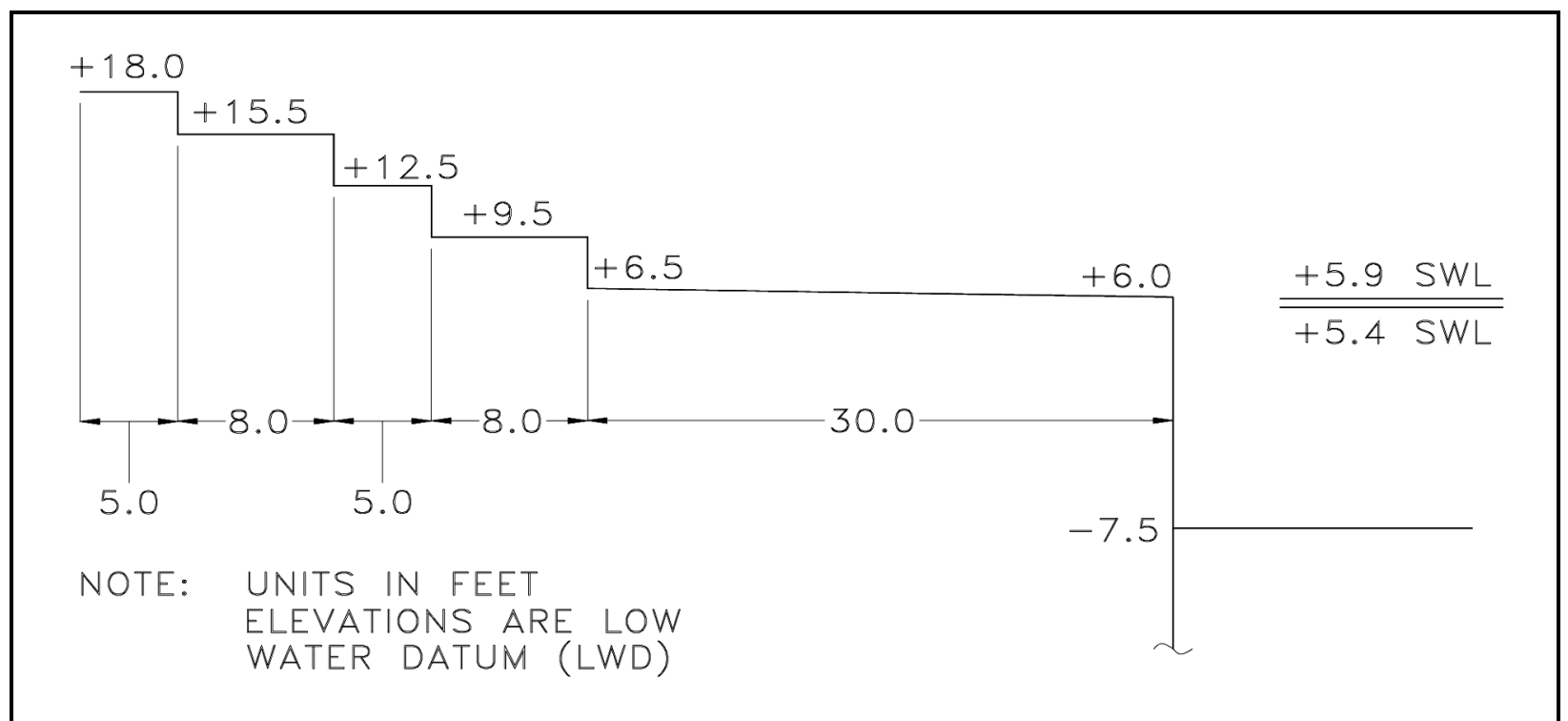

Figure 15. Cross-section of Plan B

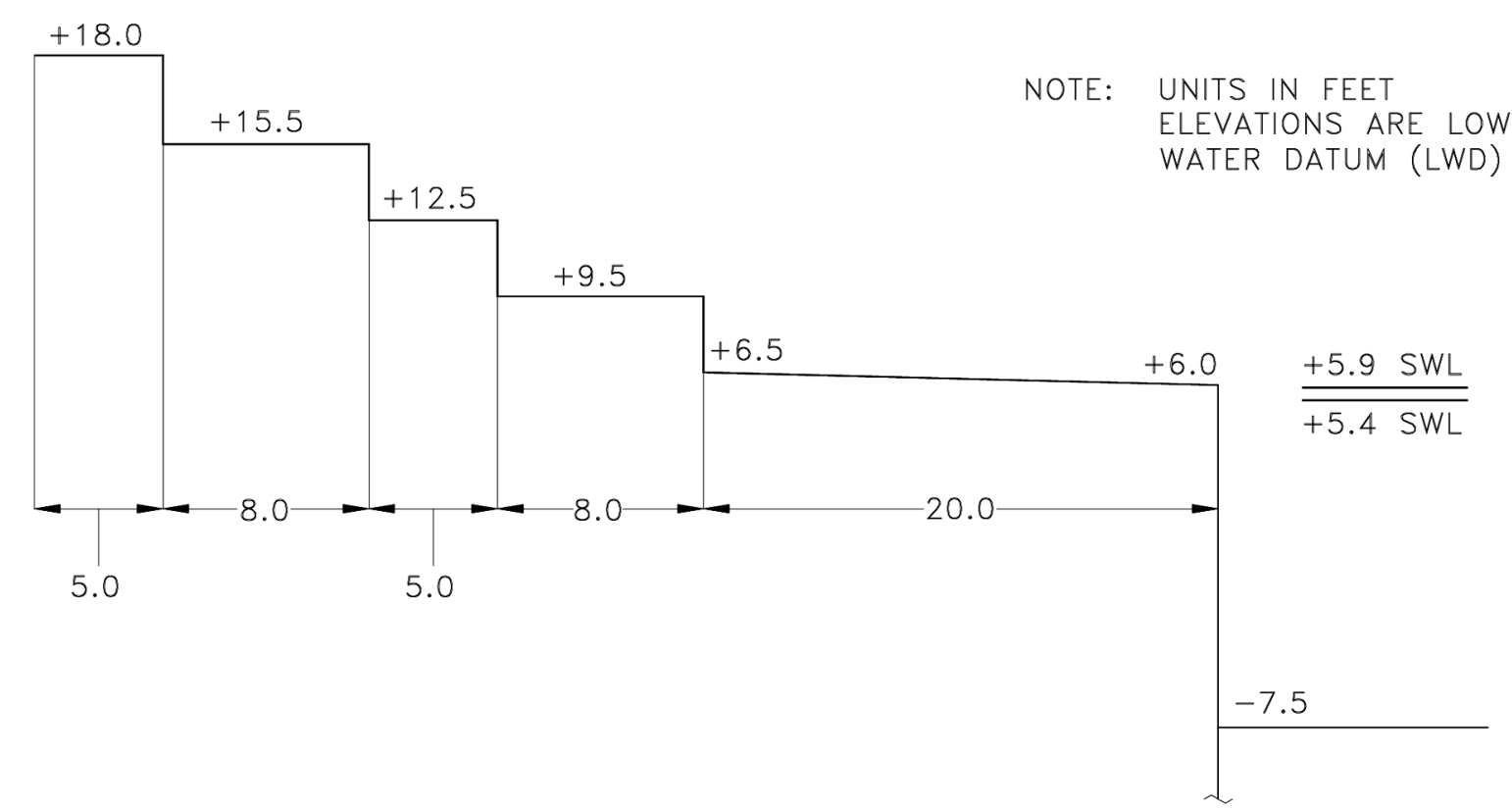

Figure 16. Cross-section of Plan C

from the seawall a distance of $2.44 \mathrm{~m}(8.0 \mathrm{ft})$, then stepped up $0.91 \mathrm{~m}(3.0$ $\mathrm{ft})$. The promenade extended from the top of the first step back a distance of $6.10 \mathrm{~m}(20 \mathrm{ft})$. Shoreward of the promenade the steps were similar to Plan C, with the crest of the revetment at an elevation of $+5.49 \mathrm{~m}(+18.0$ $\mathrm{ft})$. Overtopping rate was reduced to $0.032 \mathrm{~m}^{3} / \mathrm{s} / \mathrm{m}\left(0.34 \mathrm{ft}^{3} / \mathrm{s} / \mathrm{ft}\right)$ from $0.041 \mathrm{~m}^{3} / \mathrm{s} / \mathrm{m}\left(0.44 \mathrm{ft}^{3} / \mathrm{s} / \mathrm{ft}\right)$ in Plan C. Plan C1 is illustrated if Figure 17. 


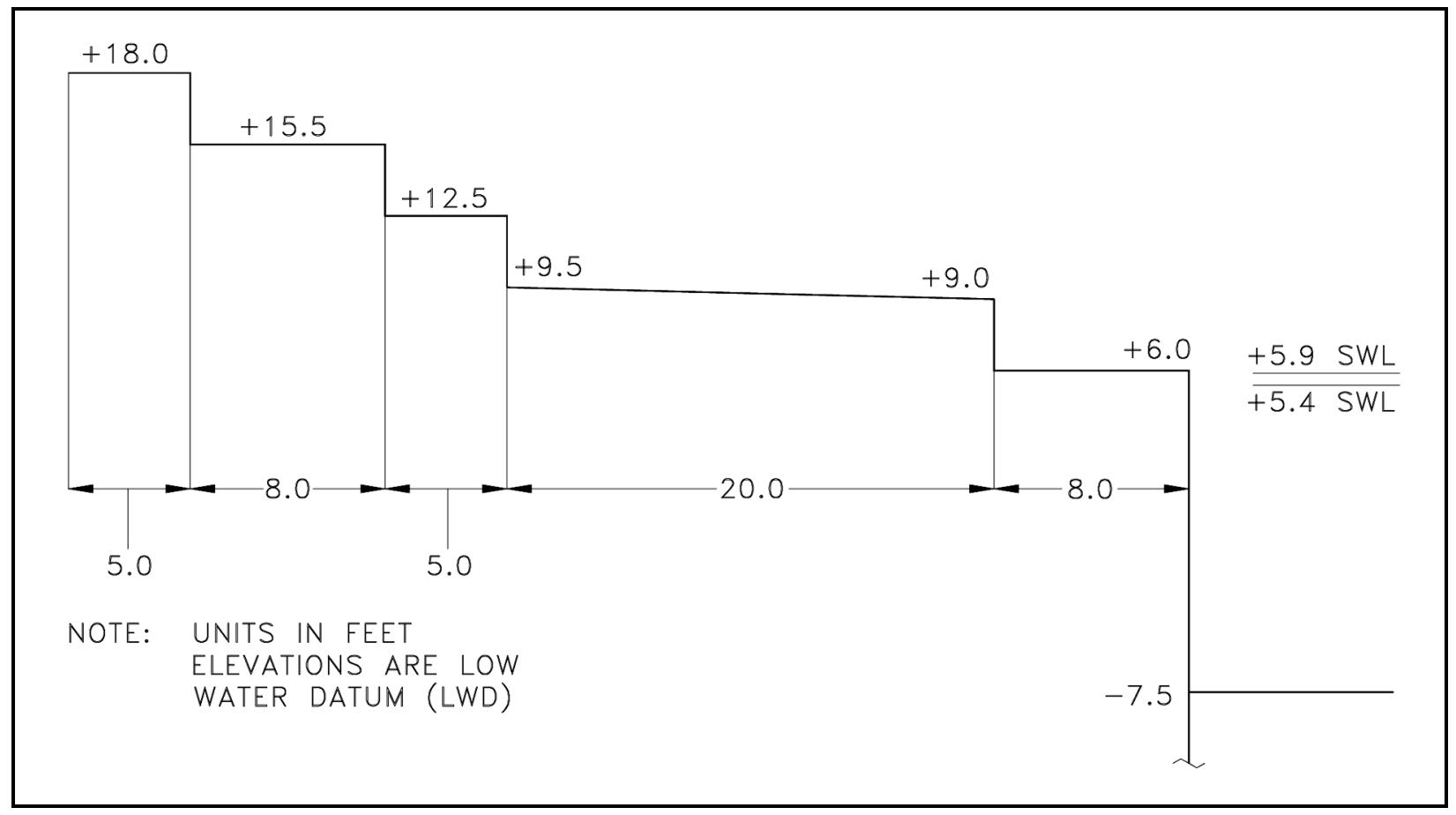

Figure 17. Cross-section of Plan C1

Plan D. Plan D extended the promenade back to the $9.14-\mathrm{m}$ width $(30.0 \mathrm{ft})$ used in Plans A and B, but lowered the elevation of the seaward edge of the promenade to $+1.22 \mathrm{~m}(+4.0 \mathrm{ft})$. The promenade sloped to an elevation of +1.52 $\mathrm{m}(+5.0 \mathrm{ft})$ at the base of the steps. The first step was $2.44-\mathrm{m}$ wide $(8.0 \mathrm{ft})$ at an elevation of $+2.44 \mathrm{~m}(+8.0 \mathrm{ft})$, second step was $1.52-\mathrm{m}$ wide $(5.0 \mathrm{ft})$ at an elevation of $+3.35 \mathrm{~m}(+11.0 \mathrm{ft})$, third step was $2.44-\mathrm{m}$ wide $(8.0 \mathrm{ft})$ at an elevation of $+4.27 \mathrm{~m}(+14.0 \mathrm{ft})$, and the fourth step was $1.52-\mathrm{m}$ wide $(5.0 \mathrm{ft})$ at an elevation of $+5.49 \mathrm{~m}(+18.0 \mathrm{ft})$. Plan $\mathrm{D}$ had the same overall width and crown elevation as Plan B, but the promenade was lower in Plan D and the steps were higher. Overtopping rate in Plan D was $0.035 \mathrm{~m}^{3} / \mathrm{s} / \mathrm{m}\left(0.37 \mathrm{ft}^{3} / \mathrm{s} / \mathrm{ft}\right)$, or about 25 percent higher than Plan B. Plan D is illustrated in Figure 18.

The crest elevation of Plan D was lowered from $+5.49 \mathrm{~m}(+18.0 \mathrm{ft})$ to +5.03 $\mathrm{m}(+16.5 \mathrm{ft})$ for a series of short-duration tests with modified versions of Plan D. The lower crest elevation was obtained by reducing the height of the fourth step, all other dimensions of the revetment remained the same. Test configurations with the modified Plan D are described below.

Plan D1: In addition to the lowered crest elevation, Plan D1 included the offshore reef described in Plan A3. The reef was $2.44-\mathrm{m}$ high $(8.0-\mathrm{ft})$ by $15.2-\mathrm{m}$ wide $(50.0 \mathrm{ft})$ and located $30.5 \mathrm{~m}(100 \mathrm{ft})$ lakeward of the seawall. The measured overtopping rate of $0.023 \mathrm{~m}^{3} / \mathrm{s} / \mathrm{m}\left(0.25 \mathrm{ft}^{3} / \mathrm{s} / \mathrm{ft}\right)$ was a reduction of more than 40 percent over the same configuration without the offshore reef (Plan D2). Plan D1 is illustrated in Figure 19. 


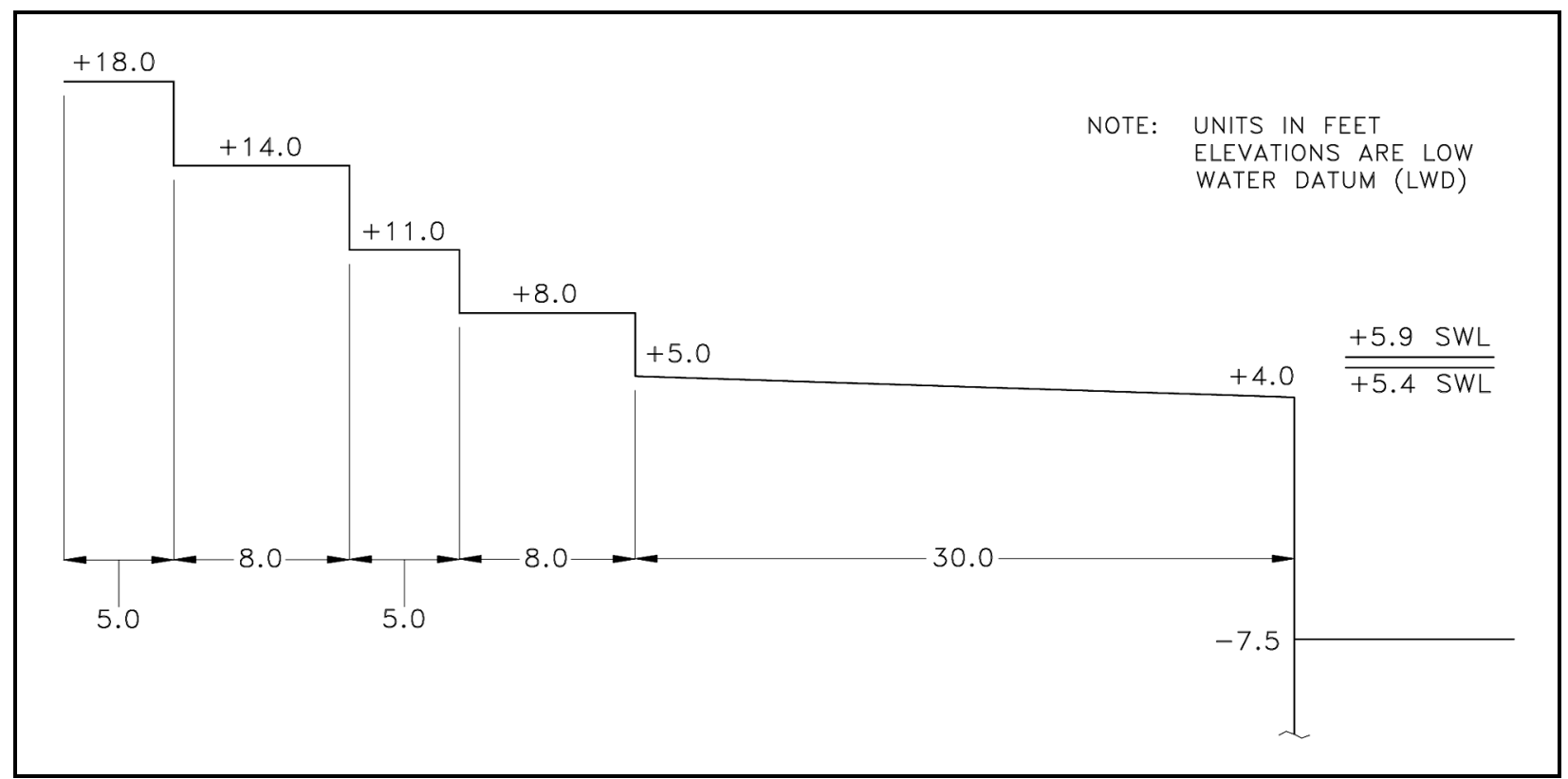

Figure 18. Cross-section of Plan D
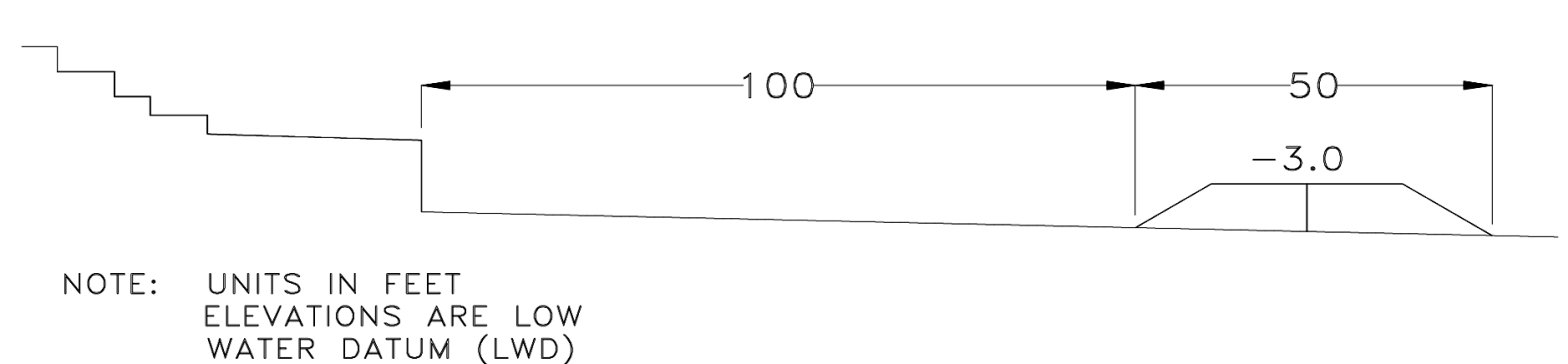

Figure 19. Cross-section of Plan D1 with offshore reef

Plan D2: Plan D2 removed the offshore reef and was the same as Plan D except for the lowered crest elevation. The $0.46 \mathrm{~m}(1.5 \mathrm{ft})$ lower crest elevation of Plan D2relative to Plan D allowed an overtopping rate of $0.040 \mathrm{~m}^{3} / \mathrm{s} / \mathrm{m}\left(0.43 \mathrm{ft}^{3} / \mathrm{s} / \mathrm{ft}\right)$ compared to the overtopping rate of 0.035 $\mathrm{m}^{3} / \mathrm{s} / \mathrm{m}$ for Plan D. Plan D2 is illustrated in Figure 20 .

Plan D3: Plan D3 modified the top step of Plan D2 such that the top step included an overhang over the third step. The overhang was $0.73-\mathrm{m}$ wide $(2.4 \mathrm{ft})$ and $0.11-\mathrm{m}$ thick $(0.36 \mathrm{ft})$. Surprisingly, the overtopping rate with the overhang (Plan D3) was slightly higher at $0.041 \mathrm{~m}^{3} / \mathrm{s} / \mathrm{m}\left(0.44 \mathrm{ft}^{3} / \mathrm{s} / \mathrm{ft}\right)$ than the measured overtopping rate without the overhang (Plan D2) at $0.040 \mathrm{~m}^{3} / \mathrm{s} / \mathrm{m}\left(0.43 \mathrm{ft}^{3} / \mathrm{s} / \mathrm{ft}\right)$. Plan D3 is illustrated in Figure 21 .

\section{Second set of design options}

A meeting was held at ERDC in July, 1997, with representatives from LRC, City of Chicago, and the Chicago Park District. The local sponsors of the project 


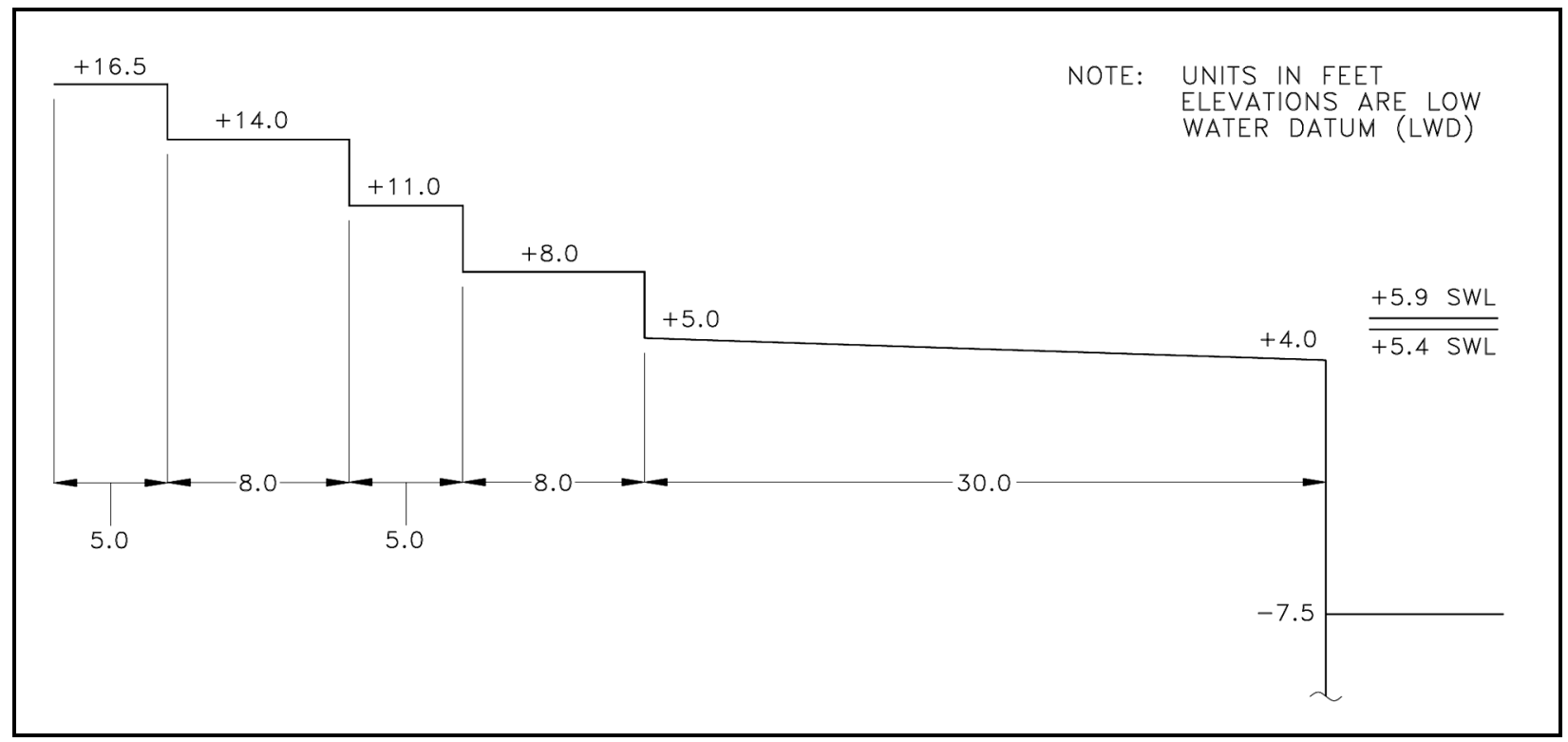

Figure 20. Cross-section of Plan D2

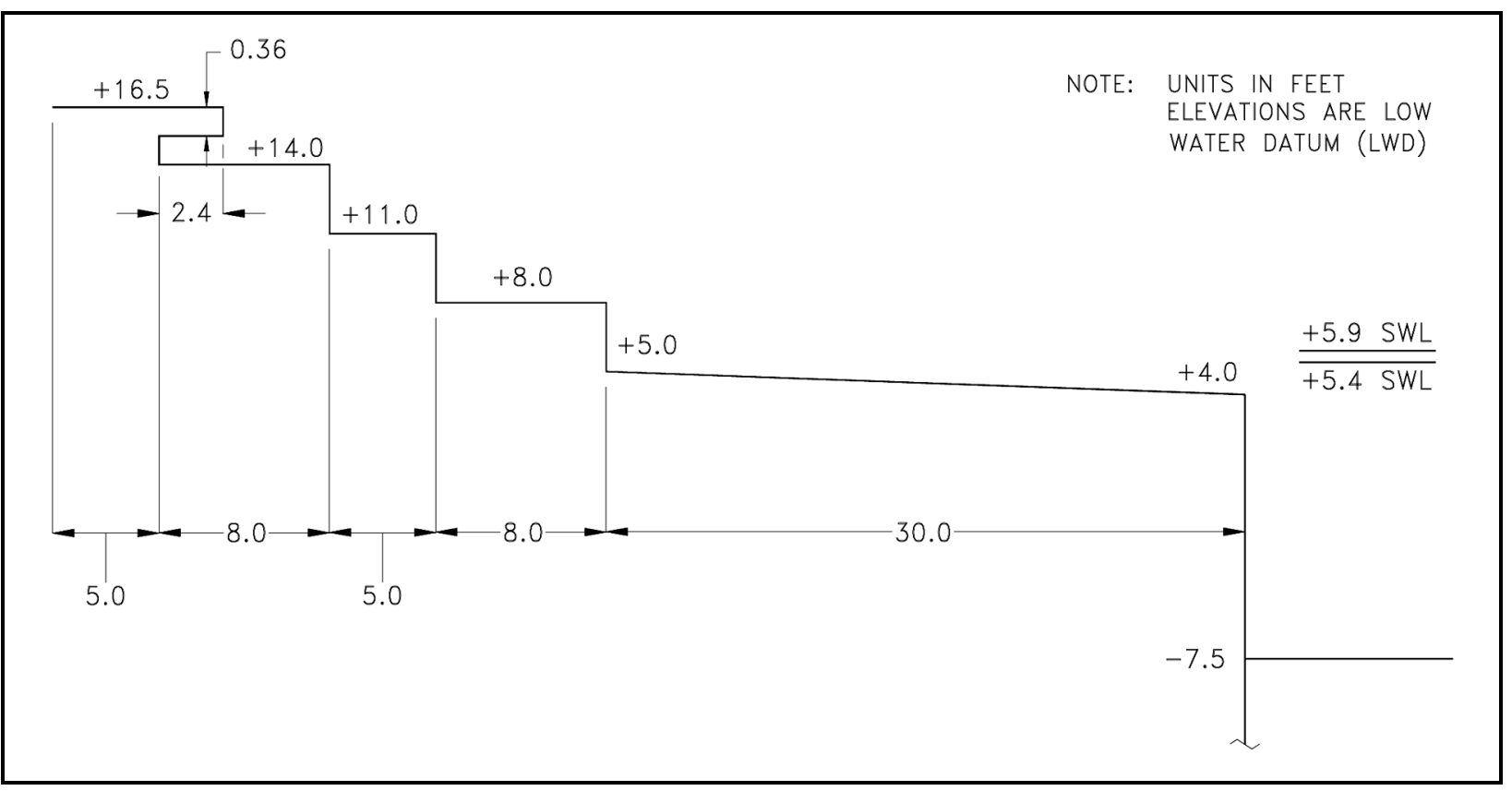

Figure 21. Cross-section of Plan D3 with overhang on top step

(City of Chicago and Chicago Park District) expressed concern over the use of an offshore reef due to potential boating hazards, and the use of a parapet on the promenade as potentially a place where muggers could hide. Also, elevations at the top of the seawall should be kept as low as possible because people would be diving off the seawall onto the toe stone. The maximum crest elevation of +5.49 $\mathrm{m}(+18 \mathrm{ft})$ used in some of the options tested was considered too high and would block the lake view from lakeside drive. Local sponsors also requested all step heights be kept as low as feasible to prevent injury to people falling off the steps. 
Within the confines of these limitations, LRC developed Plans E, F, G, and H. Crest elevations for this set of options ranged from $+4.27 \mathrm{~m}(+14.0 \mathrm{ft})$ to $+5.03 \mathrm{~m}$ $(+16.5 \mathrm{ft})$, seawall elevations included both $+1.22 \mathrm{~m}(+4.0 \mathrm{ft})$ and $+1.83 \mathrm{~m}(+6.0$ $\mathrm{ft})$, and promenade width was held constant at $9.14 \mathrm{~m}(30.0 \mathrm{ft})$. Overtopping rate for each of the different plans was determined only for the design storm (10-year storm generated at 20-year water level), and are given in Table 4.

\begin{tabular}{|c|c|c|c|c|c|}
\hline \multicolumn{6}{|c|}{$\begin{array}{l}\text { Table } 4 \\
\text { Overtopping Rates (Prototype) for Plans E, F, G, and H }\end{array}$} \\
\hline Plan & $\begin{array}{l}\text { Promenade } \\
\text { Elev. } \\
\text { m (ft) }\end{array}$ & $\begin{array}{l}\text { Terminal } \\
\text { Structure } \\
\text { Elev. } \\
\text { m (ft) }\end{array}$ & $\begin{array}{l}\text { Number of } \\
\text { Steps }\end{array}$ & $\begin{array}{l}\text { Width of } \\
\text { Promenade } \\
\mathrm{m}(\mathrm{ft})\end{array}$ & $\begin{array}{l}\text { Overtopping } \\
\text { Rate } \\
\mathrm{m}^{3} / \mathrm{s} / \mathrm{m} \\
\left(\mathrm{ft}^{3} / \mathrm{s} / \mathrm{ft}\right)\end{array}$ \\
\hline$E$ & $1.83(6.0)$ & $4.57(15.0)$ & 3 & $9.14(30.0)$ & $0.091(0.98)$ \\
\hline$F$ & $1.22(4.0)$ & $5.03(16.5)$ & 4 & $9.14(30.0)$ & $0.049(0.53)$ \\
\hline G & $1.22(4.0)$ & $4.27(14.0)$ & 3 & $9.14(30.0)$ & $0.112(1.21)$ \\
\hline $\mathrm{H}$ & $1.83(6.0)$ & $4.57(15.0)$ & $\begin{array}{l}3 \text { (recurve on } \\
\text { top step) }\end{array}$ & $9.14(3.00)$ & $0.091(0.98)$ \\
\hline
\end{tabular}

Plan E. Plan E was similar to Plan B but without the fourth step. The promenade and first two steps of Plan E were identical to Plan B, but the third step of Plan $\mathrm{E}$ was at an elevation of $+4.57 \mathrm{~m}(+15.0 \mathrm{ft})$ rather than the elevation of $+4.72 \mathrm{~m}(+15.5 \mathrm{ft})$ used in Plan B. With a crest elevation $0.91 \mathrm{~m}(3.0 \mathrm{ft})$ lower than Plan B, the overtopping rate of Plan E was more than three times greater at $0.091 \mathrm{~m}^{3} / \mathrm{s} / \mathrm{m}\left(0.98 \mathrm{ft}^{3} / \mathrm{s} / \mathrm{ft}\right)$ than Plan B. Plan E is illustrated in Figure 22.

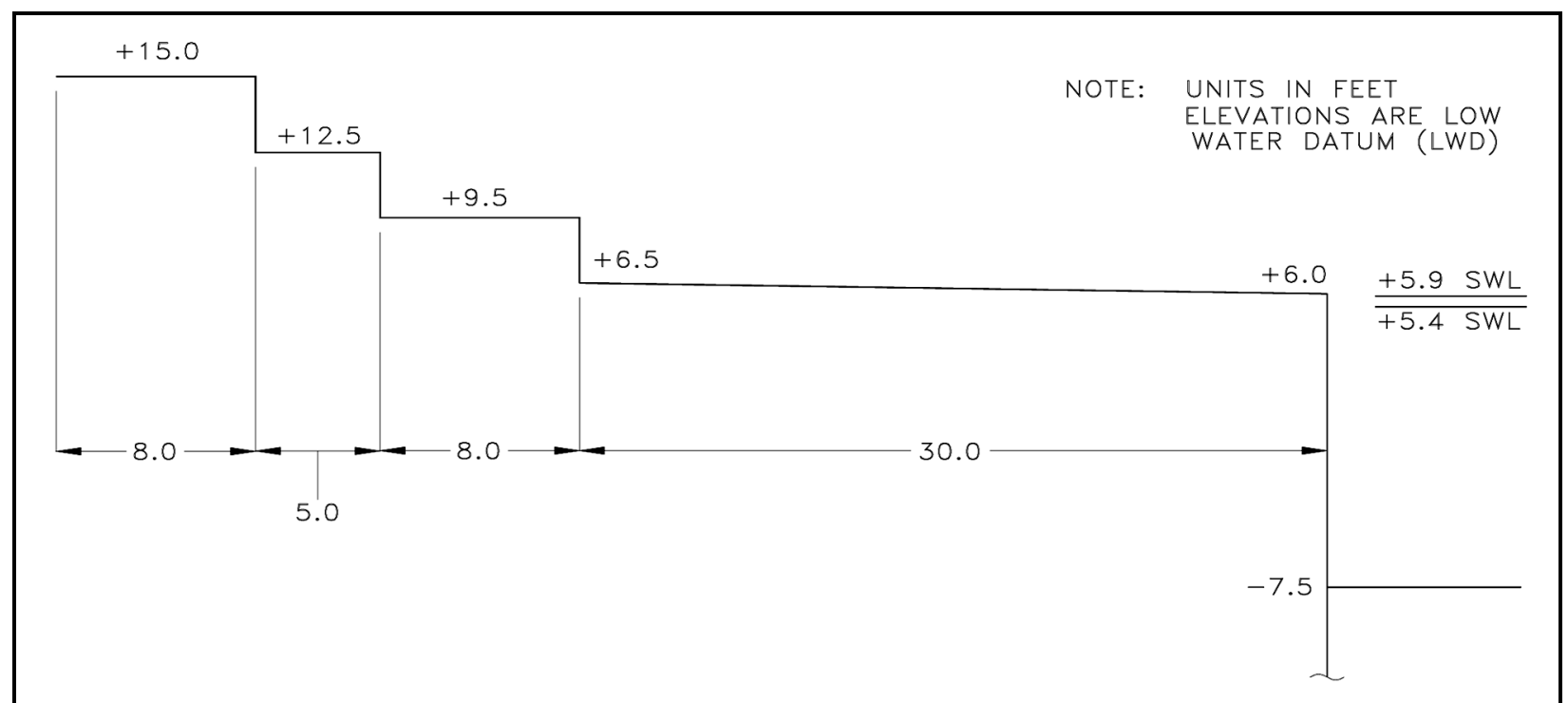

Figure 22. Cross-section of Plan E 
Plan F. Plan F included the low seawall elevation at $+1.22 \mathrm{~m}(+4.0 \mathrm{ft})$, as in Plan D, as well as the same promenade and first three steps; but the fourth step in Plan F was at an elevation of $+5.03 \mathrm{~m}(+16.5 \mathrm{ft})$ rather than the elevation of $+5.49 \mathrm{~m}(+18.0 \mathrm{ft})$ used in Plan D. Lowering the elevation of the top step increased the overtopping rate to $0.049 \mathrm{~m}^{3} / \mathrm{s} / \mathrm{m}\left(0.53 \mathrm{ft}^{3} / \mathrm{s} / \mathrm{ft}\right)$ from $0.035 \mathrm{~m}^{3} / \mathrm{s} / \mathrm{m}$ $\left(0.38 \mathrm{ft}^{3} / \mathrm{s} / \mathrm{ft}\right)$ on Plan D. Plan F is illustrated in Figure 23.

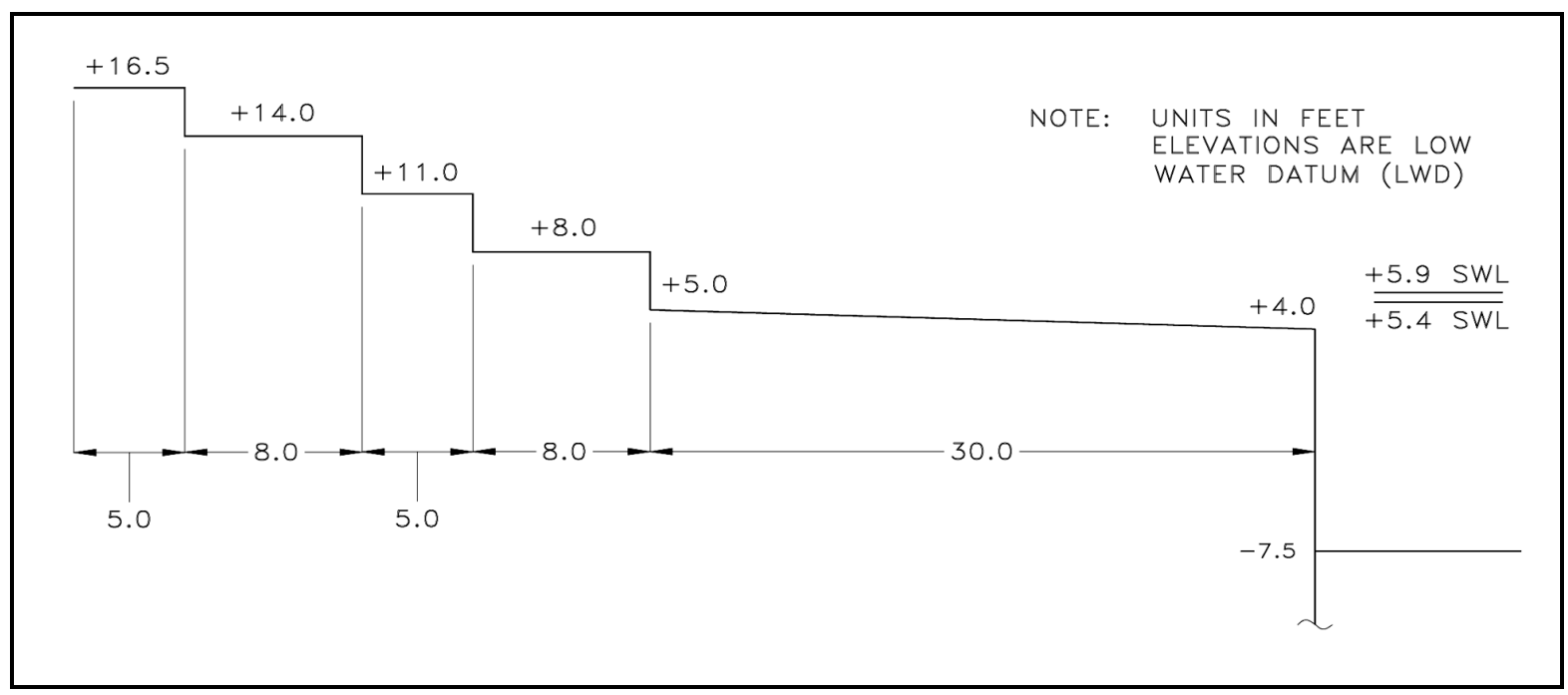

Figure 23. Cross-section of Plan $\mathrm{F}$

Plan G. Plan G was identical to Plans D and F on the promenade and first three steps, but Plan G did not have a fourth step. Crest elevation (top of third step) was $+4.27 \mathrm{~m}(+14.0 \mathrm{ft})$, and overtopping rate was $0.112 \mathrm{~m}^{3} / \mathrm{s} / \mathrm{m}(1.21$ $\left.\mathrm{ft}^{3} / \mathrm{s} / \mathrm{ft}\right)$. The addition of a $0.76-\mathrm{m}$-high $(2.5 \mathrm{ft})$ step in Plan F reduced the overtopping by more than half to $0.049 \mathrm{~m}^{3} / \mathrm{s} / \mathrm{m}\left(0.53 \mathrm{ft}^{3} / \mathrm{s} / \mathrm{ft}\right)$, and the taller 1.22$\mathrm{m}$-high (4.0-ft-high) fourth step in Plan D reduced the overtopping by nearly 70 percent over Plan G. Plan G is illustrated in Figure 24.

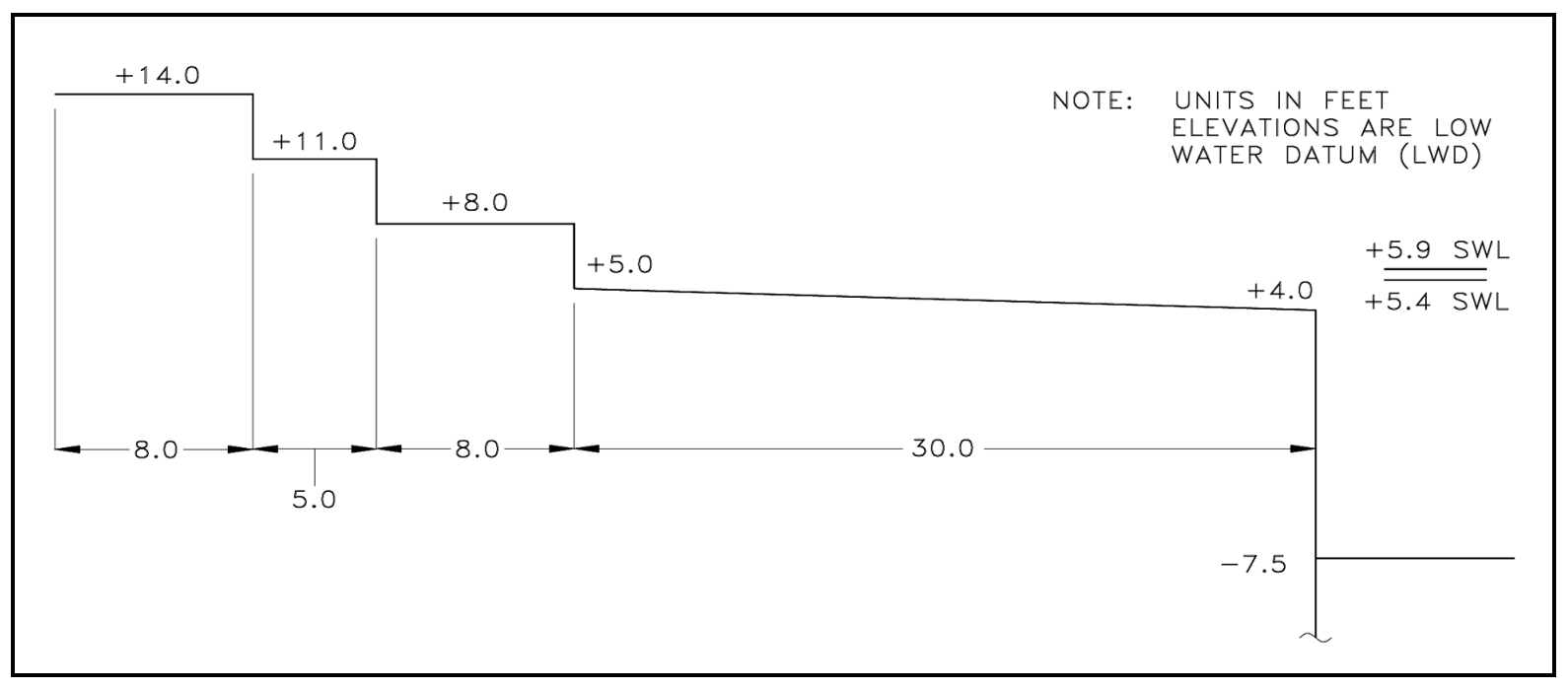

Figure 24. Cross-section of Plan G 
Plan H. Plan $\mathrm{H}$ was almost identical to Plan E, including the seawall elevation of $+1.83 \mathrm{~m}(+6.0 \mathrm{ft}), 9.14-\mathrm{m}$-wide promenade $(30.0 \mathrm{ft})$, and three steps leading to a crest elevation of $+4.57 \mathrm{~m}(+15.0 \mathrm{ft})$. Plan $\mathrm{H}$ differed from Plan $\mathrm{E}$ by the addition of a concave recurve in the front of the top step. It was hoped that the recurve would help direct the overtopping sheet flow back out towards the lake and reduce overtopping. Observations of the recurve indicated that the recurve was too small to be effective and the overtopping sheets of water simply flowed over the recurve. There was no measurable reduction in overtopping rate compared to Plan E. Measured overtopping rate was $0.091 \mathrm{~m}^{3} / \mathrm{s} / \mathrm{m}\left(0.98 \mathrm{ft}^{3} / \mathrm{s} / \mathrm{ft}\right)$; Plan $\mathrm{H}$ is illustrated in Figure 25.

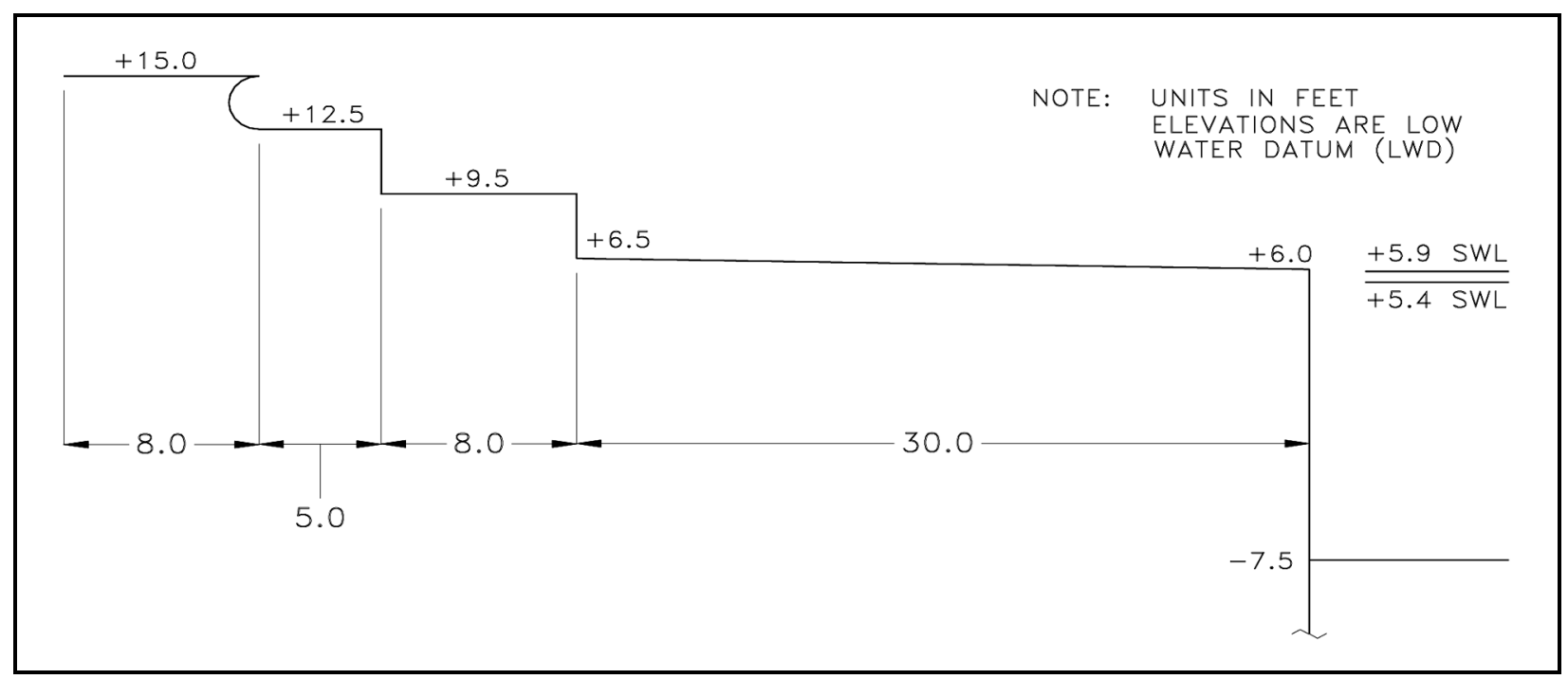

Figure 25. Cross-section of Plan $\mathrm{H}$

\section{Locally-preferred plan}

Overtopping rates determined from Plans A through $\mathrm{H}$ were considered along with safety and aesthetic concerns of the local sponsors to develop the locallypreferred plan (LPP). The LPP has a lakeward promenade elevation of $+1.83 \mathrm{~m}$ $(+6.0 \mathrm{ft})$. The $9.14-\mathrm{m}$ wide $(30-\mathrm{ft})$ promenade sloped from the top of the seawall to an elevation of $+2.13 \mathrm{~m}(+7.0 \mathrm{ft})$ at the base of the steps. The first two steps were each $2.44-\mathrm{m}$ wide $(8.0 \mathrm{ft})$ and at elevations $+3.05 \mathrm{~m}(+10.0 \mathrm{ft})$ and $+3.81 \mathrm{~m}$ $(+12.5 \mathrm{ft})$ at the lakeside edge. The third step was $1.52-\mathrm{m}$ wide $(5.0 \mathrm{ft})$ and at elevation $+4.57 \mathrm{~m}(+15.0 \mathrm{ft})$ at lakeside edge. All steps had a slope of $6.4 \mathrm{~mm}$ per $0.305 \mathrm{~m}$ (0.25 in per foot), or roughly 2 percent, towards the lake to improve drainage, and each step riser had a 10:1 slope upwards towards the lake to help reflect runup back towards the lake. Due to the small scale, the physical model did not replicate the 2 percent slope of the steps or the 10:1 slope of the step riser. The LPP as reproduced in the model is illustrated in Figure 26. 


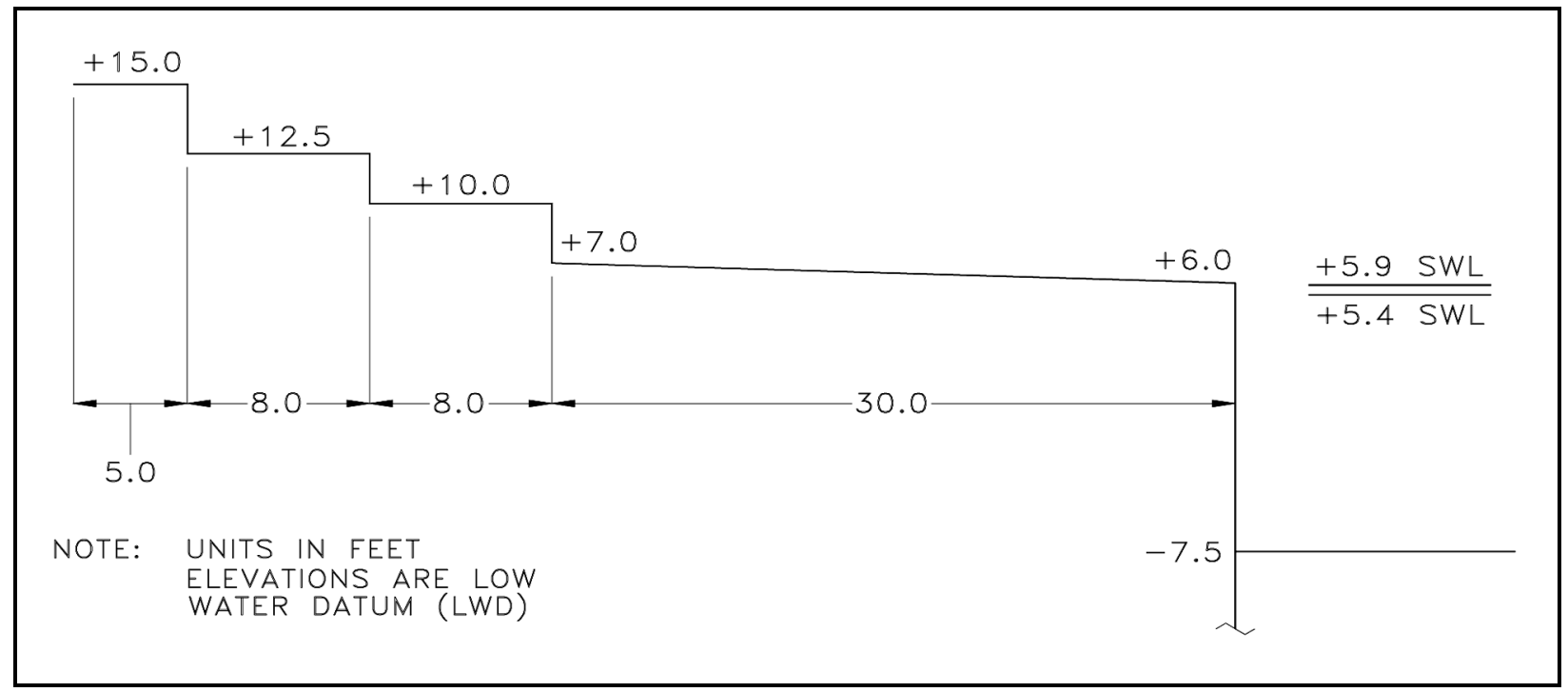

Figure 26. Cross-section of Locally Preferred Plan

\section{Phase II}

\section{LPP with storm wave height and wave period hydrograph}

Design storm conditions usually do not last for an extended period of time, but occur only at the peak of the design storm. Water levels due to storm surge, wave heights, and wave periods are constantly changing throughout the storm. It was therefore desired to select a hydrograph to represent the design storm and measure overtopping rates throughout the selected hydrograph. After examining wave hindcasts for the Chicago lakefront from WIS station M0001, LRC selected the February, 1979, storm as the representative hydrograph.

Wave periods determined from the wave hindcast were typically about $2 \mathrm{~s}$ shorter than wave periods measured at the offshore wave gauge. Hindcast wave periods were therefore increased by $2 \mathrm{~s}$ to determine the design storm conditions listed in Table 1. Similarly, all wave periods hindcast for the February, 1979, storm were increased by $2 \mathrm{~s}$ to develop the storm hydrograph. The adjusted storm hydrograph is illustrated in Figure 27. The adjusted wave periods are listed in Table 5 with the hindcast wave heights for the selected storm event.

The storm hydrograph shown in Figure 27 and listed in Table 5 was adjusted such that the peak of the storm matched the 10-year design storm conditions given in Table 1. As seen in Table 5, maximum significant wave height for the February, 1979, storm was $5.21 \mathrm{~m}$ (17.1 ft) with an adjusted wave period of 11 sec. Increasing the maximum wave height by 7.6 percent provided the desired 10 -year storm wave height of $5.61 \mathrm{~m}(18.4 \mathrm{ft})$, and the wave period associated with the maximum wave height was increased by 12.7 percent to yield the 10year storm wave period of $12.4 \mathrm{sec}$. All wave heights in the storm hydrograph 


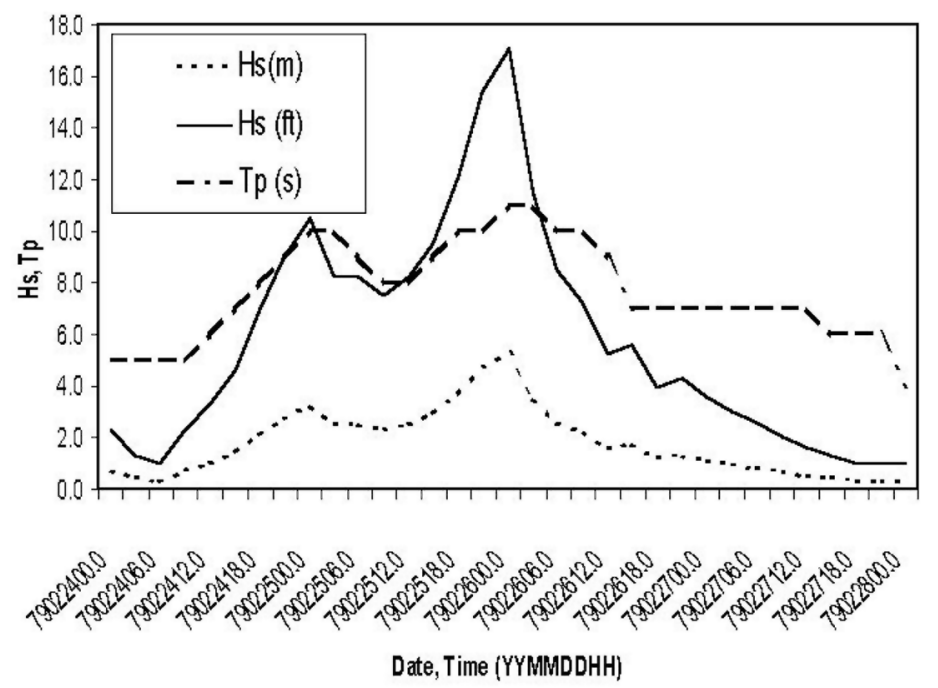

Figure 27. Adjusted storm hydrograph for February, 1979, storm

were therefore increased by 7.6 percent, and all wave periods were increased by 12.4 percent. The resulting storm hydrograph had the same shape as the original storm hydrograph, but conditions at the peak of the storm matched the 10 -year design storm conditions. The modified storm hydrograph is included in Table 5. For the physical model study, wave heights in the storm hydrograph were reproduced as the $\mathrm{H}_{\mathrm{m} 0}$ using a JONSWAP wave spectrum.

The wave period/wave height combinations at each three hour interval during the selected storm event were sorted in descending order by wave period and then by wave height. For a given wave period in the hydrograph, overtopping rates were determined for each successively lower wave height from the hydrograph until no measurable overtopping was collected. Smaller wave heights for the given period would also produce no measurable overtopping, and were not tested. Instead, testing continued with the largest wave height at the next shorter wave period.

Water level fluctuations during the selected storm were not included in the analysis. Instead, all wave height/wave period combinations were run at each of three water levels: $+1.07 \mathrm{~m}(+3.5 \mathrm{ft}),+1.43 \mathrm{~m}(+4.7 \mathrm{ft})$, and $+1.80 \mathrm{~m}(+5.9 \mathrm{ft})$. These water levels were selected by LRC.

The LPP was subjected to each of the wave height/wave period combinations in the modified hydrograph selected as representing the design storm. Three

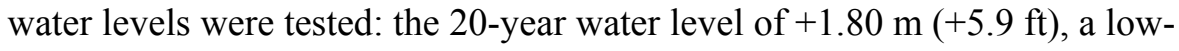
water level of $+1.07 \mathrm{~m}(+3.5 \mathrm{ft})$, and midway between the 20 -year water level and the low water level, or $+1.43 \mathrm{~m}(+4.7 \mathrm{ft})$. All combinations of wave height, period, and water level were tested with both the shallow-water toe at $-2.89 \mathrm{~m}$ ($7.5 \mathrm{ft})$ and the deep-water toe at $-5.03 \mathrm{~m}(-16.5 \mathrm{ft})$. The storm hydrograph, sorted by wave period and wave height and with measured overtopping rates, is given in Table 6 for the shallow-water toe and in Table 7 for the deep-water toe for each of the three water depths studied. 


\section{Table 5 \\ Selected Design Storm Hydrograph Wave Heights and Periods Adjusted to 10-year Design Storm}

\begin{tabular}{|c|c|c|c|c|}
\hline \multirow[b]{2}{*}{$\begin{array}{l}\text { Date and Time } \\
\text { YYMMDDHH }\end{array}$} & \multicolumn{2}{|c|}{ Hindcast Storm } & \multicolumn{2}{|c|}{ Storm Modified to 10 -year Level } \\
\hline & \begin{tabular}{|l} 
Wave Height \\
$\mathrm{H}_{\mathrm{s}}$ \\
$\mathrm{m}(\mathrm{ft})$ \\
\end{tabular} & $\begin{array}{l}\text { Wave Period } \\
T_{p} \\
s\end{array}$ & \begin{tabular}{|l} 
Wave Height \\
$\mathrm{H}_{\mathrm{o}}$ \\
$\mathrm{m}(\mathrm{ft})$ \\
\end{tabular} & $\begin{array}{l}\text { Wave Period } \\
T_{p} \\
\text { s }\end{array}$ \\
\hline 79022400 & $0.70(2.3)$ & 5 & $0.75(2.5)$ & 5.6 \\
\hline 79022403 & $0.40(1.3)$ & 5 & $0.43(1.4)$ & 5.6 \\
\hline 79022406 & $0.30(1.0)$ & 5 & $0.33(1.1)$ & 5.6 \\
\hline 79022409 & $0.70(2.3)$ & 5 & $0.75(2.5)$ & 5.6 \\
\hline 79022412 & $1.01(3.3)$ & 6 & $1.08(3.6)$ & 6.8 \\
\hline 79022415 & $1.40(4.6)$ & 7 & $2.26(4.9)$ & 7.9 \\
\hline 79022418 & $2.10(6.9)$ & 8 & $2.26(7.4)$ & 9.0 \\
\hline 79022421 & $2.71(8.9)$ & 9 & $2.92(9.6)$ & 10.1 \\
\hline 79022500 & $3.20(10.5)$ & 10 & $3.44(11.3)$ & 11.3 \\
\hline 79022503 & $2.50(8.2)$ & 10 & $2.69(8.8)$ & 11.3 \\
\hline 79022506 & $2.50(8.2)$ & 9 & $2.69(8.8)$ & 10.1 \\
\hline 79022509 & $2.29(7.5)$ & 8 & $2.46(8.1)$ & 9.0 \\
\hline 79022512 & $2.50(8.2)$ & 8 & $2.69(8.8)$ & 9.0 \\
\hline 79022515 & $2.90(9.5)$ & 9 & $3.12(10.2)$ & 10.1 \\
\hline 79022518 & 3.69 (12.1) & 10 & $3.97(13.0)$ & 11.3 \\
\hline 79022521 & $4.69(15.4)$ & 10 & $5.05(16.6)$ & 11.3 \\
\hline 79022600 & $5.21(17.1)$ & 11 & $5.61(18.4)$ & 12.4 \\
\hline 79022603 & $3.51(11.5)$ & 11 & $3.77(12.4)$ & 12.4 \\
\hline 79022606 & $2.59(8.5)$ & 10 & $2.79(9.1)$ & 11.3 \\
\hline 79022609 & $2.19(7.2)$ & 10 & $2.36(7.7)$ & 11.3 \\
\hline 79022612 & $1.58(5.2)$ & 9 & $1.71(5.6)$ & 10.1 \\
\hline 79022615 & $1.71(5.6)$ & 7 & $1.84(6.0)$ & 7.9 \\
\hline 79022618 & $1.19(3.9)$ & 7 & $1.28(4.2)$ & 7.9 \\
\hline 79022621 & $1.31(4.3)$ & 7 & $1.41(4.6)$ & 7.9 \\
\hline 79022700 & $1.10(3.6)$ & 7 & $1.18(3.9)$ & 7.9 \\
\hline 79022703 & $0.91(3.0)$ & 7 & 0.98 (3.2) & 7.9 \\
\hline 79022706 & $0.79(2.6)$ & 7 & $0.85(2.8)$ & 7.9 \\
\hline 79022709 & $0.61(2.0)$ & 7 & $0.66(2.2)$ & 7.9 \\
\hline \begin{tabular}{|l|}
79022712 \\
\end{tabular} & $0.49(1.6)$ & 7 & $0.52(1.7)$ & 7.9 \\
\hline 79022715 & $0.40(1.3)$ & 6 & $0.43(1.4)$ & 6.8 \\
\hline 79022718 & $0.30(1.0)$ & 6 & $0.33(1.1)$ & 6.8 \\
\hline 79022721 & $0.30(1.0)$ & 6 & $0.33(1.1)$ & 6.8 \\
\hline \begin{tabular}{|l|}
79022800 \\
\end{tabular} & $0.30(1.0)$ & 4 & $0.33(1.1)$ & 4.5 \\
\hline
\end{tabular}




\begin{tabular}{|c|c|c|c|c|}
\hline \multicolumn{5}{|c|}{$\begin{array}{l}\text { Table } 6 \\
\text { Overtopping Rates (Prototype) for the Locally Preferred Plan with } \\
\text { Sheetpile Toe at }-2.29 \mathrm{~m}(-7.5 \mathrm{ft})\end{array}$} \\
\hline \multicolumn{2}{|c|}{ Wave Conditions } & \multirow{2}{*}{\multicolumn{3}{|c|}{$\begin{array}{l}\text { Overtopping Rate, } \mathrm{m}^{3} / \mathrm{s} / \mathrm{m}\left(\mathrm{ft}^{3} / \mathrm{s} / \mathrm{ft}\right) \\
\text { SWL, } \mathrm{m} \text { (ft) }\end{array}$}} \\
\hline \multirow{2}{*}{$\begin{array}{l}\text { Wave Period } \\
\mathrm{T}_{\mathrm{p}} \\
\mathrm{s} \\
\end{array}$} & \multirow{2}{*}{$\begin{array}{l}\text { Wave Height } \\
\mathrm{H}_{\circ} \\
\mathrm{m}(\mathrm{ft})\end{array}$} & & & \\
\hline & & $+1.07(+3.5)$ & $+1.43(+4.7)$ & $+1.80(+5.9)$ \\
\hline \multirow[b]{2}{*}{12.4} & $5.61(18.4)$ & $0.011(0.12)$ & $0.037(0.40)$ & $0.084(0.90)$ \\
\hline & $3.78(12.4)$ & $0.009(0.10)$ & $0.025(0.27)$ & $0.060(0.65)$ \\
\hline \multirow[b]{6}{*}{11.3} & $5.06(16.6)$ & $0.013(0.14)$ & $0.035(0.38)$ & $0.072(0.77)$ \\
\hline & $3.96(13.0)$ & $0.009(0.097)$ & $0.024(0.25)$ & $0.061(0.66)$ \\
\hline & $3.44(11.3)$ & $0.007(0.074)$ & $0.016(0.17)$ & $0.046(0.50)$ \\
\hline & $2.77(9.1)$ & $0.004(0.041)$ & $0.010(0.11)$ & $0.025(0.26)$ \\
\hline & $2.68(8.8)$ & $0.003(0.033)$ & $0.009(0.096)$ & $0.024(0.26)$ \\
\hline & $2.35(7.7)$ & $0.002(0.022)$ & $0.004(0.044)$ & $0.010(0.11)$ \\
\hline \multirow[b]{4}{*}{10.1} & $3.11(10.2)$ & $0.004(0.039)$ & $0.010(0.11)$ & $0.029(0.31)$ \\
\hline & $2.93(9.6)$ & $0.002(0.026)$ & $0.008(0.083)$ & $0.023(0.25)$ \\
\hline & $2.68(8.8)$ & $0.002(0.019)$ & $0.005(0.058)$ & $0.016(0.17)$ \\
\hline & $1.71(5.6)$ & $0.000(0.001)$ & $0.000(0.001$ & $0.000(0.005)$ \\
\hline \multirow[b]{3}{*}{9.0} & $2.68(8.8)$ & $0.000(0.004)$ & $0.001(0.010)$ & $0.005(0.049)$ \\
\hline & $2.47(8.1)$ & $0.000(0.002)$ & $0.001(0.007)$ & $0.002(0.024)$ \\
\hline & $2.26(7.4)$ & $0.000(0.002)$ & $0.000(0.003)$ & $0.001(0013)$ \\
\hline 7.9 & $1.83(6.0)$ & $0.000(0.000)$ & $0.000(0.000)$ & $0.000(0.00)$ \\
\hline
\end{tabular}

\begin{tabular}{|c|c|c|c|c|}
\hline $\begin{array}{l}\text { Table } 7 \\
\text { Overtoppi } \\
\text { Sheetpile } \\
\end{array}$ & $\begin{array}{l}\text { Rates (Pro } \\
\text { at }-5.03 \text { n }\end{array}$ & $\begin{array}{l}\text { (pe) for th } \\
16.5 \mathrm{ft})\end{array}$ & cally-Pre & d Plan with \\
\hline Wave Conditi & & Overtopping $\mathrm{F}$ & $\mathrm{m}^{3} / \mathrm{s} / \mathrm{m}\left(\mathrm{ft}^{3} / \mathrm{s} / \mathrm{f}\right.$ & \\
\hline Wave Period & Wave Height & SWL, m (ft) & & \\
\hline & & $+1.07(+3.5)$ & $+1.43(+4.7)$ & $+1.80(+5.9)$ \\
\hline & $5.61(18.4)$ & $0.025(0.27)$ & $0.054(0.59)$ & $0.079(0.85)$ \\
\hline 12.4 & $3.78(12.4)$ & $0.013(0.14)$ & $0.036(0.39)$ & $0.060(0.64)$ \\
\hline & $5.06(16.6)$ & $0.020(0.21)$ & $0.039(0.42)$ & $0.075(0.81)$ \\
\hline & $3.96(13.0)$ & $0.016(0.17)$ & $0.025(0.27)$ & $0.064(0.69)$ \\
\hline & $3.44(11.3)$ & $0.009(0.10)$ & $0.023(0.24)$ & $0.051(0.55)$ \\
\hline & $2.77(9.1)$ & $0.005(0.055)$ & $0.013(0.14)$ & $0.027(0.29)$ \\
\hline & $2.68(8.8)$ & $0.006(0.062)$ & $0.010(0.11)$ & $0.019(0.20)$ \\
\hline 11.3 & $2.35(7.7)$ & $0.002(0.023)$ & $0.004(0.048)$ & $0.011(0.11)$ \\
\hline & $3.11(10.2)$ & $0.006(0.068)$ & $0.012(0.13)$ & $0.028(0.30)$ \\
\hline & $2.93(9.6)$ & $0.006(0.063)$ & $0.010(0.11)$ & $0.021(0.23)$ \\
\hline & $2.68(8.8)$ & $0.003(0.029)$ & $0.007(0.080)$ & $0.013(0.14)$ \\
\hline 10.1 & $1.71(5.6)$ & $0.000(0.003)$ & $0.000(0.001)$ & $0.000(0.000)$ \\
\hline & $2.68(8.8)$ & $0.001(0.012)$ & $0.002(0.025)$ & $0.004(0.047)$ \\
\hline & $2.47(8.1)$ & $0.001(0.007)$ & $0.001(0.009)$ & $0.002(0.023)$ \\
\hline 9.0 & $2.26(7.4)$ & $0.000(0.000)$ & $0.001(0.009)$ & $0.001(0.007)$ \\
\hline 7.9 & $1.83(6.0)$ & $0.000(0.000)$ & $0.000(0.000)$ & $0.000(0.000)$ \\
\hline Total & & $0.112(1.21)$ & $0.240(2.58)$ & $0.455(4.90)$ \\
\hline
\end{tabular}




\section{Parameter effects on overtopping rate}

Regression analysis was used to quantify the effects of various parameters affecting the overtopping rate. Input data included overtopping rates for each experiment with the LPP at each of the toe depths tested. Parameters input to the regression analysis included depth at structure toe relative to LWD, freeboard at top of steps relative to LWD, and incident wave conditions. The selected equation was

$$
100 q+1=C_{0} \exp \left(C_{1} R+C_{2} D\right)
$$

where $q$ is dimensional overtopping rate in $\mathrm{cfs} / \mathrm{ft}, C_{0}, C_{1}$, and $C_{2}$ are regression coefficients, $R$ is dimensionless relative freeboard defined as

$$
R=\frac{h_{\text {crest }}-S W L}{\sqrt[3]{H_{0}^{2} L_{0}}}
$$

where $h_{\text {crest }}$ is elevation of revetment crest referenced to LWD, $L_{0}$ is deepwater wavelength defined as

$$
L_{0}=\frac{g T_{p}^{2}}{2 \pi}
$$

where $g$ is acceleration of gravity, and $D$ is dimensionless relative depth defined as

$$
D=\frac{S W L-h_{t o e}}{\left(H_{m 0}\right)_{t o e}}
$$

where $h_{\text {toe }}$ is elevation at structure toe referenced to LWD and $\left(H_{m 0}\right)_{\text {toe }}$ is wave height at structure toe. Note that $D$ will always be a positive value. Wave height at structure toe was determined by the shoaling equation of Hughes (1984) ${ }^{1}$,

$$
\left[\frac{H_{0}}{L_{p}^{3 / 4}}\right]_{o}=\left[\frac{H_{m 0}}{L_{p}^{3 / 4}}\right]_{t o e}
$$

where the subscripts $o$ and toe refer to offshore and at the structure, respectively, and $L_{p}$ is wave length based on linear wave theory for local depth and period of peak energy density. Offshore values were based on the prototype wave gauge at a depth of $-13.1 \mathrm{~m}(-43 \mathrm{ft})$.

${ }^{1}$ Hughes, S. A. 1984. "The TMA shallow-water spectrum description and applications," Technical Report CERC-84-7, Waterways Experiment Station, Vicksburg, MS. 
Equation 1 was linearized by taking the natural logarithm of each side, yielding

$$
\ln (100 q+1)=\ln C_{0}+C_{1} R+C_{2} D
$$

A weight function of $(100 q+1)$ was used to give more emphasis to higher overtopping rates. Values of the regression coefficients with standard error and $95 \%$ confidence limits are shown in Table 8.

\section{Table 8 \\ Regression Coefficients with Standard Error and 95 percent Confidence Limits}

\begin{tabular}{|l|l|l|l|l|}
\hline \hline Coefficient & Value & Standard Error & Lower 95\% & Upper 95\% \\
\hline \hline $\ln \left(\boldsymbol{C}_{0}\right)$ & 6.860 & 0.172 & 6.517 & 7.202 \\
\hline $\boldsymbol{C}_{1}$ & -18.994 & 0.821 & -20.626 & -17.363 \\
\hline $\boldsymbol{C}_{2}$ & 0.262 & 0.072 & 0.118 & 0.406 \\
\hline
\end{tabular}

Solving the regression equation for dimensional (cfs/ft) overtopping rate yields

$$
q=\frac{953 \exp (-18.99 R+0.262 D)-1}{100}
$$

The correlation coefficient (statistical $R^{2}$, not to be confused with relative freeboard) obtained was better than 0.90. Ranges of parameters used in Equation 7 are given in Table 9. Comparison of predicted and measured overtopping rates for the LPP under the storm hydrograph is shown in Figure 28. Note that overtopping rates in Equation 7 must be in English units of $\mathrm{cfs} / \mathrm{ft}$ due to the weighting function.

\section{Table 9}

Range of Parameters in LPP Storm Regression Equation

\begin{tabular}{||l|l|l||}
\hline \hline Dimensional Parameter & Minimum & Maximum \\
\hline \hline$\left(h_{\text {crest }}-\mathrm{SWL}\right) \mathrm{m}(\mathrm{ft})$ & $2.77(9.1)$ & $3.50(11.5)$ \\
\hline$H_{\mathrm{mo}}(\mathrm{toe}) \mathrm{m}(\mathrm{ft})$ & $1.05(3.5)$ & $4.30(14.1)$ \\
\hline$H_{0} \mathrm{~m}(\mathrm{ft})$ & $1.71(5.6)$ & $5.61(18.4)$ \\
\hline$L_{o} \mathrm{~m}(\mathrm{ft})$ & $126.4(415)$ & $239.9(787)$ \\
\hline$\left(\mathrm{SWL}-h_{\text {toe }}\right) \mathrm{m}(\mathrm{ft})$ & $3.35(11.0)$ & $6.83(22.4)$ \\
\hline$T_{p} \mathrm{~S}$ & 9.0 & 12.4 \\
\hline \hline Non-dimensional Parameter & Minimum & Maximum \\
\hline \hline$D$ & .99 & 4.91 \\
\hline$R$ & .14 & .45 \\
\hline
\end{tabular}




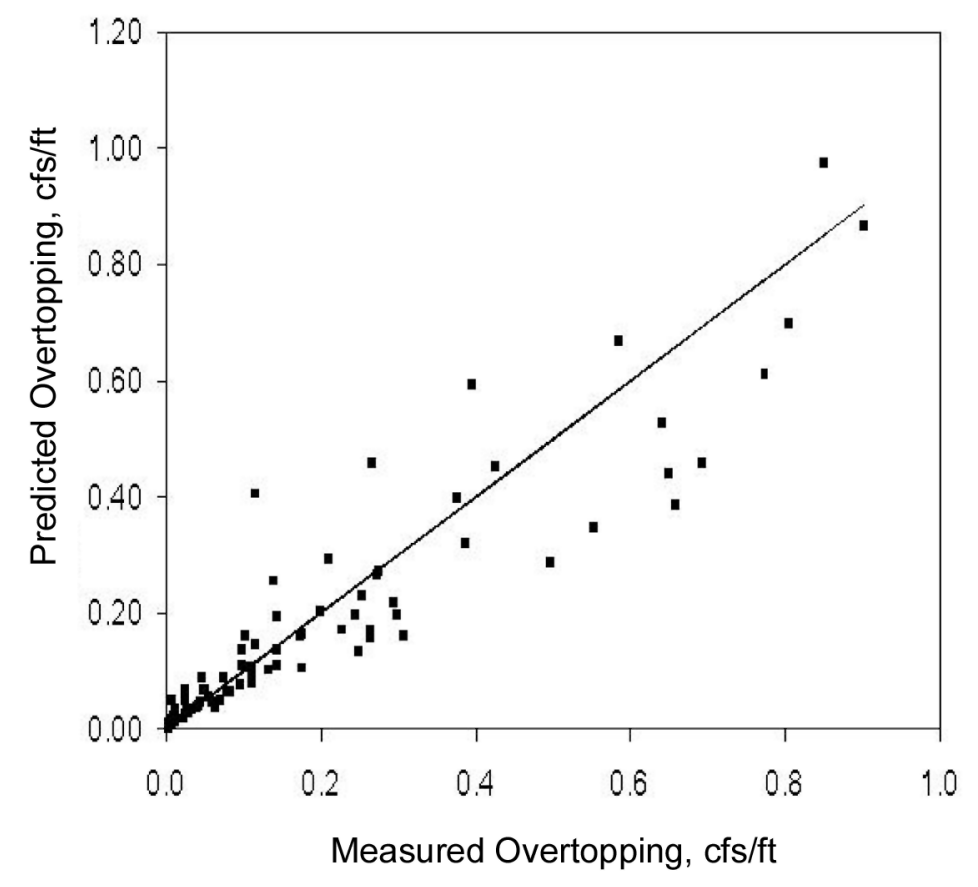

Figure 28. Predicted vs measured overtopping for Phase II regression equation

\section{Toe stability}

Design for toe protection to the revetment was developed by LRC and tested in the physical model. Two designs were prepared, one each for the shallowwater toe and the deeper-water toe. The shallow-water toe and deeper-water toe designs are illustrated in Figures 29 and 30, respectively.

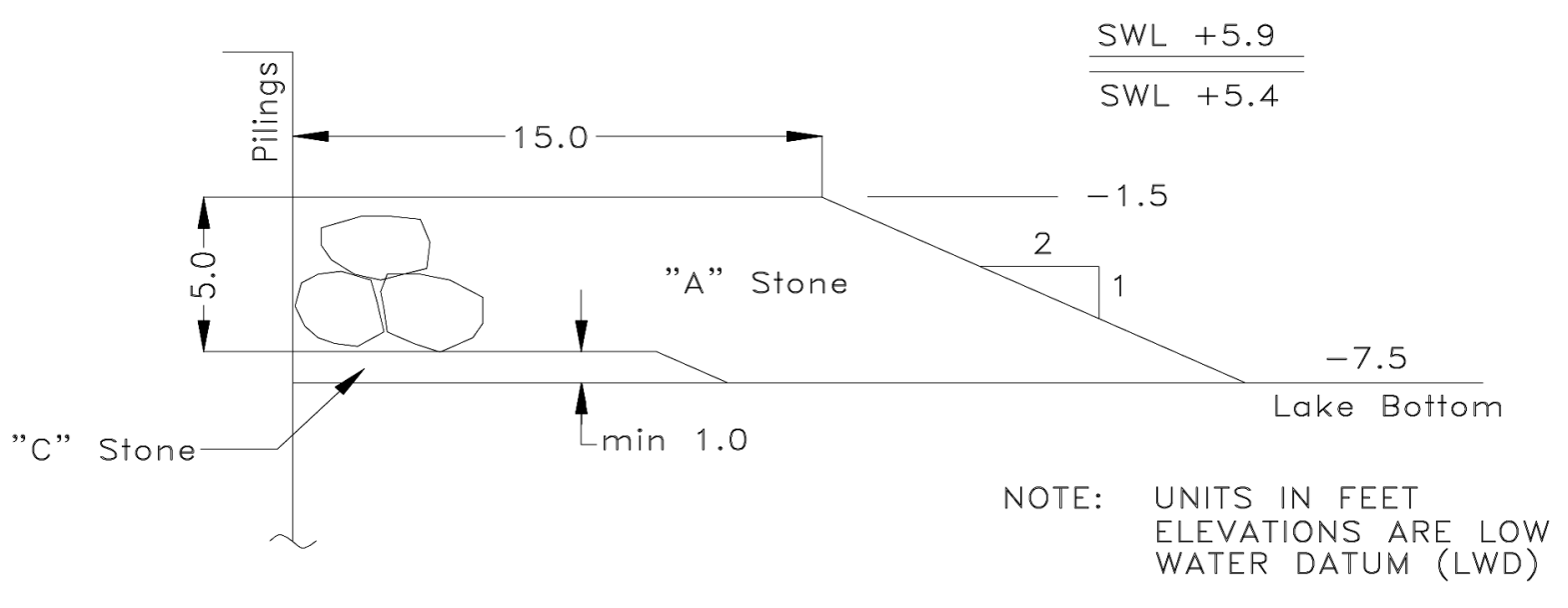

Figure 29. Cross-section of shallow-water toe protection 


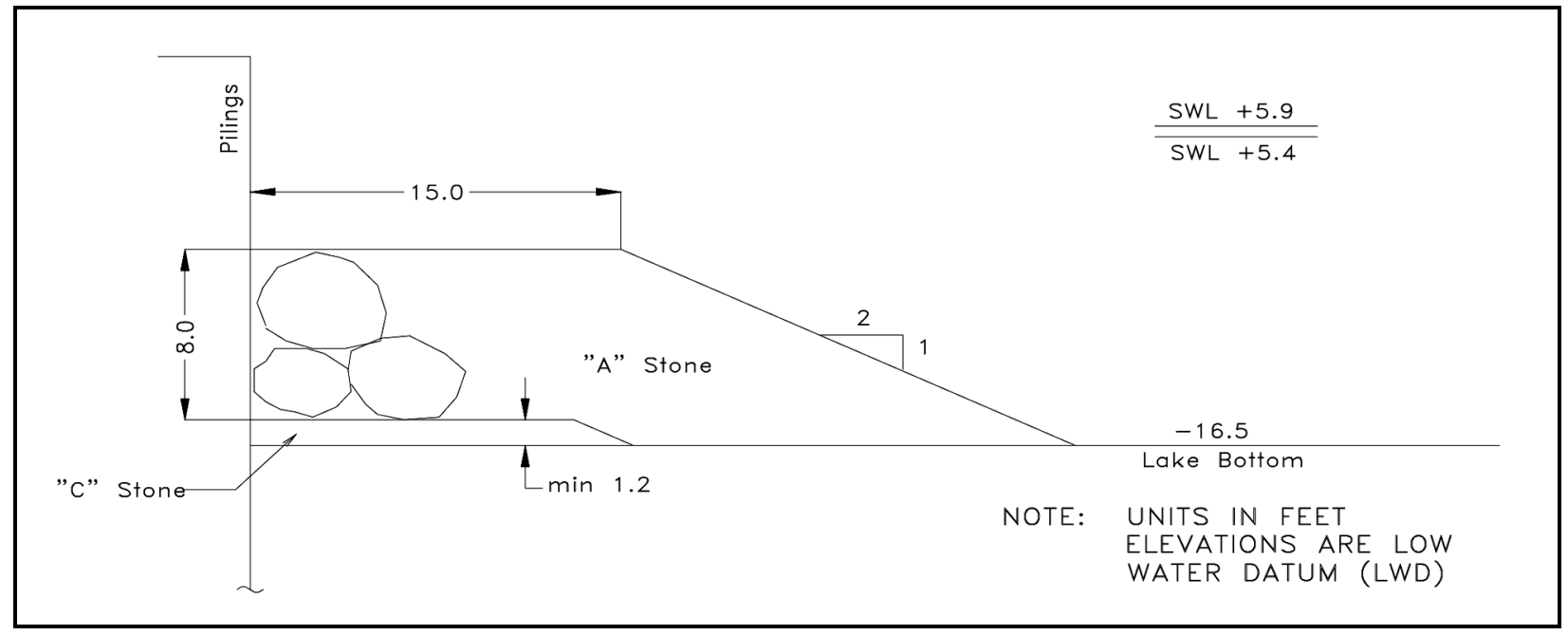

Figure 30. Cross-section of deeper-water toe protection

The shallow-water toe had a toe depth of $-2.29 \mathrm{~m}(-7.5 \mathrm{ft})$. Scour protection for the shallow-water toe required 1.8- to 4.5-tonne stone (2- to 5-tons) ("A" stone) to an elevation of $-0.46 \mathrm{~m}(-1.5 \mathrm{ft})$, width of $4.57 \mathrm{~m}(15.0 \mathrm{ft})$ on top, then a $1: 2$ slope to lake bottom. A minimum 0.30 -m-thick (1.0-ft-thick) bedding layer of 0.5 - to $23-\mathrm{kg}$ stone (1- to $50-\mathrm{lbs}$ ) ("C" $\mathrm{C}$ " stone) was placed under the first $4.57 \mathrm{~m}$ $(15.0 \mathrm{ft})$ of the toe protection.

The deeper-water toe had a toe depth of $-5.03 \mathrm{~m}(-16.5 \mathrm{ft})$. Scour protection for the deep-water toe used 2.7- to 8.2-tonnes (3- to 9-tons) stone to an elevation of $-2.22 \mathrm{~m}(-7.3 \mathrm{ft})$, width of $4.57 \mathrm{~m}(15.0 \mathrm{ft})$, then a 1:2 slope to lake bottom. A minimum 0.37 -m-thick (1.2-ft-thick) bedding layer of 0.5 - to $45-\mathrm{kg}$ (1- to $100 \mathrm{lb}$ ) stone was placed under the first $4.57 \mathrm{~m}(15.0 \mathrm{ft})$ of the toe protection.

Observations in the physical model indicated that most of the damage to the revetment toe was caused by the downrush of water spilling off the revetment during tests at the low water levels. Damage was more severe during tests with the 10-year water level and 20-year wave height and period than at the 20-year water level with 10-year wave height and period due mainly to the shallower water at the 10-year water level. Wave action would pass over the top of the seawall onto the promenade with little effect on the structure toe. Return flow of water running off the promenade, plunging over the crest of the seawall, and impacting vertically on the revetment toe caused movement of the toe stone directly in front of the revetment. Significant damage to the toe occurred only during experiments with the 20 -year storm generated at the 10 -year water level.

Damage to the toe protection encompassed the entire top layer of stone (2-layer construction), resulting in a single wide layer of stone. The single layer of stone generally became tightly packed and showed good stability.

Because of the damage to the toe protection on the shallow-water toe, the armor stone from the shallow-water toe protection was removed and replaced with the heavier stone recommended for the deeper-water toe protection. In 
addition, the plywood under the toe stone was roughened by gluing a thin layer of sand to the area under the armor stone. In the prototype, it is expected that the armor stone will become partially embedded in the sandy bottom of the lake in front of the revetment, but stones were not embedded on the model.

Use of the larger stone size for the toe protection provided suitable stability against erosion, but was rejected by the local sponsors because of the height of the toe berm. The local sponsors were concerned that people may be hurt by diving onto rocks at a shallow level, and requested that all toe stone be kept below a maximum elevation of $-0.61 \mathrm{~m}(-2.0 \mathrm{ft})$. Allowing for a variation of 0.61 $\mathrm{m}(2.0 \mathrm{ft})$ in elevation of stones placed underwater, the maximum elevation of the stones must be kept below $-1.22 \mathrm{~m}(-4.0 \mathrm{ft})$.

Experiments were conducted in the physical model in front of the LPP with the shallow water toe using a single layer of the smaller 1.8- to 4.5-tonne stone (2- to 5-ton). Minor movement of individual stones was observed (rocking, some rolling), but the single layer remained intact. The single layer of armor stone was placed by hand in a manner replicating prototype construction. It is expected that movement of the stones on the prototype would cause the stones to become more densely packed than is practical during initial placement, and that openings would occur directly in front of the seawall. Monitoring of the toe protection will be required, and additional stone will need to be placed in front of the seawall should gaps develop.

\section{Phase III: Diversey to Fullerton}

\section{Overtopping rates}

The City expressed concern over the crest elevation of the LPP for the Chicago lakefront reach extending roughly between the streets of Diversey on the north and Fullerton on the south. Low elevations of the ground shoreward of the proposed revetment would result in restricted visibility of the lake if the revetment were constructed to the LPP elevation of $+4.57 \mathrm{~m}(+15.0 \mathrm{ft})$. An additional set of experiments were therefore conducted using the same wave flume as in Phase I and Phase II of this study. The experiments measured overtopping rates for various low-crested revetment configurations with and without enlarged toe berms or an offshore breakwater. All experiments in Phase III of this study were conducted with the design storm determined in Phase I of this study (10-year storm at the 20-year water level). The Diversey to Fullerton reach is shown in Figure 3.

Since the completion of Phases I and II of this study, new software had been installed for the wave board controller and data acquisition. The LPP was therefore re-installed in the flume to confirm that no significant changes in wave generation or data collection and processing had occurred. An overtopping rate of $0.85 \mathrm{cfs} / \mathrm{ft}$ was measured for the design storm condition, matching the 0.85 $\mathrm{cfs} / \mathrm{ft}$ measured during the Phase I experiments. 
Bathymetry lakeward of the Diversey to Fullerton reach was similar to bathymetry off Reach 4 . All experiments were therefore conducted with a structure toe depth of $-5.03 \mathrm{~m}(-16.5) \mathrm{ft}$. Lakeward edge of the promenade in all experiments was $+1.83 \mathrm{~m}(+6.0 \mathrm{ft})$.

Plan A from Phase I was installed in the flume with the original toe berm width of $4.57 \mathrm{~m}(15.0 \mathrm{ft})$. The measured overtopping rate was considered unacceptably high. In an effort to reduce the overtopping rate without raising crest elevation, the toe berm was increased to a width of $16.76 \mathrm{~m}(55.0-\mathrm{ft})$. Additional experiments were conducted with toe berms that were 39.6-m (130-ft) wide and $27.43-\mathrm{m}(90.0-\mathrm{ft})$ wide. Overtopping rates for each of these experiments are given in Table 10. Details of the Plan A cross-sections as used in the Diversey to Fullerton experiments are shown in Figure 31.

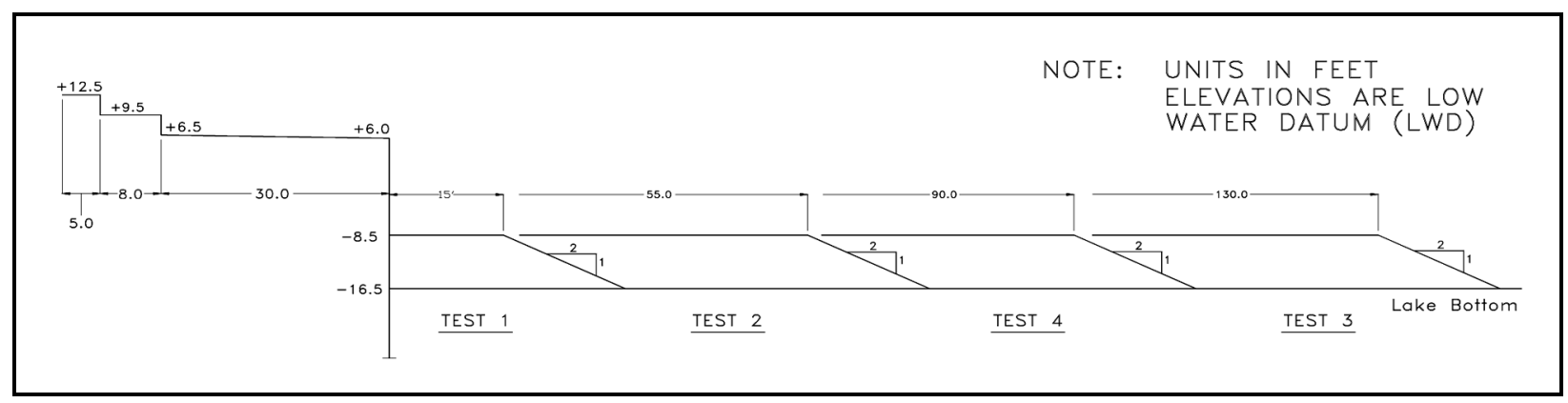

Figure 31. Cross-section of Plan A with toe berms

Whereas Plan A had a 9.14-m-wide (30.0-ft) promenade and 2 steps leading to a crest elevation of $+3.81 \mathrm{~m}(+12.5 \mathrm{ft})$, Plan 1 included a $7.92-\mathrm{m}$-wide $(26.0-\mathrm{ft})$ promenade and 4 steps leading to the crest. Step widths were $1.52 \mathrm{~m}(5.0 \mathrm{ft})$ for the first step up from the promenade, $2.44 \mathrm{~m}(8.0 \mathrm{ft})$ for the second step, $1.52 \mathrm{~m}$ $(5.0 \mathrm{ft})$ for the third step, and $3.35 \mathrm{~m}(11.0 \mathrm{ft})$ on the crest. On Plan 1, layers were added to the top step to change the crest elevation. Overtopping rates were determined for crest elevations of $+3.81,+4.02$, and $+4.24 \mathrm{~m}(+12.5,+13.2$, and $+13.9 \mathrm{ft})$, each with both a $9.14-\mathrm{m}$-wide $(30.0-\mathrm{ft})$ toe berm at crest elevation $-0.61 \mathrm{~m}(-2.0 \mathrm{ft})$ and a $16.76-\mathrm{m}$-wide $(55.0-\mathrm{ft})$ toe berm with a crest elevation of $-0.61 \mathrm{~m}(-2.0 \mathrm{ft})$. Plan 1 is illustrated in Figure 32.

Plan 2 had a crest elevation of $+3.81 \mathrm{~m}(+12.5 \mathrm{ft})$, a $7.92-\mathrm{m}$-wide $(26.0-\mathrm{ft})$ promenade and a $7.62-\mathrm{m}$-wide $(25.0-\mathrm{ft})$ promenade. Overtopping rates were determined for Plan 2 with toe berm widths of 4.57, 9.14, 16.76, and $27.43 \mathrm{~m}$ $(15.0,30.0,55.0$, and $90.0 \mathrm{ft})$. Cross-sections of Tests 1 through 4 with Plan 2 are illustrated in Figure 33.

Additional experiments added an offshore breakwater to Plan 2. The offshore breakwater had a crest width of $3.05 \mathrm{~m}(10.0 \mathrm{ft})$ with 1:1.5 side slopes.

Depending on construction method chosen for the prototype reef, location of the reef toe may be uncertain; therefore the reef location was designated by distance from revetment to the midpoint of the reef crest which was located $33.5 \mathrm{~m}$ (110 ft) offshore (this differs from earlier experiments with Plan A3). 


\begin{tabular}{|c|c|c|c|c|c|c|c|c|c|c|}
\hline \multicolumn{11}{|c|}{$\begin{array}{l}\text { Table } 10 \\
\text { Overtopping Rates for Phase III experiments with Promenade Elevation at }+1.83 \mathrm{~m}(+6.0 \mathrm{ft}) \text { and Revetment Toe } \\
\text { Elevation at }-5.03 \mathrm{~m}(-16.5 \mathrm{ft}) \text { (Depths are LWD) }\end{array}$} \\
\hline Plan & Test & $\begin{array}{l}\text { No. } \\
\text { Steps }\end{array}$ & $\begin{array}{l}\text { No. of } \\
\text { Promen- } \\
\text { ades }\end{array}$ & $\begin{array}{l}\text { Revetment } \\
\text { Crest } \\
\text { Elevation } \\
\text { m (ft) }\end{array}$ & \begin{tabular}{|l} 
Promenade \\
Width \\
$\mathrm{m}(\mathrm{ft})$ \\
\end{tabular} & $\begin{array}{l}\text { Toe Berm } \\
\text { Elevation } \\
\mathrm{m}(\mathrm{ft})\end{array}$ & \begin{tabular}{|l} 
Toe Berm \\
Width \\
m (ft)
\end{tabular} & $\begin{array}{l}\text { Distance from } \\
\text { Promenade to } \\
\text { Offshore } \\
\text { Breakwater } \\
\text { m (ft) }\end{array}$ & \begin{tabular}{|l} 
Offshore \\
Breakwater \\
Crest \\
Elevation \\
$\mathrm{m}(\mathrm{ft})$ \\
\end{tabular} & $\begin{array}{l}\text { Over- } \\
\text { topping } \\
\text { Rate } \\
\mathrm{m}^{3} / \mathrm{s} / \mathrm{m}(\mathrm{cfs} / \mathrm{ft})\end{array}$ \\
\hline LPP & 1 & 3 & 1 & $4.57(15.0)$ & $9.14(30.0)$ & $-0.61(-2.0)$ & $4.6(15)$ & & & $0.079(0.85)$ \\
\hline \multirow[b]{4}{*}{ Plan A } & 1 & 2 & 1 & $3.81(12.5)$ & $9.14(30.0)$ & $-0.61(-2.0)$ & $4.6(15)$ & & & $0.162(1.74)$ \\
\hline & 2 & 2 & 1 & $3.81(12.5)$ & $9.14(30.0)$ & $-0.61(-2.0)$ & $16.8(55)$ & & & $0.144(1.55)$ \\
\hline & 3 & 2 & 1 & $3.81(12.5)$ & $9.14(30.0)$ & $-0.61(-2.0)$ & $39.6(130)$ & & & $0.085(0.91)$ \\
\hline & 4 & 2 & 1 & $3.81(12.5)$ & $9.14(30.0)$ & $-0.61(-2.0)$ & $27.4(90)$ & & & $0.128(1.38)$ \\
\hline \multirow[b]{8}{*}{ Plan 1} & 1 & 4 & 1 & $3.81(12.5)$ & $7.92(26.0)$ & $-0.61(-2.0)$ & $9.1(30)$ & & & $0.156(1.68)$ \\
\hline & 2 & 4 & 1 & $4.02(13.2)$ & $7.92(26.0)$ & $-0.61(-2.0)$ & $9.1(30)$ & & & $0.135(1.45)$ \\
\hline & 3 & 4 & 1 & $4.24(13.9)$ & $7.92(26.0)$ & $-0.61(-2.0)$ & $9.1(30)$ & & & $0.119(1.28)$ \\
\hline & 4 & 4 & 1 & $3.81(12.5)$ & $7.92(26.0)$ & $-0.61(-2.0)$ & $16.8(55)$ & & & $0.135(1.45)$ \\
\hline & 5 & 4 & 1 & $4.02(13.2)$ & $7.92(26.0)$ & $-0.61(-2.0)$ & $16.8(55)$ & & & $0.118(1.27)$ \\
\hline & 6 & 4 & 1 & $4.24(13.9)$ & $7.92(26.0)$ & $-0.61(-2.0)$ & $16.8(55)$ & & & $0.102(1.10)$ \\
\hline & 7 & 4 & 1 & $4.24(13.9)$ & $7.92(26.0)$ & $-2.13(-7.0)$ & $4.6(15)$ & & & $0.127(1.37)$ \\
\hline & 8 & 4 & 1 & $4.24(13.9)$ & $7.92(26.0)$ & $-1.52(-5.0)$ & $4.6(15)$ & & & $0.122(1.31)$ \\
\hline \multirow[b]{4}{*}{ Plan 2} & 1 & 3 & 2 & $3.81(12.5)$ & $7.62 / 7.92(26.0 / 25.0)$ & $-0.61(-2.0)$ & $16.8(55)$ & & & $0.117(1.26)$ \\
\hline & 2 & 3 & 2 & $3.81(12.5)$ & $7.62 / 7.92(26.0 / 25.0)$ & $-0.61(-2.0)$ & $27.4(90)$ & & & $0.087(0.94)$ \\
\hline & 3 & 3 & 2 & $3.81(12.5)$ & $7.62 / 7.92(26.0 / 25.0)$ & $-0.61(-2.0)$ & $4.6(15)$ & & & $0.140(1.51)$ \\
\hline & 4 & 3 & 2 & $3.81(12.5)$ & $7.62 / 7.92(26.0 / 25.0)$ & $-0.61(-2.0)$ & $9.1(30)$ & & & $0.145(1.56)$ \\
\hline
\end{tabular}




\begin{tabular}{|c|c|c|c|c|c|c|c|c|c|c|}
\hline \multicolumn{11}{|c|}{ Table 10 (Concluded) } \\
\hline Plan & Test & $\begin{array}{l}\text { No. } \\
\text { Steps } \\
\end{array}$ & $\begin{array}{l}\text { No. of } \\
\text { Promen- } \\
\text { ades }\end{array}$ & \begin{tabular}{|l} 
Revetment \\
Crest \\
Elevation \\
m (ft)
\end{tabular} & $\begin{array}{l}\text { Promenade } \\
\text { Width } \\
\text { m (ft) }\end{array}$ & $\begin{array}{l}\text { Toe Berm } \\
\text { Elevation } \\
\text { m (ft) }\end{array}$ & $\begin{array}{l}\text { Toe Berm } \\
\text { Width } \\
\text { m (ft) } \\
\end{array}$ & \begin{tabular}{|l|} 
Distance \\
from \\
Promenade \\
to Offshore \\
Breakwater \\
m (ft) \\
\end{tabular} & $\begin{array}{l}\text { Offshore } \\
\text { Breakwater } \\
\text { Crest } \\
\text { Elevation } \\
\text { m (ft) } \\
\end{array}$ & \begin{tabular}{|l} 
Over- \\
topping \\
Rate \\
$\mathrm{m}^{3} / \mathrm{s} / \mathrm{m}$ (cfs/ft)
\end{tabular} \\
\hline \multirow{6}{*}{\begin{tabular}{|l} 
Plan 2 \\
(cont.) \\
\end{tabular}} & 5 & 3 & 2 & $3.81(12.5)$ & $7.62 / 7.92(26.0 / 25.0)$ & $-0.61(-2.0)$ & $9.1(30)$ & $34(110)$ & $-0.61(-2.0)$ & $0.107(1.15)$ \\
\hline & 6 & 3 & 2 & $3.81(12.5)$ & $7.62 / 7.92(26.0 / 25.0)$ & $0.30(1.0)$ & $9.1(30)$ & $34(110)$ & $-0.61(-2.0)$ & $0.104(1.12)$ \\
\hline & 7 & 3 & 2 & $3.81(12.5)$ & $7.62 / 7.92(26.0 / 25.0)$ & $-0.61(-2.0)$ & $4.6(15)$ & $34(110)$ & $-0.61(-2.0)$ & $0.124(1.33)$ \\
\hline & 8 & 3 & 2 & $3.81(12.5)$ & $7.62 / 7.92(26.0 / 25.0)$ & $0.30(1.0)$ & $4.6(15)$ & $34(110)$ & $-0.61(-2.0)$ & $0.107(1.15)$ \\
\hline & 9 & 3 & 2 & $3.81(12.5)$ & $7.62 / 7.92(26.0 / 25.0)$ & $0.30(1.0)$ & $4.6(15)$ & $34(110)$ & $0.30(1.0)$ & $0.094(1.01)$ \\
\hline & 10 & 3 & 2 & & $7.62 / 7.92(26.0 / 25.0)$ & $0.30(1.0)$ & $4.6(15)$ & $64(210)$ & $0.30(1.0)$ & $0.093(1.00)$ \\
\hline \multirow[b]{6}{*}{ Plan 3} & 1 & 3 & 2 & $4.02(13.2)$ & $7.62 / 7.92(26.0 / 25.0)$ & $0.30(1.0)$ & $4.6(15)$ & $34(110)$ & $0.30(1.0)$ & $0.064(0.69)$ \\
\hline & 2 & 3 & 2 & $4.02(13.2)$ & $7.62 / 7.92(26.0 / 25.0)$ & $0.30(1.0)$ & $4.6(15)$ & $64(210)$ & $0.30(1.0)$ & $0.072(0.77)$ \\
\hline & 3 & 3 & 2 & $4.02(13.2)$ & $7.62 / 7.92(26.0 / 25.0)$ & $0.30(1.0)$ & $4.6(15)$ & & & $0.113(1.22)$ \\
\hline & 4 & 3 & 2 & $4.02(13.2)$ & $7.62 / 7.92(26.0 / 25.0)$ & $1.52(5.0)$ & $4.6(15)$ & & & $0.110(1.18)$ \\
\hline & 5 & 3 & 2 & $4.02(13.2)$ & $7.62 / 7.92(26.0 / 25.0)$ & $-0.61(-2.0)$ & $9.1(30)$ & & & $0.100(1.08)$ \\
\hline & 6 & 3 & 2 & $4.02(13.2)$ & $7.62 / 7.92(26.0 / 25.0)$ & $-0.61(-2.0)$ & $9.1(30)$ & $34(110)$ & $-0.61(-2.0)$ & $0.086(0.93)$ \\
\hline \multirow[b]{2}{*}{ Plan 4} & 1 & 2 & 1 & $4.02(13.2)$ & $9.14(30.0)$ & $-0.61(-2.0)$ & $9.1(30)$ & & & $0.130(1.40)$ \\
\hline & 2 & 2 & 1 & $4.02(13.2)$ & $9.14(30.0)$ & $-0.61(-2.0)$ & $16.8(55)$ & & & $0.108(1.16)$ \\
\hline \multirow[b]{6}{*}{ Plan 5} & 1 & 4 & 1 & $3.81(12.5)$ & $7.92(26.0)$ & $-0.61(-2.0)$ & $9.1(30)$ & & & $0.128(1.38)$ \\
\hline & 2 & 4 & 1 & $4.02(13.2)$ & $7.92(26.0)$ & $-0.61(-2.0)$ & $9.1(30)$ & & & $0.099(1.07)$ \\
\hline & 3 & 4 & 1 & $4.24(13.9)$ & $7.92(26.0)$ & $-0.61(-2.0)$ & $9.1(30)$ & & & $0.081(0.87)$ \\
\hline & 4 & 4 & 1 & $3.81(12.5)$ & $7.92(26.0)$ & $-0.61(-2.0)$ & $16.8(55)$ & & & $0.114(1.23)$ \\
\hline & 5 & 4 & 1 & $4.02(13.2)$ & $7.92(26.0)$ & $-0.61(-2.0)$ & $16.8(55)$ & & & $0.085(0.92)$ \\
\hline & 6 & 4 & 1 & $4.24(13.9)$ & $7.92(26.0)$ & $-0.61(-2.0)$ & $16.8(55)$ & & & $0.067(0.72)$ \\
\hline
\end{tabular}




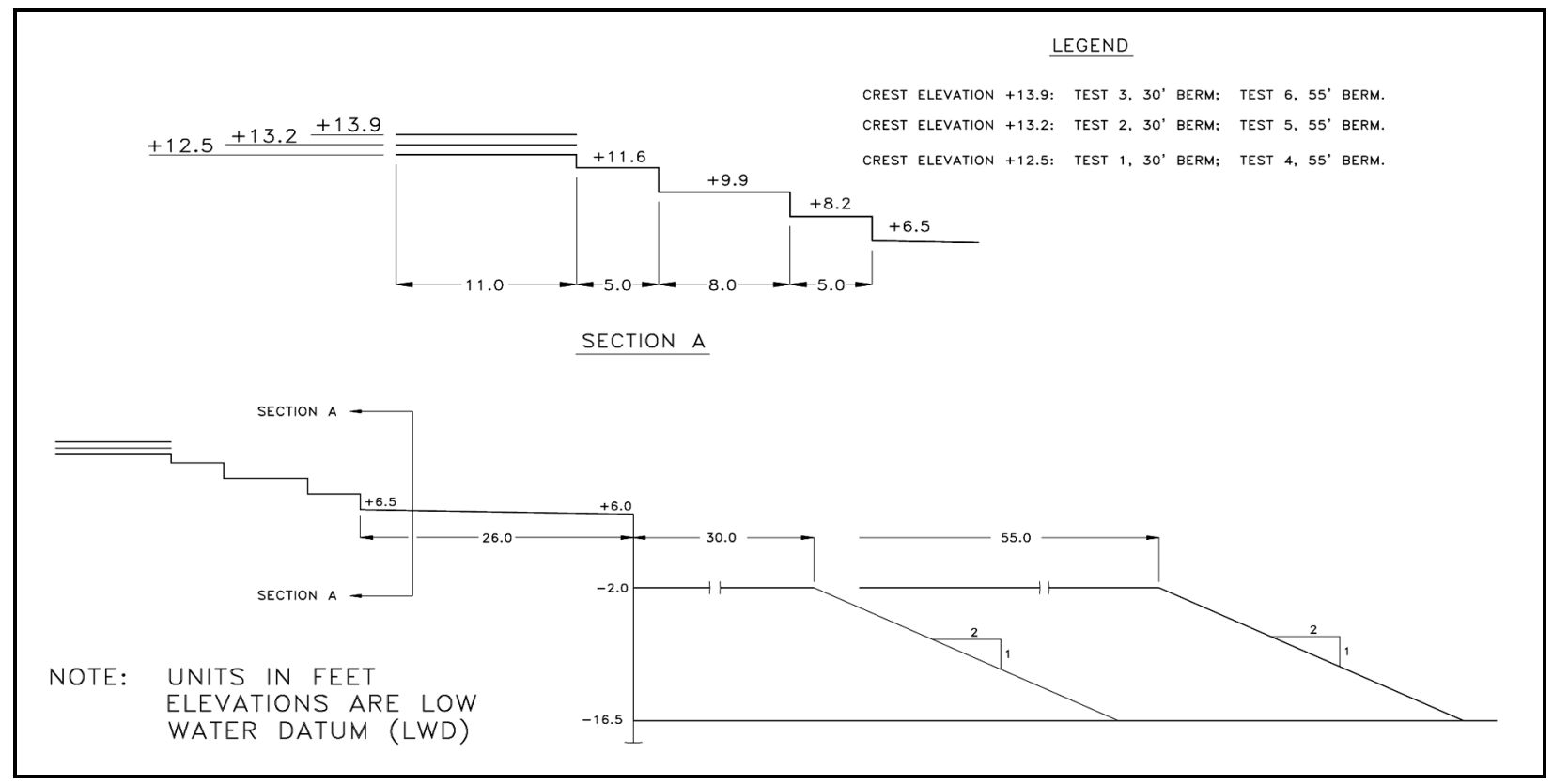

Figure 32. Cross-section of Plan 1 Tests 1 through 6

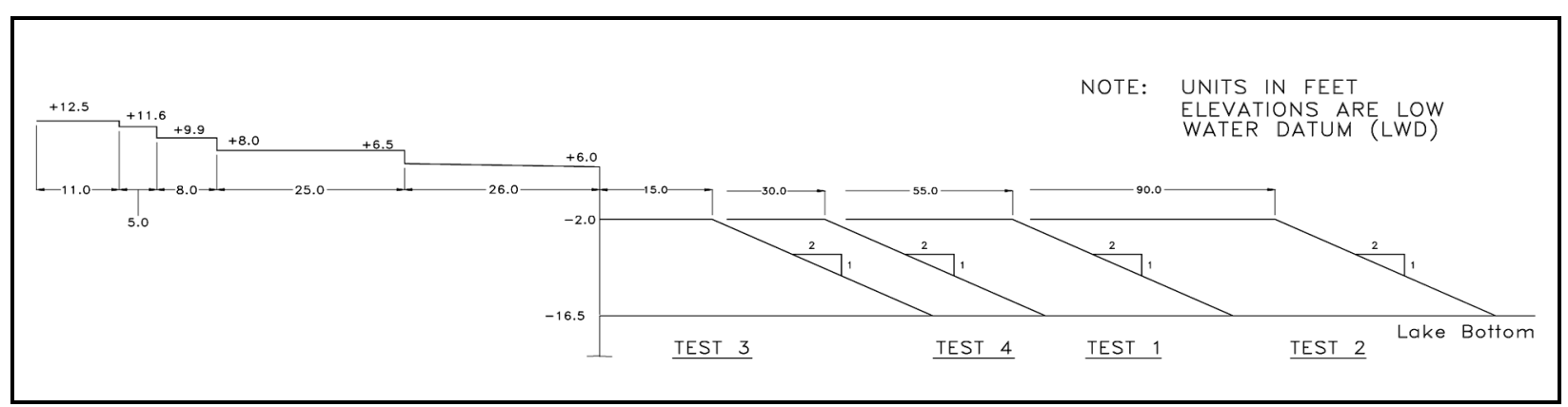

Figure 33. Cross-section of Plan 2 Tests 1 through 4

Experiments included a 9.14-m-wide (30.0-ft) toe berm at elevation $-0.61 \mathrm{~m}$ $(-2.0 \mathrm{ft})$ with breakwater crest elevation at $-0.61-\mathrm{m}(-2.0 \mathrm{ft})$, and a $9.14-\mathrm{m}$-wide $(30.0-\mathrm{ft})$ toe berm at elevation $+0.30 \mathrm{~m}(+1.0 \mathrm{ft})$ with breakwater crest elevation of $-0.61 \mathrm{~m}(-2.0 \mathrm{ft})$. Experiments with a $4.57-\mathrm{m}$-wide $(15.0-\mathrm{ft})$ toe berm included toe berm and breakwater both with crest elevation of $-0.61 \mathrm{~m}(-2.0 \mathrm{ft})$, toe berm crest elevation of $+0.30 \mathrm{~m}(+1.0 \mathrm{ft})$ and breakwater crest elevation of $-0.61 \mathrm{~m}(-2.0 \mathrm{ft})$, and both toe berm and breakwater at crest elevation of $+0.30 \mathrm{~m}$ $(+1.0 \mathrm{ft})$. Tests 5 through 10 of Plan 2 are illustrated in Figures 34 through 39, respectively. 


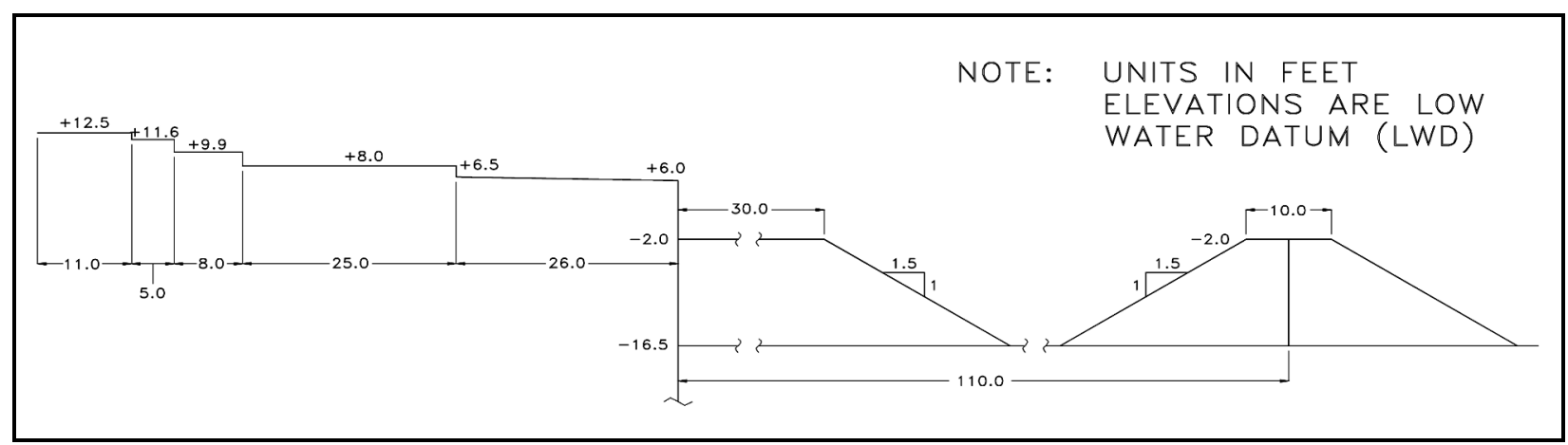

Figure 34. Cross-section of Plan 2 Test 5

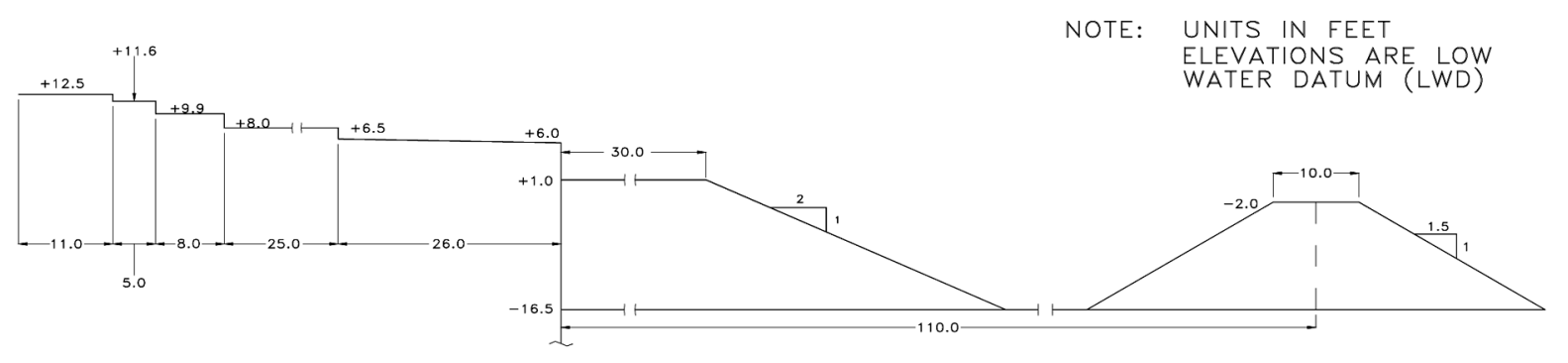

Figure 35. Cross-section of Plan 2 Test 6

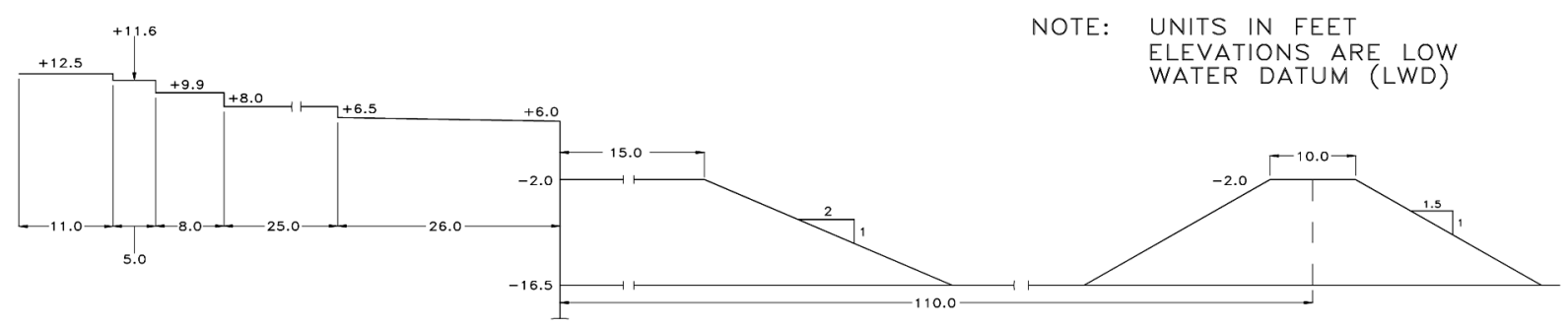

Figure 36. Cross-section of Plan 2 Test 7

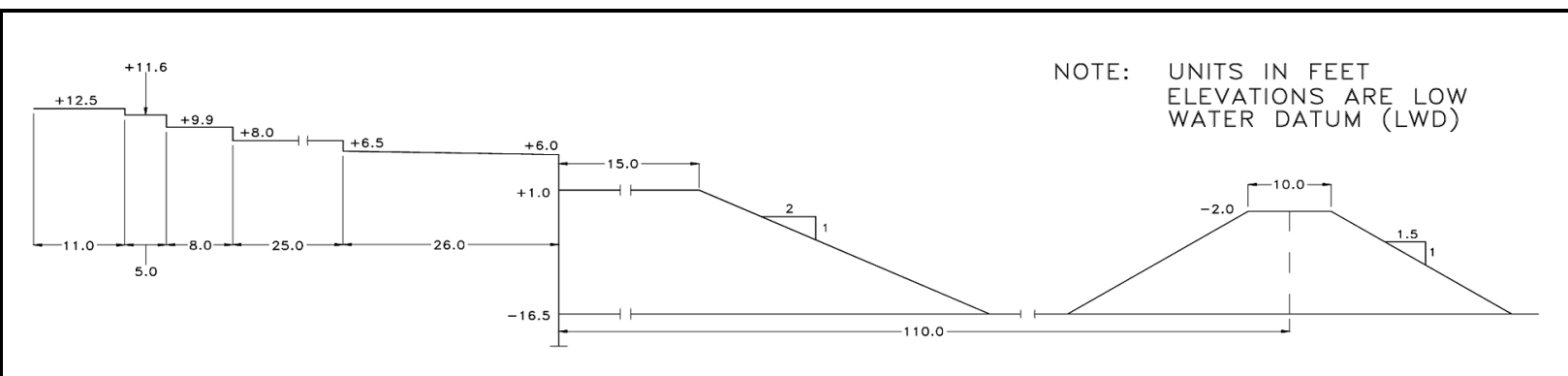

Figure 37. Cross-section of Plan 2 Test 8 


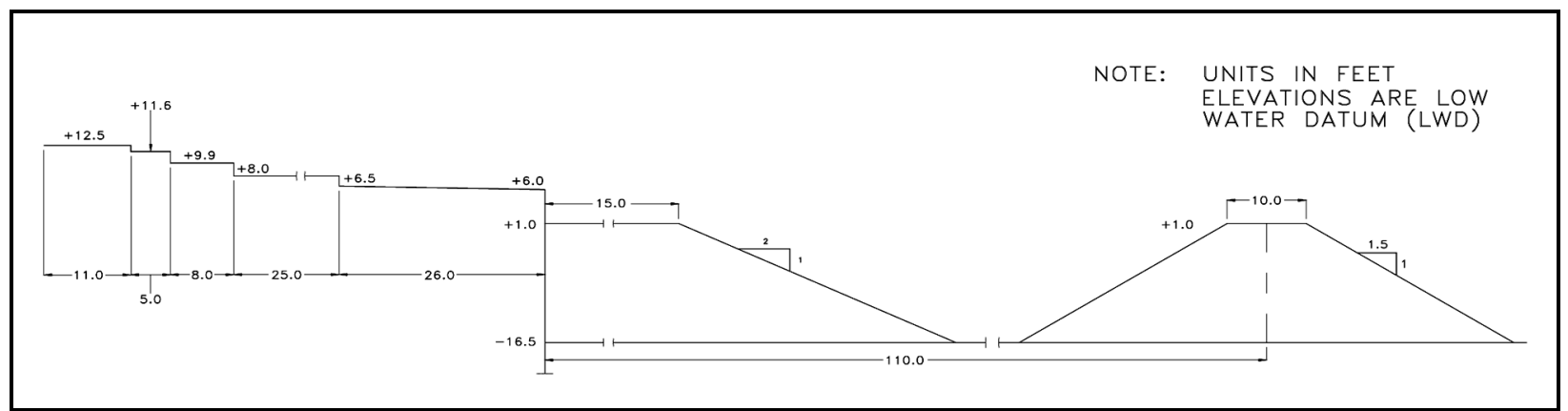

Figure 38. Cross-section of Plan 2 Test 9

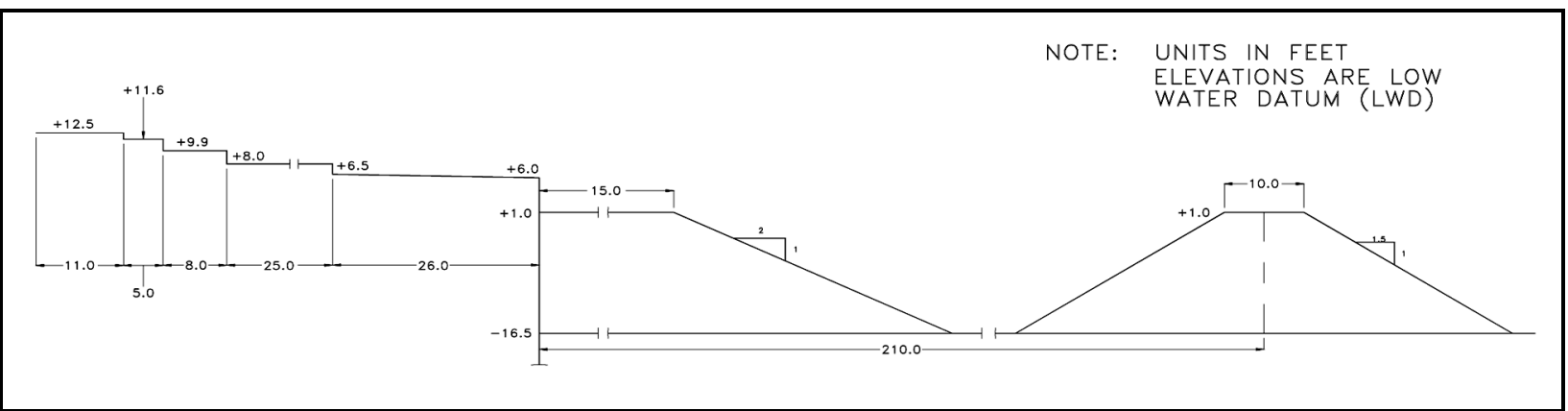

Figure 39. Cross-section of Plan 2 Test 10

Plan 3 was identical to Plan 2 but added a cap to the top step resulting in a crest elevation of $+4.02 \mathrm{~m}(+13.2 \mathrm{ft})$. Experiments were conducted with a 4.57m-wide $(15.0-\mathrm{ft})$ toe berm at crest elevation of $+0.30 \mathrm{~m}(+1.0 \mathrm{ft})$ and the offshore breakwater with crest elevation of $+0.30 \mathrm{~m}(1.0 \mathrm{ft})$, and again with the offshore breakwater moved an additional $30.5 \mathrm{~m}(100 \mathrm{ft})$ offshore to a total distance of $64.0 \mathrm{~m}(210 \mathrm{ft})$ from edge of promenade. Additional experiments removed the offshore breakwater and included a $4.57-\mathrm{m}$-wide $(15.0-\mathrm{ft})$ toe berm at crest elevation $+0.30 \mathrm{~m}(+1.0 \mathrm{ft})$ and $+1.52 \mathrm{~m}(+5.0 \mathrm{ft})$, and a 9.14-m-wide $(30.0-\mathrm{ft})$ toe berm at crest elevation of $-0.61 \mathrm{~m}(-2.0 \mathrm{ft})$. One additional experiment was conducted with the 9.14-m-wide (30.0-ft) toe berm at crest elevation of $-0.61 \mathrm{~m}$ $(-2.0 \mathrm{ft})$ and the offshore breakwater re-installed $64.0 \mathrm{~m}(210 \mathrm{ft})$ offshore with crest elevation of $-0.61 \mathrm{~m}(-2.0 \mathrm{ft})$. Tests 1 through 6 of Plan 3 are illustrated in Figures 40 through 45, respectively.

Plan 4 consisted of Plan A from Phase I with an extra layer on the top step to raise the crest elevation to $+4.02 \mathrm{~m}(+13.2 \mathrm{ft})$. No offshore breakwater was employed. Experiments were conducted with a 9.14-m-wide $(30.0-\mathrm{ft})$ and a 16.76-m-wide (55.0-ft) toe berm, both with crest elevation of $-0.61 \mathrm{~m}(-2.0 \mathrm{ft})$. Plan 4 is illustrated in Figure 46. 


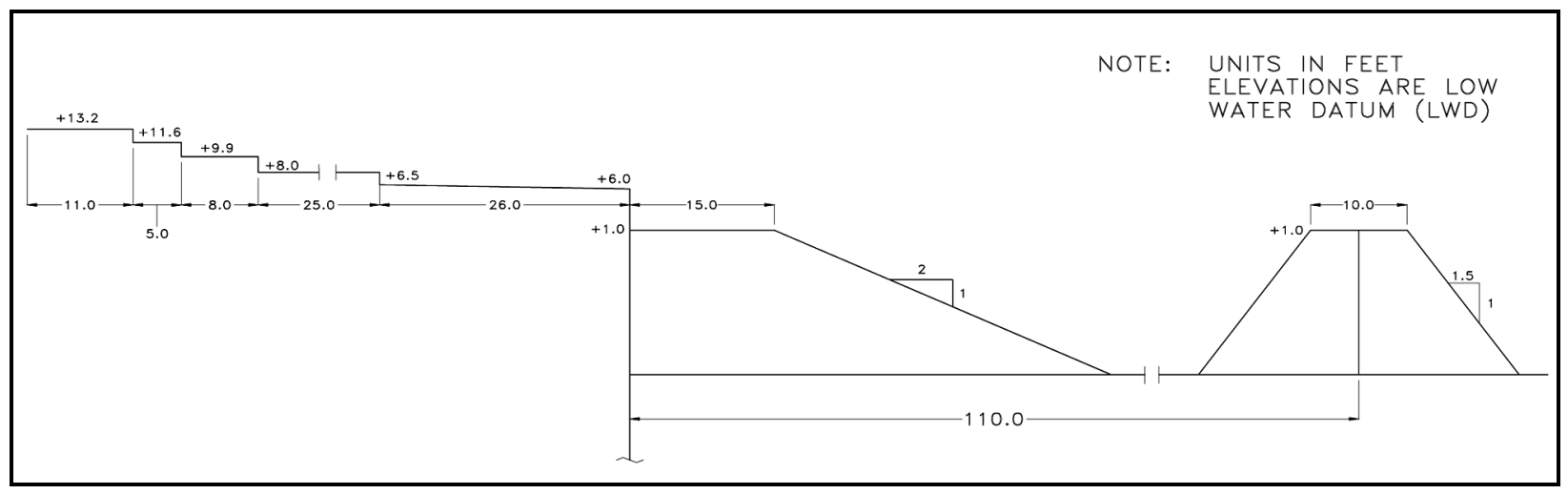

Figure 40. Cross-section of Plan 3 Test 1

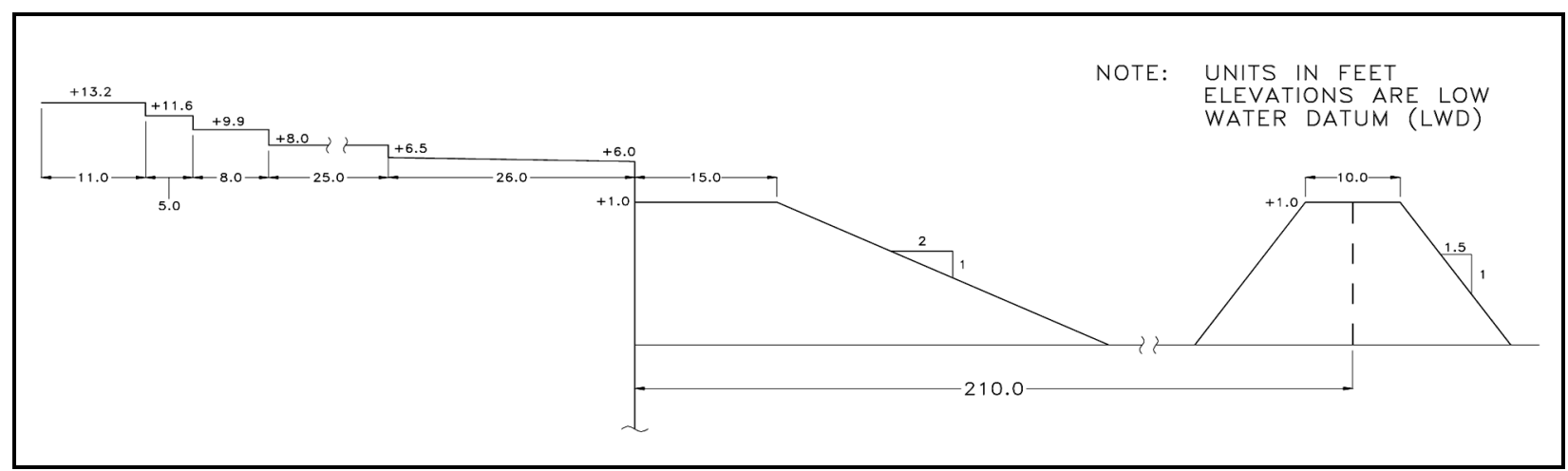

Figure 41. Cross-section of Plan 3 Test 2

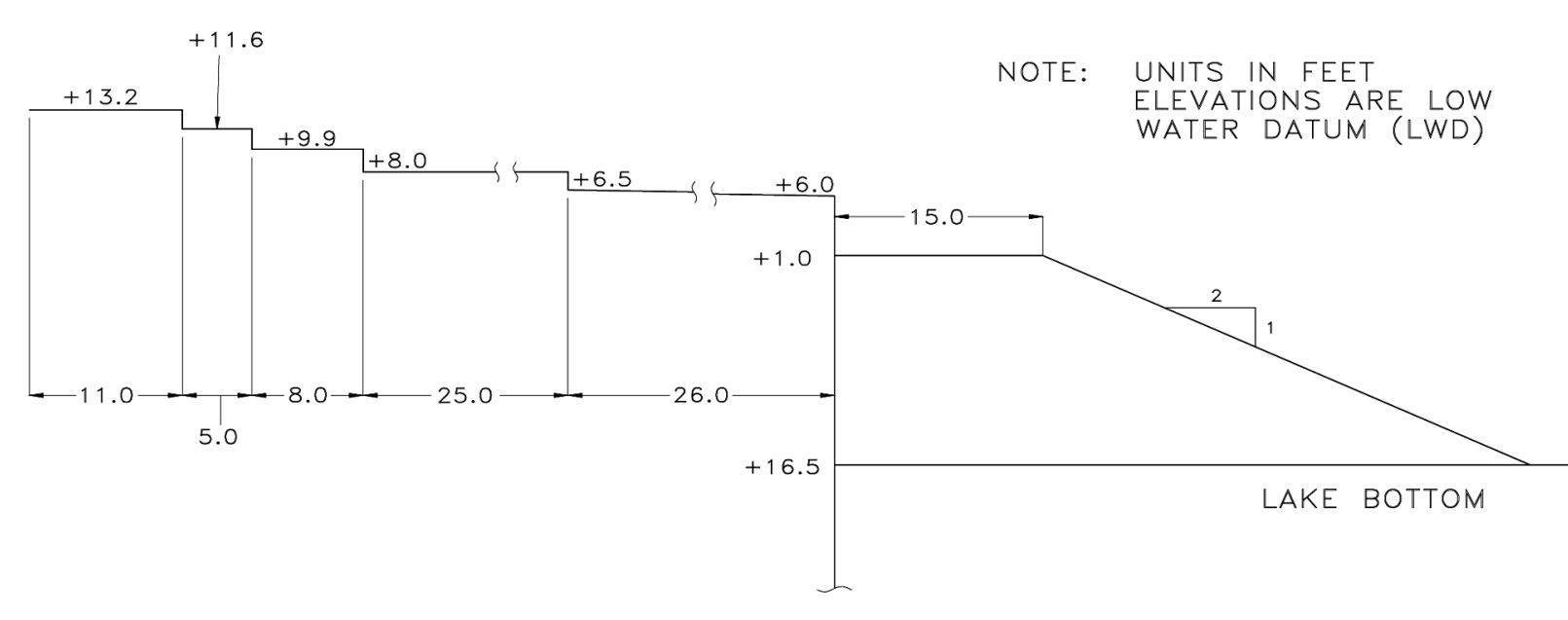

Figure 42. Cross-section of Plan 3 Test 3 


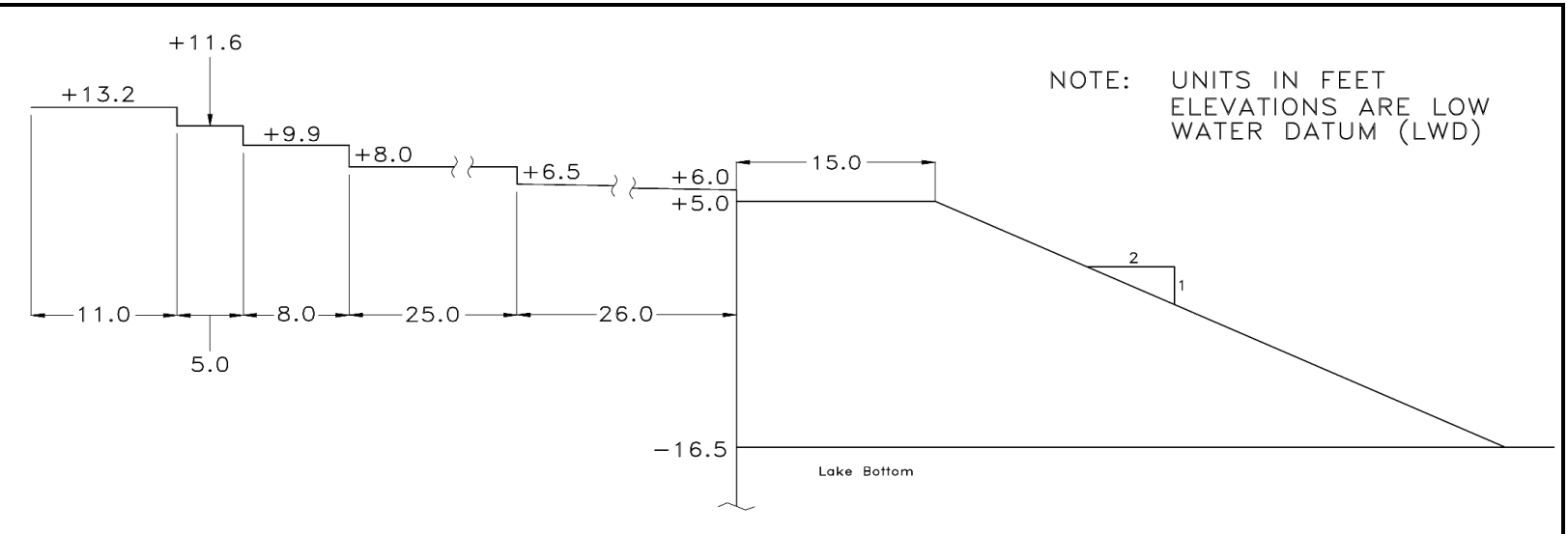

Figure 43. Cross-section of Plan 3 Test 4

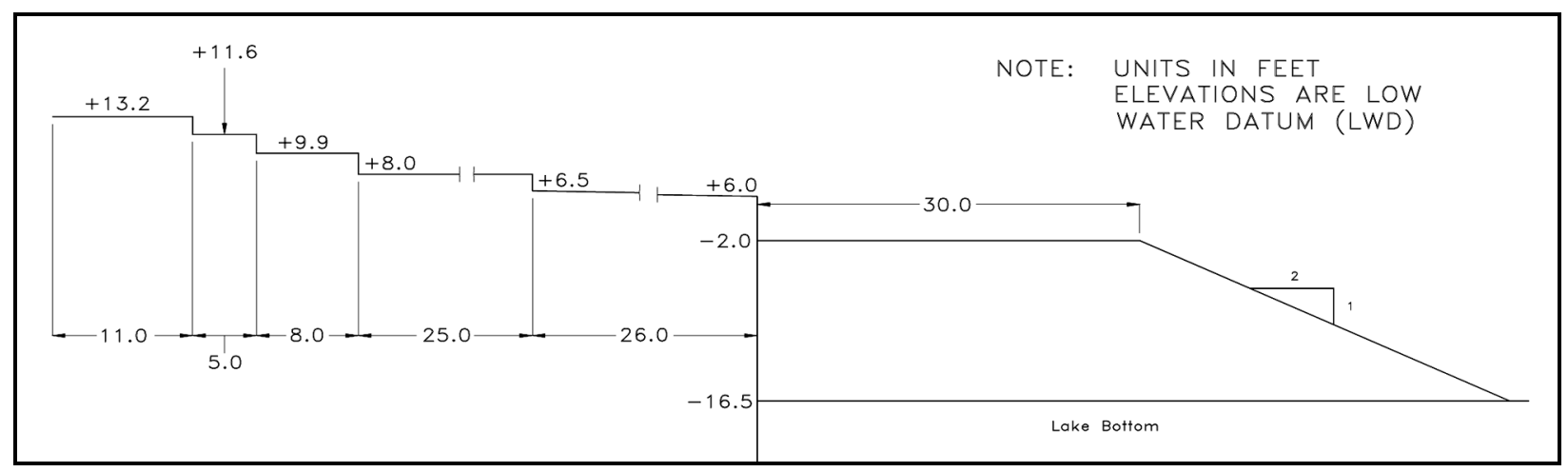

Figure 44. Cross-section of Plan 3 Test 5

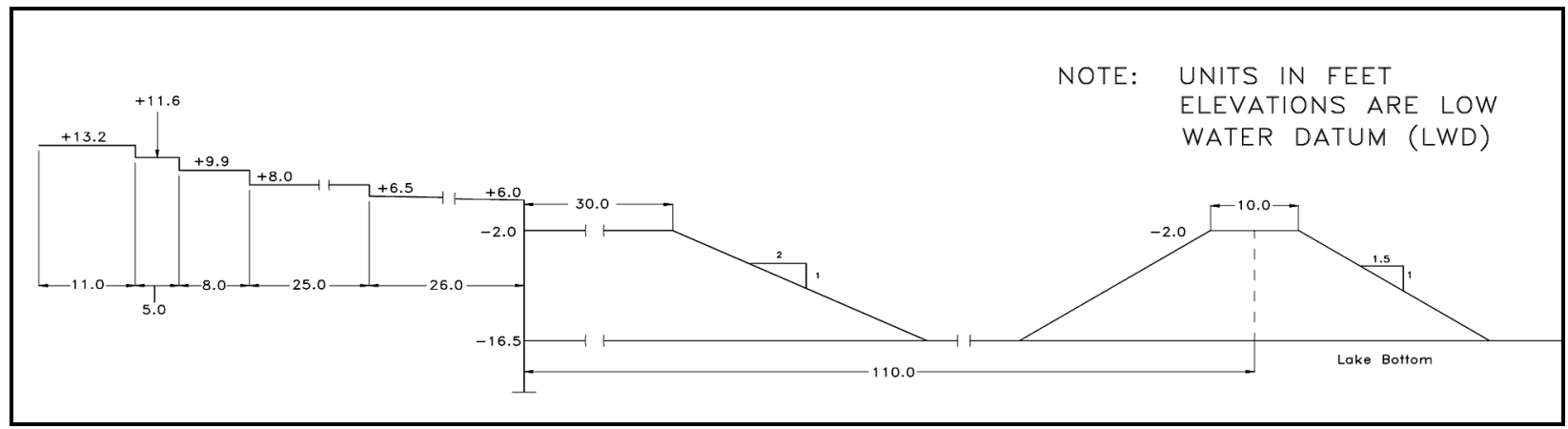

Figure 45. Cross-section of Plan 3 Test 6 


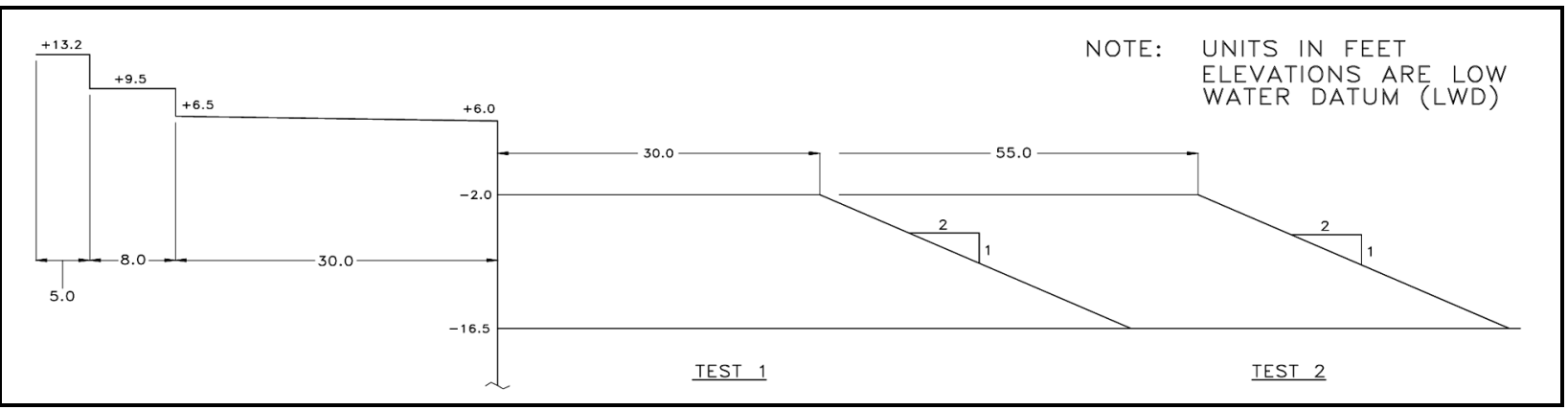

Figure 46. Cross-section of Plan 4 Tests 1 and 2

Plan 5 was similar to Plan 1 but increased the widths of the steps to $3.96 \mathrm{~m}$ $(13.0 \mathrm{ft})$ for each of the lower two steps and 3.66-m (12.0-ft) width for the next higher step. The $3.35-\mathrm{m}(11.0-\mathrm{ft})$ width on the crest was retained. Plan 5 is illustrated in Figure 47. Similar to Plan 1, overtopping rates were determined for crest elevations of $+3.81,+4.02,+4.24 \mathrm{~m}(+12.5,+13.2$, and $+13.9 \mathrm{ft})$, with both 9.14-m-wide (30.0-ft) and 16.76-m-wide (55.0-ft) toe berms at crest elevation of $-0.61 \mathrm{~m}(-2.0 \mathrm{ft})$.

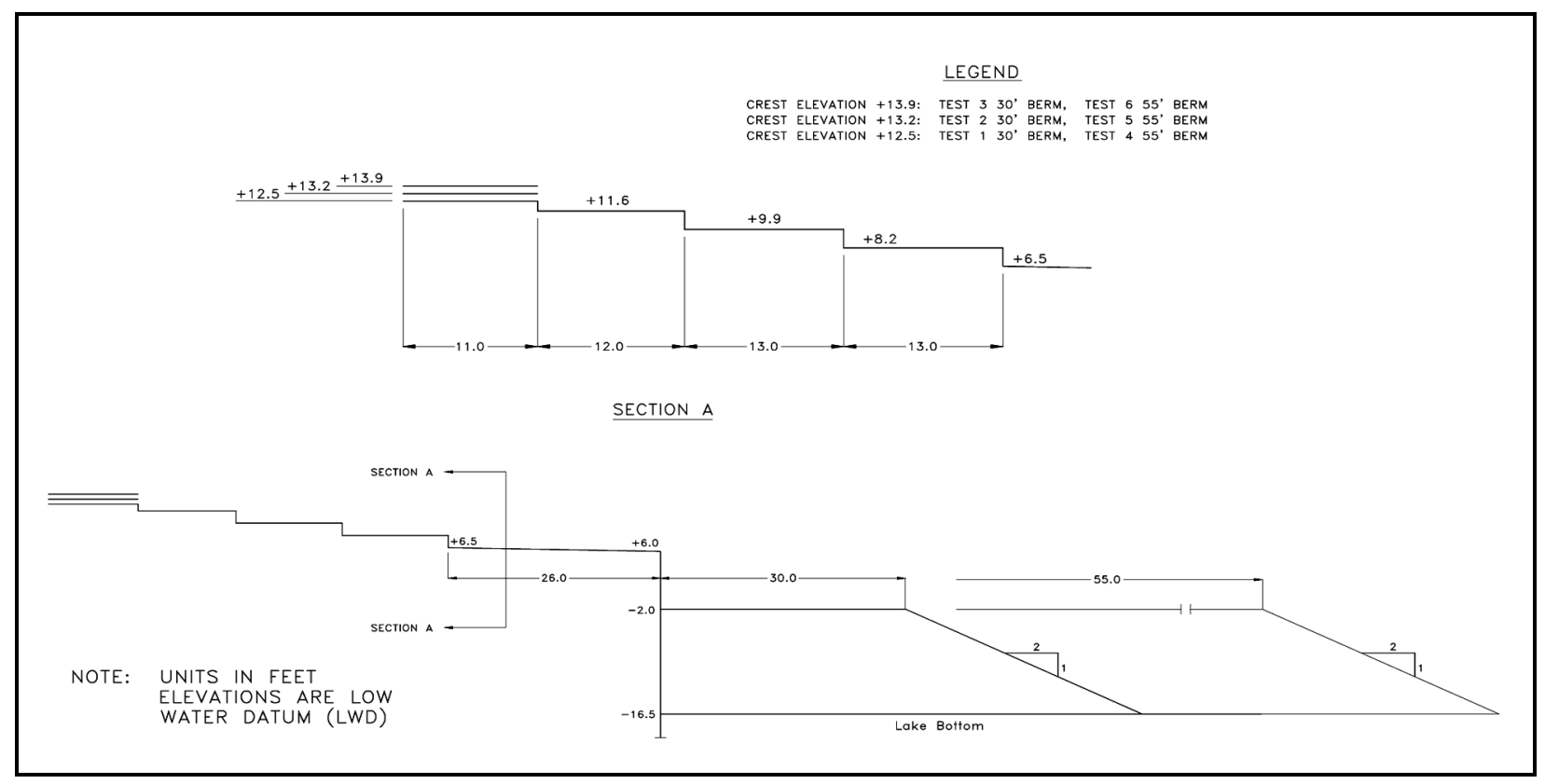

Figure 47. Cross-sections of Plan 5 Tests 1 through 6

At the request of LRC, Plan 1 was re-installed in the flume with a 4.6-m-wide $(15-\mathrm{ft})$ toe berm at crest elevations of $-2.1 \mathrm{~m}(-7 \mathrm{ft})$ and $-1.5 \mathrm{~m}(-5 \mathrm{ft})$. Crest elevation was $+4.24 \mathrm{~m}(+13.9 \mathrm{ft})$, and no offshore breakwater was installed. Figure 48 illustrates these variations to Plan 1.

Overtopping rates for all experiments in Phase III are given in Table 10. 


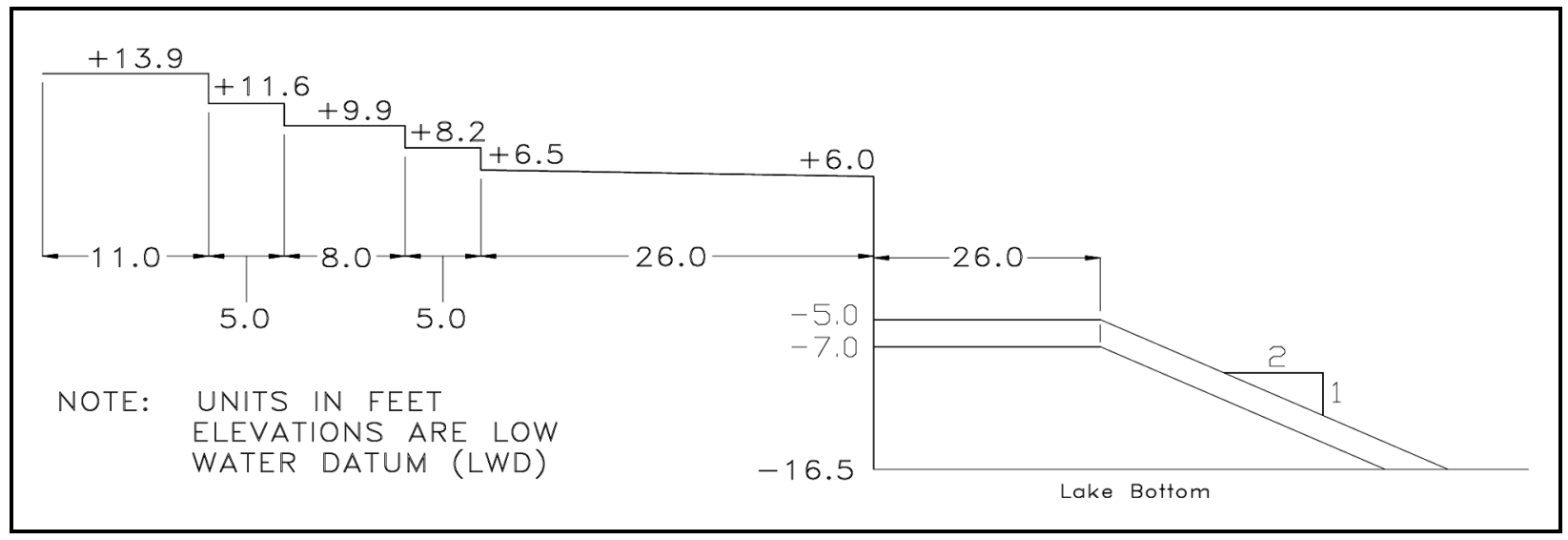

Figure 48. Cross-sections of Plan 1 Tests 7 (toe berm at -5.0 ) and 8 (toe berm at -7.0 )

\section{Toe stability}

The bathymetry in the vicinity of Diversey to Fullerton was similar to the deep-water toe section of Reach $4,26^{\text {th }}$ St. the $33^{\text {rd }}$ St., that had been modeled in Phases I and II of this study. Scour protection for the Diversey to Fullerton revetment models therefore was similar the deep-water toe protection employed in Phases I and II. The toe of the revetment was located at a depth of $-5.03 \mathrm{~m}$ ($16.5 \mathrm{ft}$ ). The toe berms were constructed with 2.7- to 8.2-tonne (3- to 9-ton) stone to the elevation and widths indicated in Table 10 for the various revetment configurations examined, then sloped at 1:2 to the false bottom of the wave flume. The false bottom under the toe berm was roughened with sand to provide resistance to sliding, but no bedding layer was used in the Diversey to Fullerton experiments. Stability of the toe berm was observed during overtopping experiments, no additional experiments were conducted for stability.

No movement of toe stone was observed in the experiments with the exception of Plan 1 Test 8 . Plan 1 Test 8 lowered the crest of the toe berm to $1.52 \mathrm{~m}(-5.0 \mathrm{ft})$. Rocking of stones on the crest of the toe berm was observed, but no stones were displaced.

Where employed in the experiments, the offshore breakwater was also constructed of 2.7- to 8.2-tonne (3- to 9-ton) stone with no bedding layer. The false bottom beneath the offshore breakwater was not roughened. No stone movement was observed on the offshore breakwater.

\section{Phase IV: $57^{\text {th }}$ St.}

The bathymetry near $57^{\text {th }}$ St. differs from the reaches in Phases I through III in that the water is quite shallow and incident waves will be significantly refracted before reaching the project site. The site is partially sheltered, and reduced wave heights are expected at the structure. The $57^{\text {th }}$ St. area is shown in Figure 49. 


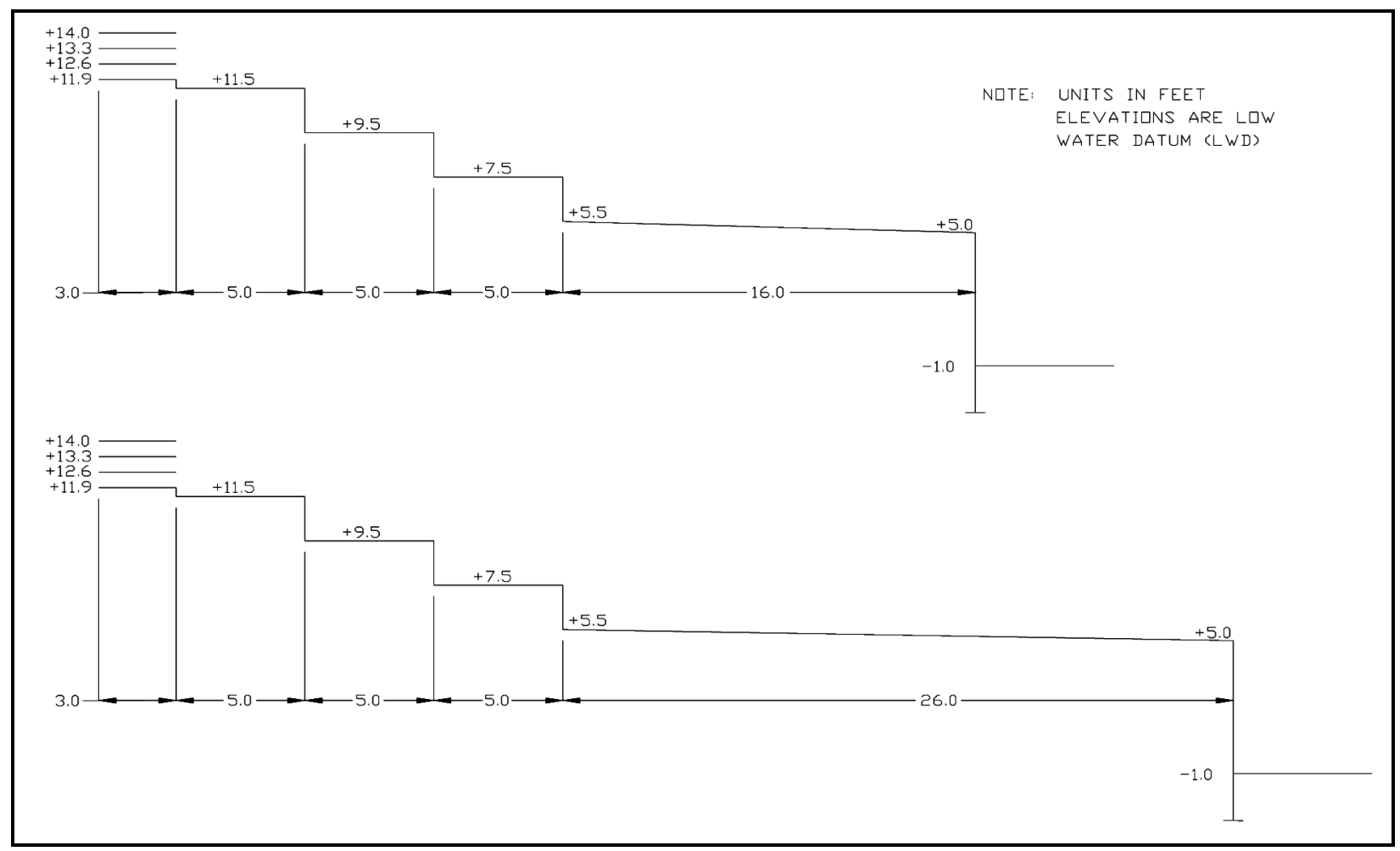

Figure 49. Cross-sections of 57 th St. revetments

Prototype bathymetry is shown in Table 11 (received from STS Consultants, Ltd., Vernon Hills, Illinois). The numbers indicate a depth of $-0.30 \mathrm{~m}(-1.0 \mathrm{ft})$ at the structure toe, then an approximately 1:50 slope to a depth of $-2.44 \mathrm{~m}(-8.0 \mathrm{ft})$, followed by an approximately 1:200 slope to a depth of $-5.49 \mathrm{~m}(-18.0 \mathrm{ft})$.

Prototype bathymetry was approximated in the wave flume by lowering the water level in the flume such that the false bottom was at $-3.35 \mathrm{~m}(-11.0 \mathrm{ft})$, setting the depth at the structure toe at $-0.30 \mathrm{~m}(-1.0 \mathrm{ft})$, and adding a 1:50 slope from the revetment toe to the false bottom. Depth at the wave board was $11.37 \mathrm{~m}(37.3 \mathrm{ft})$ for experiments with SWL of $+1.80 \mathrm{~m}(+5.9 \mathrm{ft})$.

\begin{tabular}{|c|c|}
\hline \multicolumn{2}{|c|}{$\begin{array}{l}\text { Table } 11 \\
\text { Bathymetry in Vicinity of } 57^{\text {th }} \mathrm{St} \text {. }\end{array}$} \\
\hline Distance from Promenade, $\mathrm{m}$ (ft) & Depth, m (ft) \\
\hline $0.0(0.0)$ & $-0.30(-1.0)$ \\
\hline $13.7(45)$ & $-0.61(-2.0)$ \\
\hline $24.4(80)$ & $-0.91(-3.0)$ \\
\hline $39.6(130)$ & $-1.22(-4.0)$ \\
\hline $54.9(180)$ & $-1.52(-5.0)$ \\
\hline $70.1(230)$ & $-1.83(-6.0)$ \\
\hline $91.4(300)$ & $-2.13(-7.0)$ \\
\hline $115.8(380)$ & $-2.44(-8.0)$ \\
\hline $387.1(1,270)$ & $-3.66(-12.0)$ \\
\hline $771.1(2,530)$ & $-5.49(-18.0)$ \\
\hline
\end{tabular}


The model included a single promenade and four steps leading to the crest. Width of the steps was $1.52 \mathrm{~m}(5.0 \mathrm{ft})$ for the first three steps, then a $0.91-\mathrm{m}$-wide (3.0 ft) top step. By adding layers over the top step, crest elevations of +3.62 , $+3.84,+4.05$, and $+4.27 \mathrm{~m}(+11.9,+12.6,+13.3$, and $+14.0 \mathrm{ft})$ were obtained. Experiments were conducted with each of the four crest elevations and promenade widths of 4.88 and $7.92 \mathrm{~m}(16.0$ and $26.0 \mathrm{ft})$. Each crest elevation/promenade width combination was tested with incident significant wave heights of $2.13,2.74$, and $3.35 \mathrm{~m}(7.0,9.0$, and $11.0 \mathrm{ft})$, all at a peak period of $12.4 \mathrm{~s}$. Toe berm was 3.0 -m-wide $(10.0-\mathrm{ft})$ at elevation $+0.9 \mathrm{~m}(+3 \mathrm{ft})$. The $57^{\text {th }}$ St. revetments are illustrated in Figure 49, overtopping rates for each of the $57^{\text {th }}$ St. experiments are given in Table 12.

\begin{tabular}{|c|c|c|c|c|}
\hline \multicolumn{5}{|c|}{$\begin{array}{l}\text { Table } 12 \\
\text { Overtopping Rates (Prototype) for } 57^{\text {th }} \text { St. Revetment }\end{array}$} \\
\hline \multirow{3}{*}{\begin{tabular}{|l} 
Width of \\
Promenade \\
m (ft) \\
\end{tabular}} & \multirow{3}{*}{$\begin{array}{l}\text { Crest Elevation } \\
\mathrm{m}(\mathrm{ft})\end{array}$} & \multicolumn{3}{|c|}{ Wave Height, $\mathrm{Hs}$} \\
\hline & & $2.1 \mathrm{~m}(7 \mathrm{ft})$ & $2.7 \mathrm{~m} \mathrm{(9ft)}$ & $3.4 \mathrm{~m}(11 \mathrm{ft})$ \\
\hline & & \multicolumn{3}{|c|}{ Overtopping Rate $\mathrm{m}^{3} / \mathrm{s} / \mathrm{m}$ (cfs/ft) } \\
\hline \multirow[b]{4}{*}{$7.9(26)$} & $3.63(11.9)$ & $0.035(0.38)$ & $0.052(0.56)$ & $0.046(0.50)$ \\
\hline & $3.84(12.6)$ & $0.021(0.23)$ & $0.033(0.36)$ & $0.039(0.42)$ \\
\hline & $4.08(13.3)$ & $0.020(0.22)$ & $0.029(0.31)$ & $0.029(0.31)$ \\
\hline & $4.27(14.0)$ & $0.016(0.17)$ & $0.023(0.25)$ & $0.021(0.23)$ \\
\hline \multirow[b]{4}{*}{$4.9(16)$} & $3.63(11.9)$ & $0.050(0.54)$ & $0.056(0.60)$ & $0.068(0.73)$ \\
\hline & $3.84(12.6)$ & $0.038(0.41)$ & $0.049(0.53)$ & $0.045(0.48)$ \\
\hline & $4.08(13.3)$ & $0.030(0.32)$ & $0.036(0.39)$ & $0.041(0.44)$ \\
\hline & $4.27(14.0)$ & $0.025(0.27)$ & $0.034(0.37)$ & $0.033(0.35)$ \\
\hline
\end{tabular}

\section{Regression Overtopping Equation}

Data from the storm hydrographs of the LPP (Phase II) and the $57^{\text {th }}$ St. overtopping experiments were combined to obtain a regression equation that would predict overtopping rates for a range of revetment configurations, water levels, and incident wave heights and periods. The general form of the equation was

$$
Q=C_{0} \exp \left(C_{1} R_{1}+C_{2} R_{2}+C_{3} D_{1}\right)
$$

where $Q$ is dimensional overtopping defined as

$$
Q=\frac{75 q+1}{\sqrt{g H_{i}^{3}}}
$$

where $q$ is measured overtopping rate in wave flume in $\mathrm{cfs} / \mathrm{ft}, g$ is acceleration of gravity in $\mathrm{ft} / \mathrm{s}^{2}$, and $H_{i}$ is incident significant wave height at structure toe in 
feet. English units must be used for the overtopping rate due to the weight function, $75 q+1 . R_{1}$ and $R_{2}$ are dimensionless freeboards defined by

$$
R_{1}=\frac{h_{\text {prom }}-S W L}{\sqrt[3]{H_{o}^{2} L_{o}}}
$$

where $h_{\text {prom }}$ is elevation at lakeward end of promenade, $H_{o}$ is incident wave height at wave generator, and $L_{o}$ is deepwater wave length determined by wave period of peak energy density at the wave board, and

$$
R_{2}=\frac{h_{\text {crest }}-S W L}{\sqrt[3]{H_{o}^{2} L_{o}}}
$$

where $h_{\text {crest }}$ is elevation at crest of revement, and $D_{l}$ is dimensionless depth defined as

$$
D_{1}=\frac{S W L-h_{t o e}}{L_{i}}
$$

where $h_{\text {toe }}$ is elevation at toe of revetment (below toe berm) and $L_{i}$ is wavelength determined from wave period of peak energy density and depth at revetment toe (bottom of toe berm directly in front of promenade), and $C_{0}, C_{1}$, $C_{2}$, and $C_{3}$ are regression coefficients.

Wave height at structure toe, $H_{i}$, was estimated by the method of Goda (1988).

$$
H_{s}= \begin{cases}K_{s} H_{o}^{\prime} & : d_{t o e} / L_{o} \geq 0.2 \\ \min \left\{\left(\beta_{0} H_{o}^{\prime}+\beta_{1} h_{t o e}\right), \beta_{\text {max }} H_{o}^{\prime}, K_{s} H_{o}^{\prime}\right\}: d_{t o e} / L_{o}<0.2\end{cases}
$$

where $\mathrm{K}_{\mathrm{s}}$ is the shoaling coefficient defined as

$$
K_{s}=\frac{1}{\sqrt{\left[1+\frac{4 \pi d_{t o e} / L_{i}}{\sinh \left(4 \pi d_{t o e} / L_{i}\right)}\right] \tanh \left(2 \pi d_{t o e} / L_{i}\right)}}
$$

where $d_{\text {toe }}$ is depth at structure toe $\left(S W L-h_{\text {toe }}\right)$ and the beta coefficients are defined as

$$
\begin{aligned}
& \beta_{0}=0.028\left(H_{o}^{\prime} / L_{o}\right)^{-0.38} \exp \left(20 \tan ^{1.5} \theta\right) \\
& \beta_{1}=0.52 \exp (4.2 \tan \theta)
\end{aligned}
$$




$$
\beta_{\max }=\max \left\{0.92,0.32\left(H_{o}^{\prime} / L_{o}\right)^{-0.29} \exp (2.4 \tan \theta\}\right.
$$

where $\theta$ is the $1: 50$ slope.

Equation 5 was linearized by taking the natural logarithm of each side as

$$
\ln (Q)=\ln \left(C_{0}\right)+C_{1} R_{1}+C_{2} R_{2}+C_{3} D_{1}
$$

and solving for the regression coefficients with a standard linear regression program. Results of the analysis gave an $R^{2}$ correlation of 0.91 . Values for

\begin{tabular}{|c|c|c|c|c|}
\hline \multicolumn{5}{|c|}{$\begin{array}{l}\text { Table } 13 \\
\text { Regression Coefficients with Standard Error and } 95 \text { Percent } \\
\text { Confidence Limits }\end{array}$} \\
\hline Coefficient & Value & Standard Error & Lower $95 \%$ & Upper $95 \%$ \\
\hline$\overline{l n}\left(C_{0}\right)$ & 1.121 & 0.184 & 0.756 & 1.487 \\
\hline$c_{1}$ & -7.743 & 1.575 & -10.870 & -4.617 \\
\hline$C_{2}$ & -10.501 & 0.747 & -11.984 & -9.018 \\
\hline$C_{3}$ & -14.222 & 2.571 & -19.325 & -9.120 \\
\hline
\end{tabular}
coefficients, standard errors, and 95\% confidence bounds are given in Table 13 .

Figure 50 illustrates overtopping rates predicted by Equation 18 using coefficients in Table 13 versus measured overtopping rates. Ranges of parameters used in the regression equation are listed in Table 14.

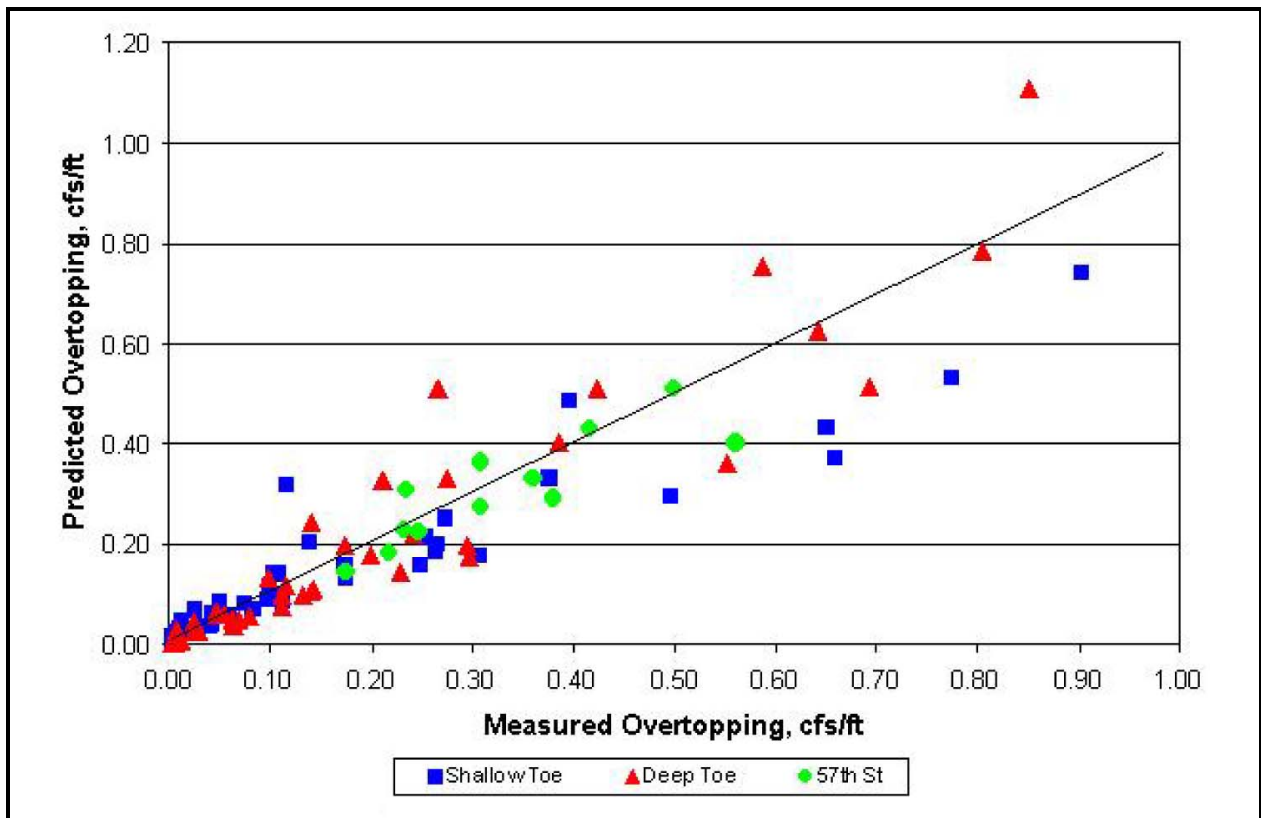

Figure 50. Predicted vs measured overtopping rates 


\begin{tabular}{|c|c|c|}
\hline 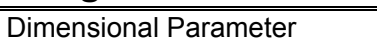 & Minimum & Maximum \\
\hline $\begin{array}{c}\left(h_{\text {crest }}-\mathrm{SWL}\right) \mathrm{m}(\mathrm{ft}) \\
\end{array}$ & $1.83(6.0)$ & $3.51(11.5)$ \\
\hline$H_{\mathrm{i}} \mathrm{m}(\mathrm{ft})$ & $1.57(5.2)$ & $4.55(14.9)$ \\
\hline$\left(h_{\text {prom }}-\mathrm{SWL}\right) \mathrm{m}(\mathrm{ft})$ & $-0.27(-0.9)$ & $0.76(2.5)$ \\
\hline$H_{0} \mathrm{~m}(\mathrm{ft})$ & $1.71(5.6)$ & $5.61(18.4)$ \\
\hline$L_{0} \mathrm{~m}(\mathrm{ft})$ & $126.4(415)$ & $239.9(787)$ \\
\hline$\left(\mathrm{SWL}-h_{\text {toe }}\right) \mathrm{m}(\mathrm{ft})$ & $2.10(6.9)$ & $6.83(22.4)$ \\
\hline$T_{p} \mathrm{~S}$ & 9.0 & 12.4 \\
\hline Non-dimensional Parameter & Minimum & Maximum \\
\hline $\bar{L}_{1}$ & 0.038 & 0.098 \\
\hline$R_{1}$ & -0.027 & 0.098 \\
\hline$R_{2}$ & 0.131 & 0.453 \\
\hline
\end{tabular}

\section{Limitations of Physical Model Studies}

Experiments for this study were conducted in a glass-walled two-dimensional wave flume with a false bottom constructed of plywood. Experience at CHL has shown that friction losses with glass-walled wave flumes are minimal, and that the plywood false bottom is a reasonable reproduction of bottom losses in the prototype. The false bottom does not accurately reproduce the bathymetry lakeward of the Chicago shoreline but is a reasonable representation of the bathymetry to the extent of the flat section of the false bottom. The 1:20 slope from the false bottom to the flume bottom in the model does not occur in the prototype and may alter the incident wave trains in the physical model. Waves breaking on the 1:20 slope may be more severe in the model than in the prototype due to the flatter slopes in the prototype. In the physical model, wave energy reflected off the model revetment remains in the wave flume and is re-reflected off the wave board with the potential of causing an increase in incident wave energy. However, the severe wave conditions used in these experiments and the shallow water near the shoreline produced a saturated wave environment whereby additional wave energy is lost through wave breaking. The wave energy reaching the model shoreline is therefore considered to accurately reproduce prototype conditions at the prototype shoreline.

Onshore winds during storm events have been shown to increase overtopping due to splash and spray, but have little effect on overtopping by the wave itself (Ward $1998^{1}$ ). Total quantity of overtopping contributed by splash and spray is negligible compared to the overtopping of the waves in the present study. Onshore winds may carry splash and spray shoreward a considerable distance and may pose problems with icing of nearshore roads, but do not significantly contribute to overtopping rates in the present study.

\footnotetext{
${ }^{1}$ Ward, Donald L. 1998. "Wind effects on runup and overtopping of coastal structures," PhD dissertation, Texas A\&M University, College Station, Texas.
} 


\section{Conclusions}

Experiments were conducted to determine overtopping rates for a range of design storm conditions for several design configurations that retained the basic seawall and stepped revetment configuration of the existing shoreline.

Configurations that reduced overtopping rates to reasonably low levels included high crest elevations, a large parapet on the promenade, or an offshore breakwater. For reasons of aesthetics, safety, etc., none of these options were acceptable to the local sponsors.

Design configurations that met the requirements delineated by the local sponsors produced higher overtopping rates that will result in inundation of the park land during design storm conditions. However, use of the park land for pond storage plus carefully designed drainage systems should prevent the flooding from reaching nearshore roadways except under extreme storm conditions.

Overtopping rates were determined for the locally-preferred plan under a range of wave height/wave period/water level combinations selected from hindcast and measured storm conditions. A predictive model was developed using linear regression analysis with the Phase II data (Equation 7) that may be used to estimate overtopping rates for wave height/wave period/water level combinations within the ranges of parameters tested in these experiments.

Phase III experiments measured overtopping rates for cross-sectional configurations proposed for the portion of the Chicago Shoreline Project between Diversey Avenue and Fullerton Avenue. Experiments for Phase IV measured overtopping rates for the Chicago Shoreline Project in the vicinity of $57^{\text {th }}$ Street. An additional predictive model (Equation 18) was developed using linear regression analysis to incorporate the experiments of Phase IV with the experiments of Phase II that may be used to estimate overtopping rates for wave height/wave period/water level combinations within the range of parameters tested in these experiments. 



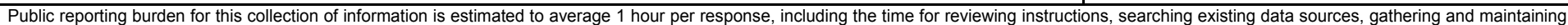

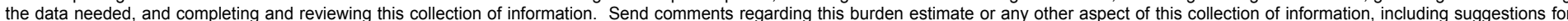

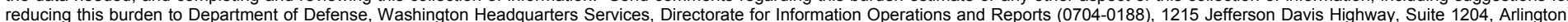

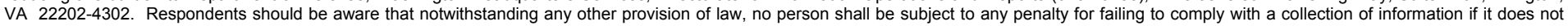
display a currently valid OMB control number. PLEASE DO NOT RETURN YOUR FORM TO THE ABOVE ADDRESS.

\begin{tabular}{c|c}
$\begin{array}{l}\text { 1. REPORT DATE (DD-MM-YYYY) } \\
\text { August } 2003\end{array}$ & $\begin{array}{c}\text { 2. REPORT TYPE } \\
\text { Final report }\end{array}$ \\
\hline
\end{tabular}

\section{TITLE AND SUBTITLE}

Overtopping Studies of a Stepped Revetment for City of Chicago, Illinois

3. DATES COVERED (From - To)

5a. CONTRACT NUMBER

5b. GRANT NUMBER

5c. PROGRAM ELEMENT NUMBER

\section{AUTHOR(S)}

\section{5d. PROJECT NUMBER}

Donald L. Ward

5e. TASK NUMBER

\section{5f. WORK UNIT NUMBER}

\section{PERFORMING ORGANIZATION NAME(S) AND ADDRESS(ES)}

8. PERFORMING ORGANIZATION REPORT NUMBER

U.S. Army Engineer Research and Development Center

Coastal and Hydraulics Laboratory

ERDC/CHL TR-03-X

3909 Halls Ferry Road

Vicksburg, MS 39180-6199

9. SPONSORING / MONITORING AGENCY NAME(S) AND ADDRESS(ES)

10. SPONSOR/MONITOR'S ACRONYM(S)

U.S. Army Corps of Engineers

Washington, DC 20314-1000

11. SPONSOR/MONITOR'S REPORT NUMBER(S)

\section{DISTRIBUTION / AVAILABILITY STATEMENT}

Approved for public release; distribution is unlimited.

\section{SUPPLEMENTARY NOTES}

\section{ABSTRACT}

Existing stepped-stone revetments along City of Chicago's Lake Michigan shoreline have deteriorated and are in need of replacement. Timber pilings supporting the revetments have decayed and contributed to the collapse of some of the stones in the revetment. The City of Chicago is interested in replacing the stepped-stone revetments with stepped concrete revetments. Physical model experiments were conducted at the U. S. Army Engineer Research and Development Center Coastal and Hydraulics Laboratory to aid in design of the stepped concrete revetment. The physical model experiments measured overtopping rates during design storm events for several proposed designs for the revetment. Parameters of interest included number and size of steps, elevation at crest, elevation at lakeward edge, and width of promenade.

\section{SUBJECT TERMS}

Revetment

Stepped

16. SECURITY CLASSIFICATION OF:

a. REPORT

UNCLASSIFIED

b. ABSTRACT
UNCLASSIFIED

c. THIS PAGE

UNCLASSIFIED

Lake Michigan

Chicago, Illinois
Overtopping

Physical model

\begin{tabular}{l|l|l|}
$\begin{array}{l}\text { 17. LIMITATION } \\
\text { OF ABSTRACT }\end{array}$ & $\begin{array}{l}\text { 18. NUMBER } \\
\text { OF PAGES }\end{array}$ & $\begin{array}{l}\text { 19a. NAME OF RESPONSIBLE } \\
\text { PERSON }\end{array}$ \\
\cline { 3 - 3 } & & $\begin{array}{l}\text { 19b. TELEPHONE NUMBER (include } \\
\text { area code) }\end{array}$ \\
& &
\end{tabular}


